DOE/EIA/8606-1

Vol. 1 of 2

Order No. 524

\title{
MASTER
}

$$
325 \text { exp for EIA STOEl }
$$

\section{The Impact of Petroleum Industry Horizontal Divestiture on the Coal Market}

\section{Volume I}

June 22, 1979

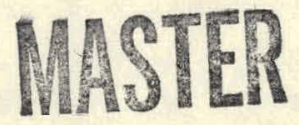

Prepared for:

U.S. Department of Energy

Energy Information Administration

Assistant Administrator for Applied Analysis

Under Contract No. EC-77-C-01-8606 


\section{DISCLAIMER}

This report was prepared as an account of work sponsored by an agency of the United States Government. Neither the United States Government nor any agency Thereof, nor any of their employees, makes any warranty, express or implied, or assumes any legal liability or responsibility for the accuracy, completeness, or usefulness of any information, apparatus, product, or process disclosed, or represents that its use would not infringe privately owned rights. Reference herein to any specific commercial product, process, or service by trade name, trademark, manufacturer, or otherwise does not necessarily constitute or imply its endorsement, recommendation, or favoring by the United States Government or any agency thereof. The views and opinions of authors expressed herein do not necessarily state or reflect those of the United States Government or any agency thereof. 


\section{DISCLAIMER}

Portions of this document may be illegible in electronic image products. Images are produced from the best available original document. 
Available from:

National Technical Information Service (NTIS)

U.S. Department of Commerce

5285 Port Royal Road

Springfield, VA 22161

Price:

Printed Copy: $\$ 8.00$

Microfiche: $\quad \$ 3.00$ 


\section{The Impact of Petroleum Industry Horizontal Divestiture on the Coal Market}

Volume I

June 22, 1979

Prepared by:

Donald L. Zimmerman, Lee H. Dymond, Robin L. Marris

Synergy, Inc.

Washington, D.C. 20009

Under Contract No. EC-77-C-01-8606

Prepared for:

U.S. Department of Energy

Energy Information Administration

Assistant Administrator for Applied Analysis

Regulatory and Competitive Analysis Division

Office of Energy Industry Analysis

Washington, D.C. 20461

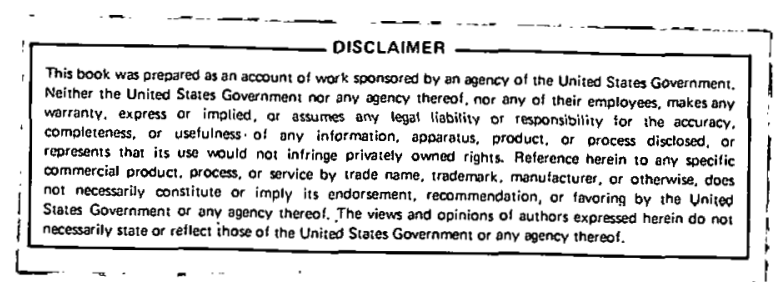


This report was prepared as an account of work sponsored by the United States Government. Neither the United States nor the United States Energy Information Administration, nor any of their employees, nor any of their contractors, subcontractors, or their employees, makes any warranty, expressed or implied, or assumes any legal liability or responsibility for the accuracy, completeness or usefulness of any information. apparatus, product or process disclosed, or represents that its use would not infringe privately owned rights.

Released for printing: October 9, 1979 


\section{PREFACE}

This paper is the final report under contract Number EC-77-C-01-8606, issued by the Department of Energy. The Contractor was Synergy, Inc., 2337 18th Street, N.W., Washington, D.C. 20009. The purpose of the study was to examine the effects on the supply and demand for coal of mandatory divestiture of petroleum producer-owned coal assets. The approach utilized a modification of the National Coal Model and the PIES Model of the Department of Energy.

The final report consists of several volumes. Volume I comprises two sections; the first contains the study methodology scenario development and results. The second section comprises a theoretical discussion of the economics of divestiture. Volume II is a technical appendix containing a discussion of the data, the computer algorithm's and their modification for this study. Volume III contains computer documentation and Volume IV embodies data on coal ownership which is proprietary in nature. Only Volumes I and II are publicly available.

The project was completed under the general supervision of Jerome Temchin, David L. Shapiro, and W. David Montgomery III. The Technical Project officer was Martin G. Taschdjian. 
Donald $\mathrm{z}$ immerman and Lee Dymond of Synergy, Inc., were the principal investigators, and Robin Marris of the University of Maryland provided support as sub-contractor.

Additional copies of this report are available from:

\author{
National Energy Information Center \\ 1726 M Street, N.W. \\ Room 850 \\ Washington, D.C. 20461 \\ (202) 634-5694
}


TABLE OF CONTENTS

COMPLETE REPORT

VOLUME

I .

II .

I I I.

IV.

V.

\section{TI TI.E}

\section{THE REPORT}

TECHNICAL APPENDICES

COMPUTER DOCUMENTATION

PROPRIETARY FTC SURVEY DATA

(Limited Circulation)

COMPLETE BOUND COMPUTER PRINTOUTS

(Limited Circulation) 


\section{TABLE OF CONTENTS}

VOLUME I

THE REPORT

SECTION 1

Page

EXECUTIVE SUMMARY . . . . . . . . . . . . . . i

CHAPTER 1-1 INTRODUCTION . . . . . . . . . . . . . 1-1

Study Objectives . . : . . . . . . . . . . . . 1-1

The Horizontal Divestiture Issue... . . . . 1-5

Legislative Scenarios. . . . . . . . . . . 1-7

The Report Outline... . . . . . . . . . 1-9

CHAPTER 1-2 STUDY METHODOLOGY, MODELS; AND UNDERLYING

ASSUMPTIONS . . . . . . . . . . . . . . . . . 1 111

Methodology . . . . . . . . . . . . . . . . $1-17$

The Models and their Relationship. . . . . . . 1-23

The Coal Supp1y Curves............. . 1-26

Project Independence Evaluation System (PIES). . 1-29

Assumptions ............... . . 1-34

National Coal Model Assumptions . . . . . . 1-35

PIES Assumptions . . . . . . . . . . . . . 1-37

Mode1 Modification Assumptions . . . . . . . 1-40

Caveats and Limitations. . . . . . . . . . . . 1-41

Confidence in the Study and Its Results . . . 1-45

CHAPTER 1-3 THEORETICAL ISSUES IN DIVESTITURE

ANALYSIS . . . . . . . . . . . . . . . . 1-47

CHAPTER 1-4 SCENARIO DEVELOPMENT AND IMPACT

EST IMATION. . . . . . . . . . . . . . . . . . . . . . 1-51

The Perturbation of the Variables. . . . . . 1-57

Verification Run of the Mode1 .......... $1-58$

CHAPTER 1-5 RESULTS . . . . . . . . . . . . . . 1-65

Results for the Adjusted PIES Baseline Runs. . 1-65.

The Total Divestiture Run...... . . . . . 1-79

The Restraint Scenario... . . . . . . . 1-85

Comparison of Scenarios... . . . . . . . 1-85

SECTION 2 (Separate Document)

CHAPTER 2-1 THE ECONOMICS OF DIVESTITURE. . . . . . 2-1

The Economic Implications of Legislative

Divestiture. . . . . . . . . . . . . . . . . . . 2-2

Implications of "Synergy". 


\title{
TABLE OF CONTENTS
}

(continued)

\author{
VOLUME I
}

SECTION 2 (continued)

Page

CHAPTER 2-2 THE INVESTMENT AND GROWTH BEHAVIOR OF SUCCESSOR COMPANIES COMPARED TO DIVESTED COMPANIES

COMPANIES . . ................ 2-17 The Theory of the Growth of the Firm Applied to the Divestiture Problem . . . . . . . 2-18

Optimal Depletion l'heory . . . . . . . . 2-25 Compotitive Fffects . . . . . . . . . . 2-33 Conclusions. . . . . . . . . . . . . 2-38 Bibliography 


\section{EXECUTIVE SUMM $\Lambda$ RY}

The U.S. Congress has set forth proposals which would prohibit oil companies from acquiring coal companies or other non-petroleum energy resources. Some proposals would require oil companies to divest themselves of any such resources that they already hold. The first legislation was introduced on this topic in the 94 th Congress and alternative proposals are under serious consideration at the current time. We have analyzed some major variants of these legislative proposals with a study of likely economic behavior in the coal market as a result of horizontal divestiture.

After a thorough study of the theoretical and empirical aspects of ownership-related behavior, two dichotomous sets of assumptions are possible.: One set of assumptions is oriented towards synergism and growth maximization. The interpretation of these assumptions in the model is one of a lower rate of return for oil owned coal assets relative to non-oil owned assets.

The second set of assumptions could broadiy be termed "monopoly" assumptions. The depiction of these within the model framework is one of higher rates of return for oil owned coal relative to non-oil owned. Both schools of thought have their supporters and detractors and studies can be found which seek empirical answers to these questions, usually with indeterminate results. The economics profession itself is divided on this question. It is our opinion that the evidence favors the lower 
rate of return on oil-owned coal assets.

Due to the controversial nature of the question, we have treated both cases as alternative baselines. As one might expect, the estimated impact of divestiture depends upon which baseline case one believes. Baseline 1 , synergy, leads one to a market impact of total divestiture of increased prices and lower production. However, the alternative monopoly baseline, Baseline 2, when used as a base to compare to total divestiture, yields a decrease in prices and an increase in production. The results for Baselines 1 and 2 and total divestiture are presented in Table 1 .

These results are based on economic theory, engineering and econometric models, and analysis; ail set in the general framework of comparative statics. Comparative statics is an analytical tool which permits investigation of a situation before and after government intervention.

The economic theory of the firm and its modern variants are used to establish the foundation for hypothesized behavior in the market before and after government intervention. The engineering and econometric models are used as a tool to establish a baseline case forecast in the absence of government action. Several alternative cases, based on perturbations of divestiturerepresenting variables, are developed and the model results compared to the baseline.

The models used include the National Coal Model and the Project Independence Evaluation System (PIES) model. These models are we 11 -grounded in economic theory and characterize the coal and energy markets well for analysis purposes. 


\section{TABLE 1}

\section{SUMMARY OF PRICE AND QUANTITY \\ FORECASTS FOR 1985 UNDER \\ ALTERNATIVE ASSUMPTIONS}

\begin{tabular}{|c|c|c|}
\hline Scenario & $\begin{array}{l}\text { 1985 Production } \\
\text { (Mil1ions of Short } \\
\text { Tons/Year) } \\
\end{array}$ & $\begin{array}{c}1985 \text { Industrial } \\
\text { Price } \\
(\$ / \text { Short Ton }) \\
\end{array}$ \\
\hline Baseline 1 & $1,029.7$ & $\$ 36.49$ \\
\hline Baseline 2 & $1,002.7$ & 39.03 \\
\hline Total Divestiture & $1,014.7$ & 38.56 \\
\hline
\end{tabular}


The Department of Energy has used these models extensively for othe analyses.

Data on coal mine and reserve ownership were required to allow for hypothesis testing regarding changes in ownershiprelated variables. Therefore, a unique methodology was developed to collect data, separate ownership, and modify the National Coal. Model. Our work on data and program modification is well documented. Because of the controversial nature of this study, we have also designed a system whereby analysts who disagree with the assumed behaviors, can re-run the model using their own assumptions. A11 the programs and data files necessary to do this are currently up and running on the DOE computer system. Volume III of this report, the Computer Documentation, explains this process in detail.

As with any study of this nature, there are caveats and possible weaknesses which should be ubserved. First, this study is not, and was not intendod to be, a complete cusl-benefit analysis of horizontal divestiture. Although it represents a major source of information on the market impacts, it does not address all costs. Comparative statics, while it is a powerful analytical tool, does not take into account thc adjustment mechanism nor the transactions costs involved. The process whereby the market adjusts to the government intervention may, in fact, contribute substantially to the total costs of horizontal divestiture. Practical experiences with forced divestiture in the Federal Government, such as Kennecott/Peabody, suggest that the transaction costs and adjustment costs of forced divestiture 
may be significant.

Second, a study using models and economic theory is necessarily based upon several assumptions. We have attempted to specify those assumptions in as great a detail as possible. As mentioned above, we have also designed a system whereby most of these assumptions do not constrain the use of the results. Anyone disagreeing with the assumptions can re-run the model and yieid results based upon their set of assumptions. It is necessary, however, that anyone using the results of this study be familiar with the assumptions underlying it:

Finally, this study is limited to the costs of divestiture between now and 1985. Therefore, the study has a mid-term perspective. The long-term implications appear to be inconclusive. 
VOLUME I

SECTION 1 


\section{CHAPTER 1}

\section{INTRODUCTION}

A current policy debate in the energy area focuses on the degree of control which the U.S. petroleum industry exerts over alternative fuel resources. Particular emphasis is given to oil company. penetration of the coal and uranium industries. This study focuses on oil company ownership of coal resources (operating firms and reserves) and specifically addresses the issue of the impacts on coal markets of horizontal divestiture-divestiture of coal company subsidiaries and coal resources by oil companies. Horizontal divestiture is viewed as a remedy for the perceived "evils" of increasing concentration of energy resources, and is developing into a major energy policy option. The Department of Energy (DOE) staff is charged with analyzing the major impacts of various horizontal divestiture proposals on coal markets. This study is part of a broader objective to develop a complete set of analyses regarding the effects of divestiture.

Study Objectives

The primary objective of this study is to assess the likely impact of U.S. petroleum industry horizontal divestiture on the U.S. coal market. The analysis is designed to be analytical, objective, and as sophisticated (in considering the interrelationships of various energy fuels) as possible. 
It should be stated at the outset that the issues involved in the horizontal divestiture debate are complex. They surely transcend the realm of economics and weigh heavily on political and sociological tensions. A study which focuses on the economic issues alone cannot be expected ro produce-clear-cut-policy directives. We are certainly sensitive to these limitations in the present study.

An even more important issue concerning this study is the theoretical basis and empirical limitations that exist. Classical. economic theory has little to say about the impact of divestiture because that theory does not consider resource ownership important. Alternative theories of the firm, although more difficult to substantiate, do however, provide a basis for analysis of the divestiture problem.

The models used in this study are the rulmination of much research and development effort over many years. However, like al1 models whose function is to abstract from reality in an effort to simplify complex relationships, there are assumptions upon which the models are based that may not satisfy everyone's perception of oil company involvement in the coal industry.

The fact that the theory expounded here is not considered "conventional wisdom," and the model not perfectly reflective of industry structure or behavior, means that one's results and conclusions must be considered suggestive, not indicative, of public policy. This study does not claim to be tho definitive work on the impact of horizontal divestiture. It is one approach, when combined with the unique modeling system developed under this contract, which allows additional thought and research on 
this topic to be undertaken by DOE's staff of professionals. The nature of the problem and DOE's technical requirements as specified below led to Synergy's proposal for using a set of models as a foundation for the study. The diverse set of industry and market attributes specified by DOE could only be accommodated through the use of a consistent set of engineering and econometric models. However, given this approach, we considered it inappropriate to build a new set of models on a major scale considering the time and resources available. Nor was it considered necessary since other models, suitable for adaptation to the needs of this study, already existed.

The National Coal Model and the Project Independence Evaluation System (PIES) were proposed as the vehicles for developing quantitative estimates of the impact of horizontal divestiture. The use of these models was combined with additional data collection, judgment and analysis, and programming modifications to develop an integrated technical approach to the problem. The issues to be addressed and requirements to be met by this study, as specified by DOE, were:

- On the demand side, the model developed was to include a derived demand formulation reflecting the major uses of coal. The effects of substitute fuels, along with other critical exogenous variables, were aspects which have to be incorporated.

- Supply equations were to be cost-based and include planned and potential mine openings, so that characteristics such as mine ownership and capacity, coal quality, and mining 
conditions could be included. Relevant physical characteristics such as BTU content, sulfur content, seam widths, strip versus deep mining techniques, as well as institutional characteristics were mining legislation and environmental end-use constraints.

o Proposed divestiture legislation was to be reviewed and the economic impacts of such a policy on cual demand and supply delineated. The divestiture traits were to be specified in analytical and measurable forms in an explicit and justifiable framework.

o The divestiture representing variables must be altcred and the effects on equilibrium coal consumption determined. Sensitivity analyses were to be done to establish a bounded range of effects.

Syncrgy addressed and integrated into the study the basic requirements of the Department of Encrgy. The end result is an objective, analytical study of horizontal divestiture policies. The results are based upon economic theory and modeling terhniques. In addition to addressing the hnaic divestiturc question, however, Synergy developed a system and methodology where DOE analysts can analyze additional questions and future policy scenarius in more detail. Indeed, many competitive policy issues and questions can be dealt with analytically and in a fashion consistent with PIES and the National Coal Model under the system that Synergy developed. Although the primary result of this study is an analysis of the horizontal divestiture issue, 
Synergy developed a methodology which allows DOE to continue its analyses of. competitive questions in the coal industry within a modeling, scenario-oriented approach.

The Horizontal Divestiture Issue

Horizontal divestiture is a complex issue which may be separated into several sub-issues. These sub-issues are frequently shrouded in political considerations and value judgments. It is the intent of this study to take an objective approach to this problem based on positive economic analysis. As such, this study does not comment on the issue of oil company "bigness per se." We believe that analyses of economic issues separate from any political or normative concerns will clarify the debate on horizontal divestiture.

This study attempts to pool together, and apply to the problem, the requisite economic theory and, based on it, to develop empirical estimates of likely inputs under alternative scenarios. The collection of relevant theories and application of them to this problem has not been done in a systematic fashion prior to this study. An effort is undertaken to integrate separate but related parts of economic theory into a cohesive set of tools applicable to the horizontal divestiture issue and its objective analysis. This study also attempts to utilize the best data available on the coal industry and the most sophisticated engineering and econometric models to analyze the issue.

Much of the work in this study focused upon modifying the DOE models (PIES, National Coal Model) which existed at the time. The modification of these models required the collection of 
diverse data elements, the application of judgment; and innovative integration with other models through the development of several new computer programs. Once the models were modified, hypotheses and scenarios could be developed which were wellfounded in the body of economic theory and empirical work which was reviewed and synthesized for this study.

The main thrust and original intention of this study was to compare the relative impacts of a total divestiture situation and a non-divestiture situation. Therefore, most of the analysis and results which follow are based on comparing these two situations. Conclusions are drawn, however, in all four areas of divestiture and restraint since legislative proposals appear to relate variously to all four areas. Some of the analysis. related to the conclusions drawn for these four areas is necessarily based upon deductions from available data. A legitimate attempt is made to characterize each legislative concept as closely as possible in the model. While it would have been desirable to relate each concept to a unique model run, for technical reasons this turned out to be impractical. The total divestiture case conslusinns are basod primarily un mudel runs. 


\section{Legislative Scenarios}

There appear to be four major legislative proposals relating to horizontal divestiture which must be taken seriously at this time. Three of these proposals are embodied in Senate legislation while one appears likely to emerge from the Senate hearings. While individual bill numbers and the details of proposals change from time to time, there are four basic concepts involved in the various divestiture proposals. These four concepts can be defined by divestiture vs. restraint and by all oil companies vs. major oil companies only. The current and potential legislative proposals cover all four of these areas. These four concepts are summarized in.Table I-1. The individual corresponding legislative proposals are described in more detail in Appendix 5 .

As of May 1, 1978, the current status of these bills is as follows:

S. 977 has become H.R. 5146. The language in the House bill is essentially the same as in the Senate bill. H.R. 5146 has been placed on the calendar but has not been voted on. It came out of the Energy and Natural Resources Committee on July 25, 1977. S. 489 was introduced in the 94 th Congress and is currently not being considered. S. 1927 has been referred to the Senate Judiciary Committee and hearings were held in the Antitrust and Monopoiy Subcommittee in August 1977. No further. 
TABLE I -1

ALTERNATIVE LEGISLATIVE PROPOSALS

\begin{tabular}{|c|c|c|c|c|c|}
\hline \multirow[b]{2}{*}{ CONCEPT } & \multicolumn{4}{|c|}{ EFFECTS } & \multirow[b]{2}{*}{$\begin{array}{l}\text { CORRESPONDENCE } \\
\text { LEGISLAT IVE } \\
\text { PROPOSAL } \\
\end{array}$} \\
\hline & $\begin{array}{l}\mathrm{A} 11 \\
0 i 1 \\
\text { Cos. }\end{array}$ & $\begin{array}{l}\text { Major } \\
\text { Oi1 } \\
\text { Cos. } \\
\text { On1y } \\
\end{array}$ & $\begin{array}{l}\text { Existing } \\
\text { Holdings } \\
\text { Only }\end{array}$ & $\begin{array}{l}\text { Future } \\
\text { Acqui- } \\
\text { sitions }\end{array}$ & \\
\hline $\begin{array}{r}\text { Divestiture } \\
\text { (DT) }\end{array}$ & $\mathrm{X}$ & & $\mathrm{X}$ & $\mathrm{X}$ & Formerly S. 489 \\
\hline $\begin{array}{r}\text { bivestiture }- \text { Major } \\
\text { (DM) }\end{array}$ & & $\mathrm{x}$ & $\mathrm{x}$ & $\mathrm{x}$ & S. 1927 \\
\hline${ }_{(\mathrm{RT})}^{\text {Restraint }- \text { Total }}$ & $\mathrm{x}$ & & & $\mathrm{x}$ & Potential \\
\hline $\begin{array}{c}\text { Restraint }- \text { Major } \\
(\mathrm{RM})\end{array}$ & & $\mathrm{x}$ & & $\mathrm{X}$ & $\begin{array}{l}\text { H.R. } 5146 \\
\text { (Formerly }\end{array}$ \\
\hline
\end{tabular}


action has been taken. The total restraint concept may be the result of hearings held by the Subcommittee in the Spring of 1978 .

The Report Outline

The issues, methodologies, and results summarized above are explained in detail in the rest of this report and its various appendices. Volume $I$ of this report is divided into two sections-Section 1 and Section 2. Section 1 explains the methodology, model changes and results of the PIES runs and serves as the basic presentation of the way in which the study was done. Section 2 of Volume. I is a moredetailed theoretical analysis of the horizontal divestiture issue. Chapter $1-2$ presents the study methodology and underlying assumptions upon which this study is based. This chapter and its referenced appendices document in great detail each step undertaken to properly develop, supplement, and alter available data used in this study. Caveats and suspected biases are also discussed.

Chapter 1-3 provides a brief description of the theoretical background underlying the specific model perturbations. Chapter. 1-4 presents the scenarios which were developed based on legislative proposals. The framework in which impacts and comparisons between these scenarios are made is also discussed.

Final1y, in Section 1, Chapter $1-5$ presents the results of this study: It is important to note that no direct policy conclusions are drawn here. We only specify the results and any implications must be viewed in a broader context consistent with the other areas of analyses on the divestiture issue. 
Section 2 of Volume $I$ is divided into two parts which provide a more detailed theoretical analysis of the issue of horizontal divestiture. These two parts attempt to place the issue of horizontal divestiture within the proper context in the theory of the firm, while at the same time maintaining a consistency with the realities of the diversification of oil companies into the coal industry. The analysis of Secliun 2 also focuses upon optimal depletion theory and the impacts of divestiture an depletion of coal resources.

Other volumes of this report, especially Volume II, Technical Appendices, are provided for detailed substantiation of the technical aspects of data manipulation and model development. 


\section{CHAPTER 1 - 2}

STUDY METHODOLOGY, MODELS, AND UNDERLYING ASSUIPTIONS

The sections in this Chapter describe the general approach taken, the specific methodology and models used, and the assumptions underlying the study. Individual parts of the specific methodology, especially the model modification process, are further documented in referenced appendices.

General Approach

This study is based on an analytical technique named "comparative statics." This type of analysis allows explicit comparison of the situation without intervention and with intervention. It also allows comparison of alternative scenarios, each against the same base or reference point.

Specifically, we are interested in analyzing the impact of horizontal divestiture on coal markets through comparison of equilibrium prices and quantities in 1985. These quantitative market equilibrium results are developed. for the baseline and alternative scenarios. This technique is illustrated graphically through a conceptual supply and demand framework in Pigure I-I, which reflects three different periods in the comparative statics approach.

In the process of employing the comparative statics technique, forccasts must he made of the future. The basic reference point for the study is the baseline forecast. A baseline forecast assumes that past trends and relationships will continue in the 
FIGURE I - 1

GRAPHICAL ILLUSTRATION OF

COMPARATIVE STATIC ANALYSIS FOR

U.S. COAL IN 1985*

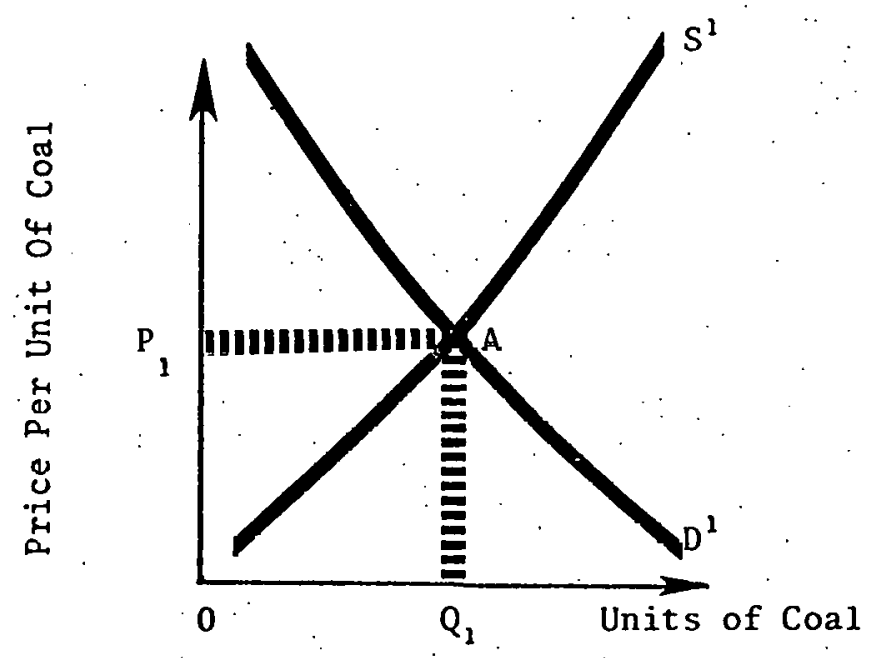

PERIÜU 1

(Baseline)

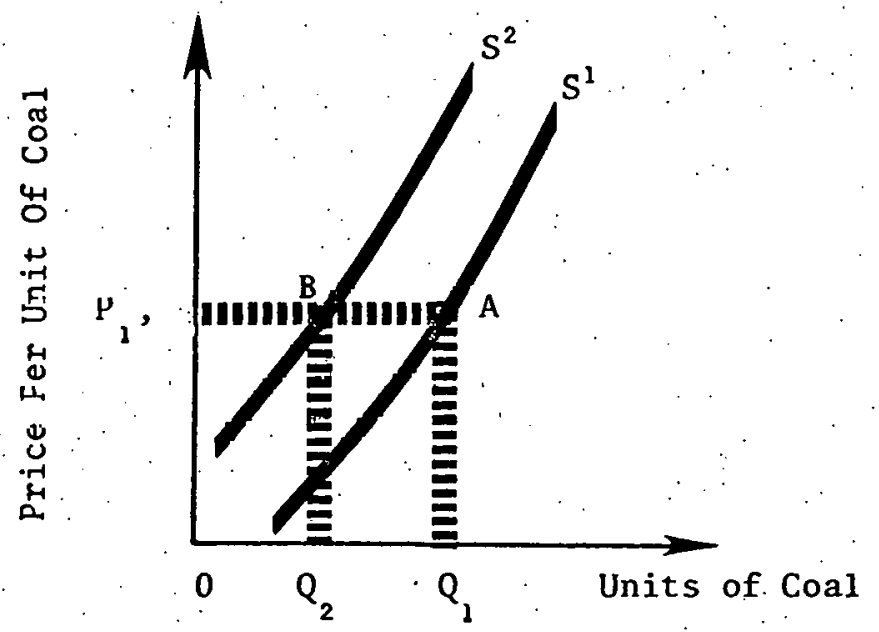

PERIOD 2

(F.xngenous

Supply Shift)

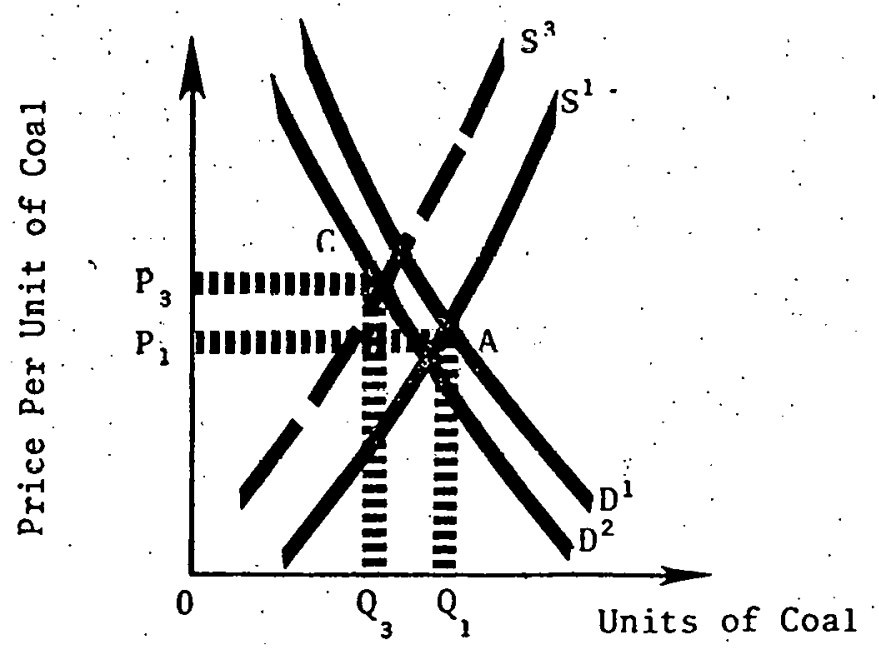

PERIOD 3

(Feedback and

Equilibrium)

* The curves shown here are not based on actual data. 
future. Therefore, it is a reference point, or benchmark, indicating the situation which would occur in the absence of mandated horizontal divestiture. Legislative proposals which would. cause different effects in the future can then be compared to the baseline forecast.

Baseline forecasts are always made utilizing several underlying assumptions. The assumptions should be explicitly identified to enable individuals to fully assess the results of the study: These assumptions are specified in later sections of this report. We begin in Period 1 with the supply and demand curves $S_{1}$ and $S_{2}$ which exist in the adjusted baseline case. Simplistically, a supply curve is defined as those quantities which would be forthcoming at various prices. Similarly, a demand curve is defined as those quantities which would be demanded at various prices. These two curves are schedules of price/quantity combinations. The supply and demand schedules intersect at point A. This defines the market-clearing price and quantity $\left(P_{1}\right.$ and $\left.Q_{1}\right)$ at which supply and demand are in equilibrium.

While conceptually we can speak of curves, in the application of this analysis to the modeling environment we are really observing points on a curve. These curves actually exist for various price/quantity combinations within the modeling framework. However, the graphic depictions in this section may not show the exact shape of the curve on either side of those points.

Period 2 shows the supply shift (from $S^{1}$ to $s^{2}$ ) which is the direct result of a perturbation in a divestiture-representing. variable. This variable change is based upon economic theory 
and the particular scenario being run. All of the initial perturbations of variables occur on the supply side in this analysis. Horizontal divestiture, based upon this study, is primarily a policy which impacts on supply. The demand implications are exclusively on a feedback basis from the supply shifts. The shift of the supply schedules is shown in the Period 2 diagram as an example of some divestiture variable change which has the initial effect of reducing the supply (from $Q_{1}$ to $Q_{2}$ ) for any given price. One could also state that the same quantity of coal would now have a higher price in Period 2, relative to Period 1.

We begin Period 3 with an exogenous supply shift which the market reacts to with a demand shift (from $\mathrm{D}^{1}$ to $\mathrm{D}^{2}$ ). This represents the feedback effects on demand as a result of the supply shift. An equilibrating process is employed to converge on a new equilibrium price and quantity. In the process, there is a new supply shift to $\mathrm{s}^{3}$. (Actually, we do not observe all of the $\mathrm{S}^{3}$ curve; rather, we observe the new equilibrium point $C$ which we know is not on $\mathrm{s}^{2}$ ). The new interaction of demand and supply is at Point $C$ with a corresponding new price of $\mathrm{P}_{3}$ and new quantity of $Q_{3}$. For the purposes of this study, we are interested in comparing $P_{1}$ and $Q_{1}$ to $P_{3}$ and $Q_{3}$.

There is a direct correspondence between our methodology and this three-period conceptualization. Period 1 represents our baseline PIES run with all its underlying data collection, model modification, and assumptions embodied in it. Period 2 corresponds to the situation where we perturb a Coal Supply Model variable; re-run the model, and produce..a new set of supply curves. Period. 3 is the new equilibrium PIES solution based upon a re-running of PIES with the shifted supply curves as a new input. 
It should be noted that every attempt has been made to develop forecasts, for both the baseline and the alternatives scenarios, which are correct in an absolute sense. That is, the numbers which are forecast for 1985 under each alternative scenario are the best ones available based on current information and the underlying. structure and assumptions. However, the relative impacts are more important than the absolute values. Because of the structure of this study one can place more confidence in the relative impacts since the comparison is between alternative scenarios; each to the baseline case. This methodology has the desirable property that it standardizes, or normalizes, the underlying results. Therefore, the relationship between the baseline and any one scenario can be evaluated relative to the relationship of the baseline to another scenario. Therefore, in ranking the various legislative proposals in terms of their impacts, one should place more emphasis on the ordinal ranking of these impacts.

In addition to the comparative statics approach, the analysis and results are embedded in a model framework. The modeling format is appropriate for this study for a number of reasons. First, it was important that the results be embedded in a modeling framework allowing for equilibrium coal consumption solutions. To accomplish this, rather sophisticated engineering and econometric models of the coal and substitute fuel sectors are required. In the time and with the resources available, these models could not be built de novo. 
Further, a new model might not have been necessary or desirable if resources were available. The Department of Energy has spent several years and substantial resources to build several "stateof-the-art" models. Those models, which are primarily econometric ones based on engineering estimates, were developed and improved over: a long period of time and they still should not be viewed as perfect. However, they have been used as a basis for a large number of analytical and policy studies within and outside of DOE. While improvements can still be suggested, they have stood up well to critical scrutiny.

Thcse models are well-suited for the purposes. of this study: They are available and they do portray the markets by containing a large amount of information and relating it to other sources of information. The results of this study, as ing as the assumptions, changes; and modifications are clearly defined, can be used in a consistent fashion with other analyses based on these models. This result is useful, not only for the study of the issue of horizontal divestiture, but also for other analyses in the area of competition and coal.

We have attempted to develop a system whereby the model framework we have used, and the ownership modifications we liave built in, will alluw DOE analysts to have a capability to use the National Coal Model and PIES. We have taken extra measures along the way to thoroughly document each step of our procedure and to try and train DOE analysts to use this as a tool. This system approach has a further advantage in that it is very flexible. If some major change in energy markets occurs in six months which could not 
have been forecast in this study, the modification can be made to the model and all of the results re-run and re-evaluated easily. Other scenarios which DOE staff members develop can be tested quickly and conveniently.

Finally, the issue of horizontal divestiture is especially controversial. We feel that the use of engineering and econometric models in the fashion which we have used them can lend credibility and objectivity to this type of issue.

\section{Methodology}

The methodology which evolved from the above philosophies and constraints allows us to use structural models for simulation of horizontal divestiture policies. This methodology was developed in conjunction with DOE personnel. Much of the work involved was experimental and a large number of innovations were required at each step. A brief step-by-step summary of the methodology follows:

A. Collect data on coal production and reserves based on ownership.

B. Modify the supply model side of the National Coal Model and its input datá base to allow. for the explicit introduction of ownership as a new dimension.

C. Run the Coal Model to produce two sets of supp1y curves: oil-owned coal, and non-oilowned coal.

D. Develop and implement a computer program to merge the two sets of supply curves in fashion consistent with downstream uses of the data set. 
E. Compress the resulting supply curves from 192 coal type/region supply curves into 50 supply curves which can be read into PIES.

F. Run the supply curves through the PIES coal preprocessor and main models.

G. Develop an initial set of scenarios and hypotheses regarding horizontal divestiture which can be tested using the Coal Model.

H. Change assumptions, initial values, etc. in the Coal Supply Mode1 to represent each of the specified scenarios or hypotheses.

I. Run the modcls for each hypothesis lo generate a new set of supply curves and a new PIES run.

J. Compane the baseline case to the alternative scenarios and perform a comparative static analysis of the results.

These individual steps are discussed in more detail below. A. It was necessary in the analysis to be able to identify ownership of reserves. Without this basic information integrated in the model, it would have been difficult to study the issue of horizontal divestiture using the econometric franework. The first step in that process was to. collect additional data on coal production and ownership of reserves. This information was collected from a number of sources and judgmental, decisions also made where gaps exist.

It was necessary to have information on the various types of coal and the specific locations of the coal reserves nwned by nil companies. These data were available in an incomplete form from publications of the Bureau of Mines (BOM), the FederaI Trade Commission (FTC), and the Keystone Coal Manual (Keystone).

The exact methodology pursued in assigning reserve to ownership categories is explained in Appendix 2. However, 
a brief step-by-step summary of that process is included below.

1. Identify coal companies owned by oil companies.

2. Identify the existing mines of these coal companies which are owned by oil companies.

3. Obtain information about each mine; such as produetion clase, life nf mine, and when opened.

4. Fill gaps in the data by applying judgment and decision rules.

5. Calculate needed reserves of all the oil companies' mines by state.

6. Determine coal reserves by company and by region based upon the FTC survey and Keystone data.

7. Separate, from total reserves owned by a company in a region, the amount tied up in production. The residual will represent reserves in that region for that company which are not currently in production.

8. Distribute those reserves among the states in the region.

The above process relies upon information obtained from Keystone, BOM, and the FTC survey and also relies upon judgmental decisions which were necessarily made during the process of developing the data set. Many problems which existed with the data and decision rules have been explicitly stated in Appendix 2 .

B. The Coal Model and input data base were modified to allow for the explicit introduction of ownership as a new dimension in the model. This particular step required some assistance from the Office of Coal Analysis in DOE. The current input data base was split into two input data bases: one reflecting reserves owned by oil interests, the other reflecting non-oil-owned reserves. 
C. Once the above changes were made, two sets of supply curves were generated. This step involved running the Coal Model once for each input data base. Each of these sets of supply curves represents the supply which would be forthcoming at various priccs for each of 192 coal type/region pairs. One set is based upon coal available from oil-owned assets only; while the other is based on coal available from non-oil sources.

D. A computer program was written to merge, sort, and identify, the oil and non-oil supply rurves. This is a four hundred line program written in FORTRAN and currently. operates on DOE's computer system. The program is fully documented, and a listing of it is provided in the volumc of this lepurt entitled Computer Documentation. The associated control program and instructions for runing it are also included in that volume.

lhe product of this program is a new set of supply curves representing a mix of observations of oil-uwned and non-oil-owncd mines. These supply curves are conceptually identical to the ones produced before the separation of ownership task was undertaken. However, the new supply curves allow for identification of oilowned versus non oil-owned coal assets. Because the supply curves are based on input data which are separable by ownership, differential characteristics can be applied to the two set.s nf data and the assumptions related to each. These assumptions which can be changed include rate of return, wages, and cost of capital and uther economic variables.

E. The above merged supply curve data set was built with the additional constraint that it must be compatible with PIES. Therefore, the merged data set was run through a compression program 
written in GAMMA. The resulting supply observations represent 50 supply curves. These curves are consistent with PIES and are essentially summations of various coal types and regions. F. Once this set of curves has been generated the PIES Access group within DOE can run these curves through the coal preprocessor and the main PIES models. This step of the procedure was done entirely by. DOE personnel. The resulting PIES "Wonder Cookie" reports were checked by them for gross errors or inconsistencies and given to us for interpretation and analysis.

G. Those scenarios and hypotheses regarding horizontal divestiture which we wished to test using the models were developed. Two steps were involved in this process. The first one was to identify those scenarios and hypotheses based upon theoretical and empirical arguments founded in economics. The scenarios had to be based upon the most likely legislative policy prescriptions.

The second part of the process involved the representation of these hypotheses and scenarios in the context and framework of the models. This representation aspect was an important step which effectirely constrained the number and types of hypotheses which could be tested.

H. Once it had been determined what should be changed in the model, these changes were carried out. The changes involved changing variable assumptions and re-running the series: of models. necessary to arrive at the end result which was a PIES run. A list of variables which were potentially available for change in 
the models is available in Volume III. A new set of changes was required to represent each new hypothesis or scenario.

I. Once the changes were made, the series of models were run again in the same fashion as produced the first set of supply curves. The new sets of supply curves represent the situation which would obtain if the hypotheses which we have developed and structured within the model come to pass. At the completion of this step, onc baseline set of results and several other sets of rcsults were available.

J. At this step in the project, we were in a position to perform a comparativc static analysis of these results. We ultimately wanted to compare two situations. The first situation was a forecast of coal consumption and prices in the absence of horizontal divestiture legislation. The second situation was une in which some form of horizontal divestiture legislation has been passed and tliere had been some effect on the price ur quantity of coal becase of this 1 aw. Once these two situations were modeled and run, the two outputs were used to interpret the results based upon the scenarios run,

The next sections provido an overview description of the two major models to be used in this study. Volume II of this report, the Techniral Appendices, provides further specific details relating to these mode1s. 
The Models And Their Relationship

The Department of Energy has been at the forefront of the movement by government agencies to use econometric models for policy evaluation. Since 1974, large amounts of resources have been committed to the development and use of these models. The PIES model as described below represents the prime example of this developmental work. However, a great deal of effort has gone into the satellite fuel models which feed into the PIES model and are considered by some to be a part of the PIES model. The National Coal Model is a DOE model which stands alone and is used for analysis of coal policies. However, the supply portion of the model is also used as an input into PIES. This section concentrates on the Coal Supply Model (which is the supply side of the NCM) since the changes that have been identified thus far all enter from the supply side. The Coal Supply Model is the satellite model which must be changed in order to run policy scenarios either through the National Coal Model or through the PIES model.

The Coal Supply Model generates approximately 190 supply curves based upon a state level breakout of reserves and 40 different coal types. Four of the heaviest coal producing states are divided up into two regions. Once these supply curves have been generated, they can be used as input into the National Coal Model or as input into PIES. If they are used as input into PIES, they must be run through a compression program which will aggregate the Coal Supply Model regions into the PIES supply regions. Figure $I-2$ shows a simple schematic of the relationship between the various coal models. 
FIGURE I - 2

RELATIONSHIP OP COAL MODELS

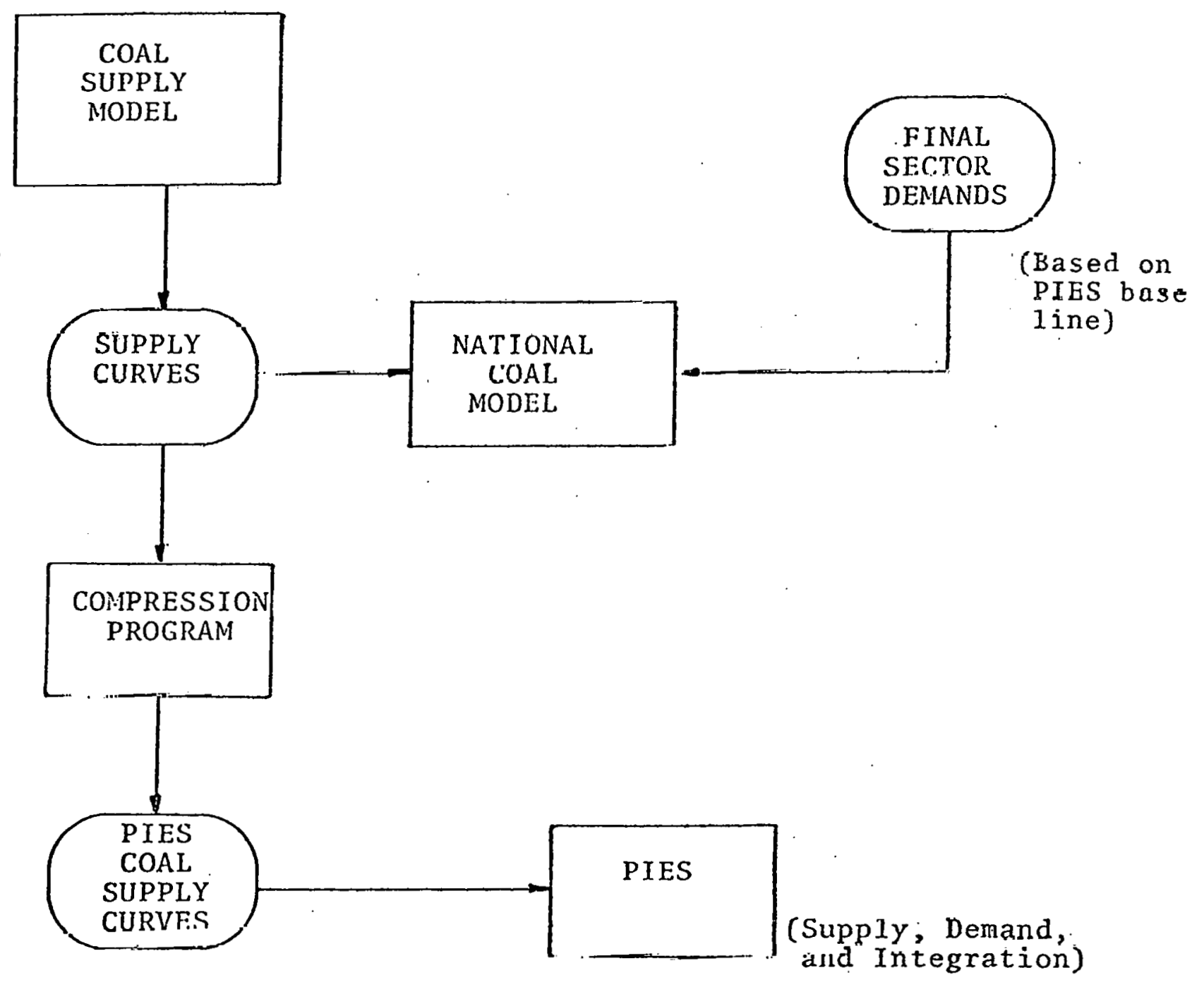


The methodology does not utilize the demand sector of the National Coal Model which, as an entity, includes the Coal Supply Model. We have not analyzed the demand side and integrative mechanism used in the National Coal Model since they were not employed.

The coal supply curves generated by the model are cost-based and take into account the relevant physical characteristics of coa1. The following is a point summary of the methodology used to generate the coal supply curves. I/

1. Begin with BOM's demonstrated reserve base estimates of coal tonnage and quality characteristics by seam and county,

2. Assign reserves to coal supply regions,

3. Assign reserves within each region to product classes,

4. Eliminate negligible reserves,

5. Estimate existing mine production and reserves committed to existing production,

6. Allocate uncommitted strippable reserves to overburden ratio categories,

7. Allocate uncommitted deep reserves to seam thickness and seam depth categories,

8. Allocate uncommitted reserves to mine size categories,

9. Assign production estimates to mine-types,

10. Estimate minimum acceptable selling price for each mine type,

11. Arrange mine types with associated production levels in order of minimum acceptable selling prices.

Each of the above points are explained in detail in Appendix 1 of Volume II.

1/ This sinnmary of the methodology is taken from the FEA document, Coal Supply Analysis, May 1976. This point-by-point summary refers to the general methodology and is still correct even though modifications have been made since the time that document was pub1ished. 
The Coal Supply Curves

The supply curves generated by the Coal Supply Model are representations of the potential production levels available, at various prices, of a given type of coal in a given region. Figure $\mathrm{I}-3$ is an illustrative example of one coal supply curve for one region and coal type pair. This supply curve is a multi-stepped function where each step represents a different inine type. The height of each step represents the minimum acceptable selling price for that particular mine type. The length of each step represents the maximum annual production that the demonstrated reserve base could sustain from that particular mine type for 20 years.

Included in the supply curves are two kinds of production. The first kind of production is from existing mines and would be represented in the first steps of the supply curve. The other kind of production is potential production from new mines. The minimum acceptable selling prices represent a price which is based upon operating costs plus a recovery of and return on invested capital. For those mines already in production, the minimum acceptable selling price will be relatively lower because mines which are already open have sunk capital and will rationally operate as long as they can cover variable cost. For new mines, the necessary capital will only be invested if there is an adequate rate of return on investment.

The type of supply curve generated by this model assumes that the reserves will be developed first which are attached to the least costly mines. That is, within the same geographical 
FIGURE I - 3

prjute

EXAMPLE OF COAL SUPPLY CURVE

(s/lion) FOR ONE REGION/COAL TYPE

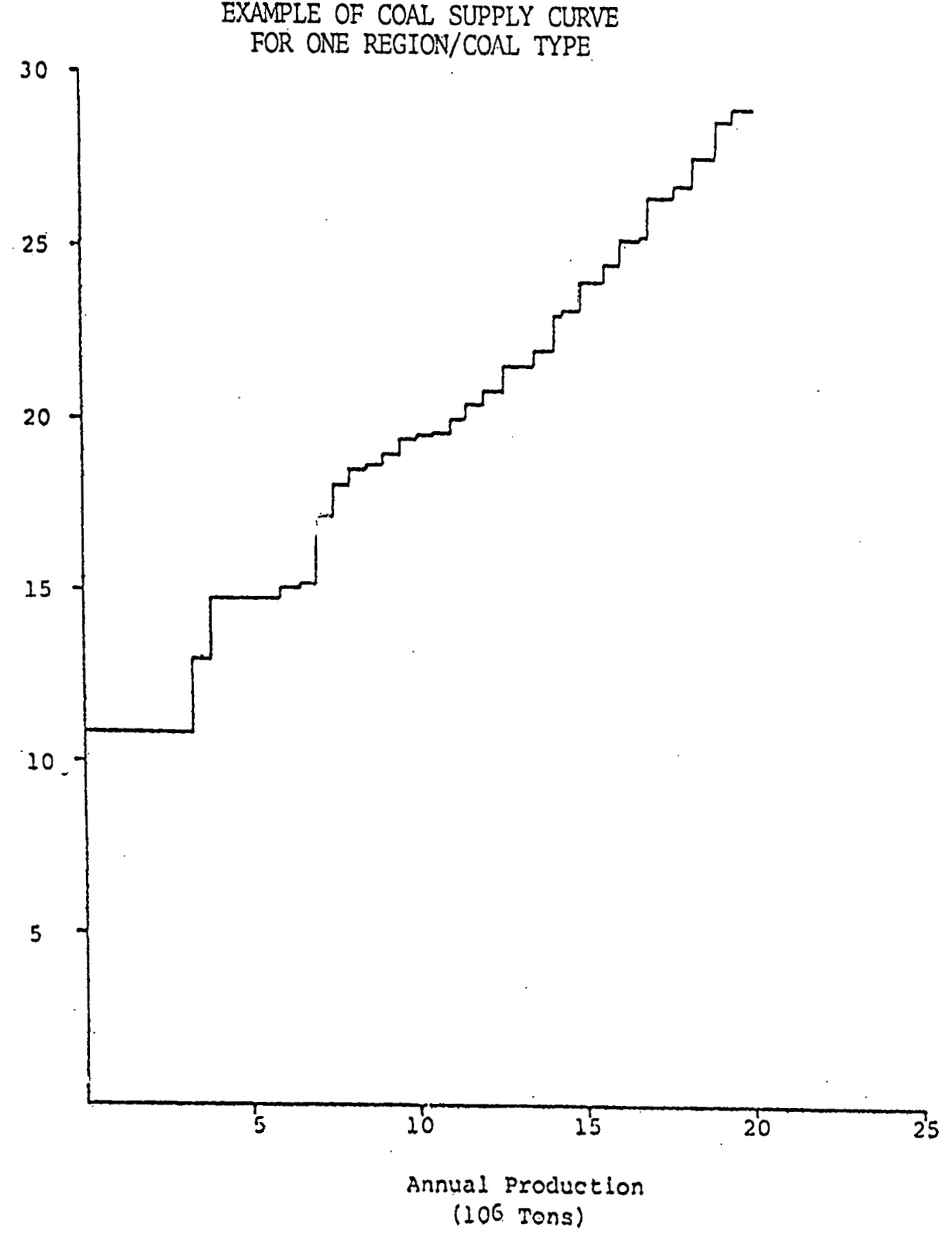


area, for reserves of the same quality, they will be developed in order of mining cost. The assumption implies that in the long run, the coal industry is reasonably competitive and efficient. This is not to indicate that market imperfections do not exist. Short-term imbalances between supply and demand are possible and have occurred in past periods such as 1974 . The price of coal, however, in the long run does appear to be cost-based in the sense that long-run contracts generally reflect costs of production.

'Ihese supply curves also have the assumption embedded in. them that no major new technologies will be developed in the time period before 1990. This is not to say that new technolo. gies will not be developed, but they will not be in widespread commercial use during the time period mentioned. Therefore, the mine types shown here are based upon current technology for mining cool. The costs are also based upon current factor costs and productivity although there is a degree of flexibility for change within the model.

This "fixed technology" assumption is not especially restrictive for the problem at hand. The reason for this is that sevcral years of testing (probably at least five) would be required before major changes in mining systems would be widely adapted for new mines. Assuming that the current develnpment period of four to seven years persists, new technologies would not be present in new mines until a period after 1.985. If the perind betwoen 1985 ald 1990 were to be analyzed, adjustments would be necessary. New technologies would start to be in 
widespread commercial use during this time period. Since we are interested in analysing the period between 1980 and 1985, this does not present a problem. There are other assumptions which are explicitly in the model which are specified in a later section.

Project Independence Evaluation System (PIES)

The Project Independence Evaluation System (PIES) is a complex, integrated, modularized computer model developed by the FEA, now DOE, to analyze energy policy. The model predicts the state of the energy sector of the U.S. economy in 1985 and 1990. The relationship of satellite models, such as the Coal Supply Model and PIES, is presented. in Figure I-4.

For each of the ten DOE energy regions, for the commercial, industrial, residential, transportation, and minor fuels sectors, PIES determines supply and demand equilibrium for the foliowing fue1s:

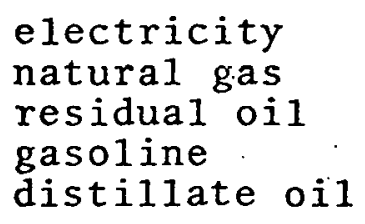

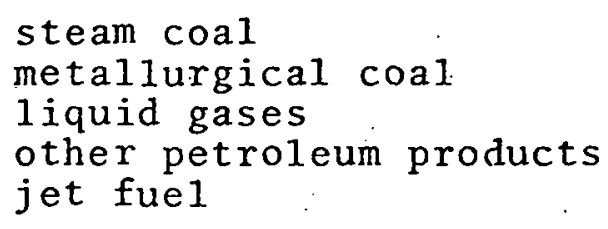

PIES determines the sources of these fuels, the methods of conversion for end-use consumption, and inter-regional transfers of fuels necessary for final supply-demand equilibrium. PIES. also delails import requirements for 19 crude types and seven oil products.

The PIES model is composed of three different model systems: a collection of econometric models which predict demands for each fuel by sector, by geographic region; a set of supply 


\author{
FIGURE $1-4$
}

\title{
RELATIONSHIPS OF PIES WITH SATELLITE MODELS
}

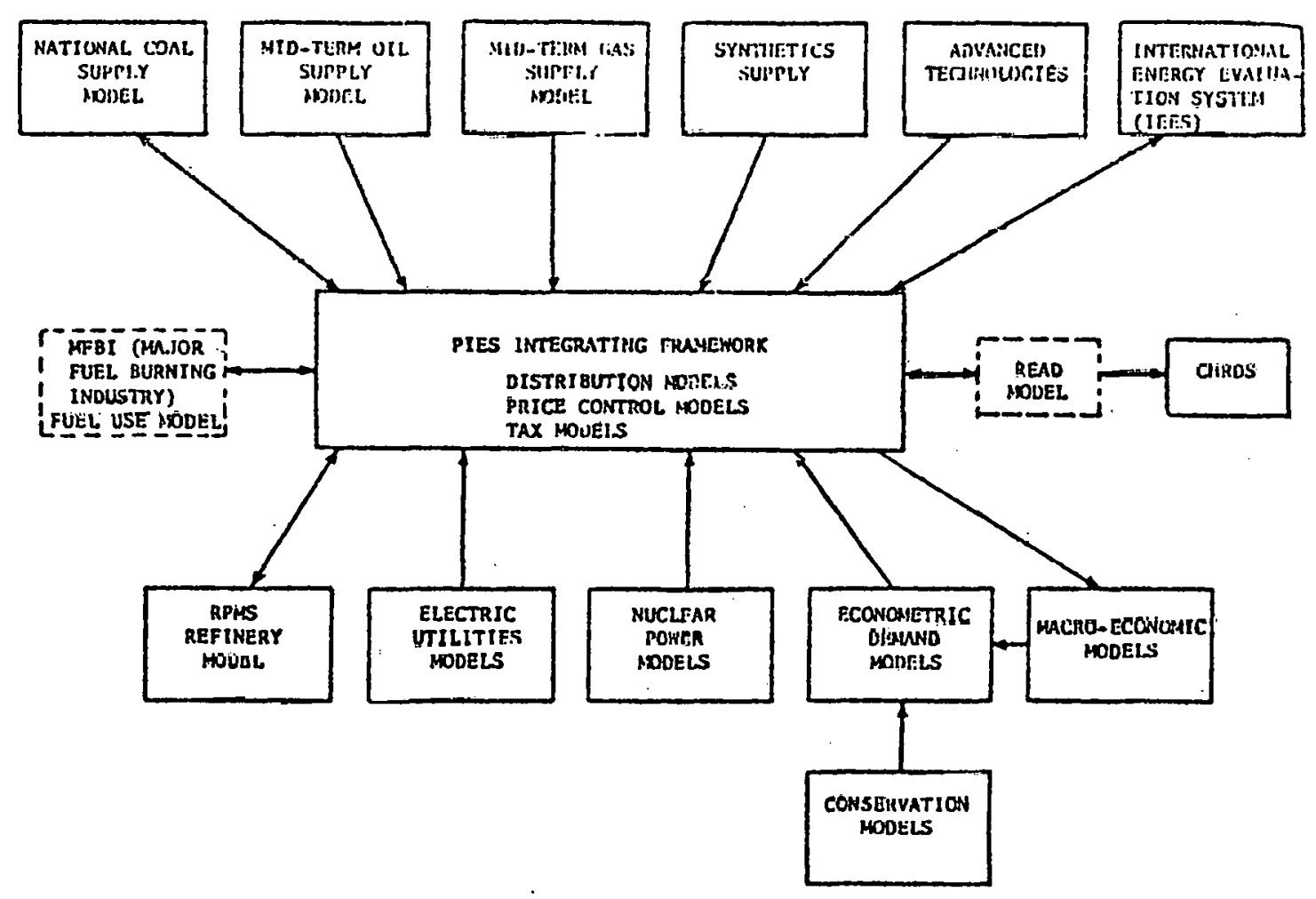

(Dashed boxes represent modols in tho process of dovolopaent.) 
representations--supply curves--for each fue1; and an integrating mechanism which solves, with the use of 1 inear-programming (LP), the partial equilibrium solutions. Below we briefly describe each of three segments of PIES, with a more detailed description to be found in Appendix 4.

The Regional Demand Forecasting Model (RDFOR) is a part of PIES and represents a set of demand equations which provide annual estimates of quantities demanded, prices, and price ana income elasticities of demand for 30 fuel/sector pairs for each of the ten DOE regions from 1977 to 1990. Fuel choices are price-sensitive, price induced substitution is uninhibited, and dynamic adjustments to changing fuel prices and economic conditions are incorporated into RDFOR.

Exogenously determined macro variable forecasts, parameters, and initial prices and quantities are combined within RDFOR to define points on a demand surface. Slopes and elasticities are determined through price perturbations of $10 \mathrm{~g}$-1inearly specified equations: DFACE, a Demand Interface Program transforms the output of RDFOR into a format suitable for use by PIES.

For residential, commercial, and industrial fuel demands; two equations are specified. The first relates the total use of fue 1 to other goods and services in the economy. The second analyzes the distribution of this total fuel demand between. different types of fue1s. Geometric distributed lags are used to extend the demand relationships to include dynamic adjustments. The demands for fuel in the transportation sector are modeled by end use. The major components of transportation fue1 demand 
are auto and non-auto highway gasoline fuel. Rail diesel fuel and commercial jet fuel are also determined within RDFOR.

Demands for natural gas, liquid gas, and coal in the raw materials sector, the commercial demand for asphalt and 1 iquid gas, industrial petroleum gases and metallurgical coal, and household/commercial demand for coal are modeled in a separate category. Except for the commercial demand for liquid gas, price is not an independent variable. Rather, demand is a function of industrial value added, time, and lagged consumption variables.

There are eight supply modules analyzed within PIES:

$\begin{array}{ll}\text { Coal } & \text { Utilities } \\ \text { Oil } & \text { Emerging Technology } \\ \text { Gas } & \text { Transportation } \\ \text { Refineries } & \text { Imports }\end{array}$

Representations of supply are constructed using production models based on corporate finance and operation's resedich techniques.

The coal, o11, and gas module are similar in design. The refilley llodule highlights the transportation and conversion of crude oil to final products by region of the country. The utilities module focuses on the building of new plants and the operation of new and existing plants, by region of the country. Capacity constraints for base, intermediate, and peak remand loads. are estimated and the average cost of eleclricity to the customer is calculated. Synthetics, nuclear fuel, and shale make up the emerging"technology module. Conversion, transportation, and necessary subsidies paid producers of expensive fuels are included in the analysis. Transportation supply includes: coal 
by barge and rail; natural gas by pipeline; crude oil, gasoline, and distillate by pipeline and barge; and residual oil by barge. The costs of the links between modes are carefully considered in the module.

The impact supply module takes bundles of crude oil as they arrive at refinery regions and prices them for transportation module use.

The Integrating Mechanism of PIES equilibrates supply and demand for each of the fuels considered and determines final prices and quantities sold. RDFOR provides estimates of prices, demands, and elasticities to the integrating mechanism. Step function approximation demand curves are constructed--each step indicating a range of quantities demanded at a specific price. Supply curves generated individually in their own modules are equilibrated to demand and equilibrium prices and quantities determined. If demand and supply are not equal at initial prices, the demand cruves are re-approximated with altered prices and the equilibration process is renewed. A final solution results when the difference between prices for two successive iterations is less than or equal to two percent, or 15 iterations have occurred. When supp1y equa1s demand, consumer's and producer's surplus is maximized and there is an optimal solution.

After initial demand curves are constructed, prices and quantities are adjusted to model natural gas regulation. Intertemporal consistency when calculating the amount of new utility and refinery capacity is also guaranteed through the dynamics of the model. Markups on electricity are also included in the integrating mechanism. 
There are several different scenarios which can be implcmented in PIES to reflect current and probable future policy considerations. Each scenario, along with changes in the price of imported oil, provides PIES with great flexibility in considering different states of the energy economy.

The impact portion of this report highlights the output of PIES. An output report begins with a listing of the supply modules, has a Table of Contents, and finally the output. Forecasts of aggregate quantities of distribution of supply to demand with selected growth rates from 1975 folluw. Except for oil, the quantities represcnt annud production or cousumprion. Oil and oil products are given in thousand barrels per calendar day. Following these fuantity tables are demand sector prices and marginal prices in demand, utility, and refinery regions.

\section{As sumptions}

Al1 analytical studies are neressaridy bascd upun explicit and implicit assumptions. Any complete evaluation of the results of such a study must take into account these assumptions. In the case of studies used as an analytical foundation for policy decisions, it is imperative that all assumptions be identified.

In this study, there are three broad elasses of underlying assumptions. First, there are those assumptions directly related to the individual scenarios. These assumptions will be sperified in detail in the next chapter of this report dealing with scenarios and impact estimation. Second, there is a set of assumptions related to the models used in this study, particularly the supply portion of the National Coal Model. Third, there are assumptions related to the methodology used to introduce ownership into the mode1s. 
National Coa1 Model Assumptions

The supply curves at the disaggregated level for both oilowned and non-oil-owned coal were generated by the supply side of the National Coal Model. The basic supply mechanism is embodied in the Reserve Allocation and Mine Costing (RAMC) Model.

There are several underlying assumptions related to the Model. Most of these assumptions are conceptual in nature and are related directly to the structure of the model. Therefore, they are implicit assumptions which cannot be changed without major alterations to the model. It is still important to identify the implicit assumptions, however.

The basic, conceptual assumptions underlying this supply analysis are as follows:

o It was assumed that the reserves of the same quality within a geographical area generally are developed in order of mining costs, i.e., the least costly to mine reserves are developed first. This assumption implies that the coal industry is reasonably competitive and efficient in the long run. Since the reserves of coal are vast and the ownership of coal reserves are widely distributed, no single produccr should be able to increase the cost of coal above actual costs (including a return on capital) of the marginal mine. Any attempt to increase the cost of coal above marginal mine costs would be undercut by other produccrs able to open new mines and still earn a market return on investment at the artificially established price. $3 /$

2/ These basic assumptions were taken directly from a report entit ted Coal Supply Analysis done for the, then, Federal Energy Administration, office of Coal, Nuclear and Electric Power Analysis, Washington, D.C. This study served as a foundation for the coal supply portion of the National Coal Model and was done by ICF, Inc. under contract No. C0-05-50198-00, May, 1976.

3/ Certainly, market imperfections exist and short-term imbalances between supply and demand are possible as demonstrated by the high spot market prices in 1974. However, the long-term contract prices appear to reflect production costs. Hence, coal from the last new mine to be opened should be priced at what it costs to produce the marginal ton rather than at a BTU equivalency with the next cheapest alternative fuel. 
- It was assumed that no significant change in coal mining technology will be in commercial use at a significant scale by 1990. The mine types used in the supply curves are based upon current mining technology. The costs for each mine type also are based upon current factor costs and productivity. Given that several years of testing (probabiy at least five) would be required before major changes in mining systems would be widely adopted for new mines and assuming that the current development period of four to seven years persists, the earliest we would expect new technologies to make an appearance in new mines would be between 1985 and 1988 .

- It was assumed that the cost of mining a ton of coal from a given reserve can be approximated knowing only two or three seam and mine characteristics. We estimated costs as functions of two factors for surface mines (overburden ratio and mine $s i z e)$ and three factors for deep mines (seam thickness, seam depth and mine size). Although these factors appear to be important, other geological considerations such as roof and floor conditions, gassiness and pitch of scam may be just as important. However, the cost functions that were employed could not be expanded to consider these other factors in the time available for the study. Indeed, the factors that were employed may have required pushing available data beyond its validity.

- It was assumed that step functions are good approximations of the long-term price/supply relation for coal. Iongterm coal supply curves conceptually are an attempt to quantify the relationship between the reserves that are in the ground and the costs and rates at which these reserves will be made available. The multi-step supply curve allows us to relate each price and associated production level to a specific mine type. The costs related to each mine type can be evaluated explicitly since the data and assumptions upon which they were based are presented in the section on methodology. Similarly, the data and assumptions upon which the production levels were based are presented in the section on methodology.

- It was assumed that well specified, multi-step coal supply curves adequately represent the supply function. Multi-step supply curves are logically sound since: (a) production costs will increase for deep and surface mines as the best reserves are depleted, (b) the model is allowed to determine the mix of mines on the basis of cost minimization rather than having the mix set exogenously based upon industry expertise. Second, only by making the data and assumptions that went into the curves explicit can reviewers comment intelligently on the curves. 
In addition to the above general assumptions, there are several specific assumptions regarding mine costs, wage rates, recovery factors, etc. which are detailed in appropriate appendices. Some of these economic variables are flexible enough to be changed quickly. As an example, the rate of return (ROR) can be changed from its assumed $8 \%$ to any other hypothesized value and the model can then be run to show the sensitivity of the results.

\section{PIES Assumptions}

The main underlying assumptions of the PIES model depend on the series of projections. The projections consist of six series labeled A, B, C, D, E, and F. Each. series differs in assumptions about domestic oil and gas supply, the general economic activities affecting energy demand and the world price of crude oil.

The series are as follows:

A. High supply, high demand, constant world oil price

B. Low supply, high demand, constant world oil price

C. Mid-supply, mid-demand, constant world oil price

D. High supply; 1 nw demand, constant world oil price

E. Low supply, low demand, constant world oil price

F. Mid-supp1y, mid-demand, 5\% annual increase of world oil price during 1980-1990

The range of oil and gas supply is derived froin low, mcdian, and high estimates of reserves taken from the U.S. Geological Survey (Circular 725) and appears in Table I-2 below. The range of economic variables affecting demand is derived from those forecasts from DRI:

CYCLELONG, TRENDLONG AND CEASPIRIT (Shown in Table I-3) 
TABLE I - 2

RANGE OF DOMESTIC OIL AND GAS SUPPLY

(Thousands of Barrels Per Day/Millions of Cubic Feet Per Day)

\begin{tabular}{|c|c|c|c|c|c|c|}
\hline & \multicolumn{2}{|c|}{ LOW } & \multicolumn{2}{|c|}{ MID } & \multicolumn{2}{|c|}{ HIGH * } \\
\hline & 1985 & 1990 & 1985 & 1990 & 1985 & 1990 \\
\hline Lower-48 On-Shore Oil & 5485 & 4084 & 5977 & 5108 & 6547 & 6662 \\
\hline $\begin{array}{l}\text { Outer Continental } \\
\text { Shelf Oil }\end{array}$ & 1000 & 938 & 1044 & 1014 & 1083 & 1079 \\
\hline Alaskan Oil & 1835 & 1856 & 1916 & 2352 & 1916 & 2381 \\
\hline $\begin{array}{c}\text { Shale \& Synthetic } \\
\text { Uil }\end{array}$ & 47 & 188 & 47 & 188 & 94 & 329 \\
\hline Total Oil & 8367 & 7066 & 8984 & 8662 & 9640 & 10451 \\
\hline Lower-48 On Shore Oil & 32416 & 26647 & 34997 & 32838 & 40679 & 35970 \\
\hline $\begin{array}{l}\text { Outer Continental } \\
\text { Shelf Gas }\end{array}$ & 7403 & 6677 & 7797 & 7603 & 7937 & 8189 \\
\hline Alaskan Gas & 2685 & 2997 & 3030 & 3890 & 3096 & 4342 \\
\hline Synthetic Gas & 2389 & 2374 & 2389 & 2734 & 2523 & 3315 \\
\hline Total Gas & 44893 & 39055 & 48213 & 47065 & 54235 & 51816 \\
\hline
\end{tabular}

${ }^{*}$ LOW $=95$ percent probability of recovery, MID $=50$ percent probability of recovery, $\mathrm{HIGH}=5$ percent probability of recuvery. 
TABLE $\mathrm{I}-3$

\section{MACROECONOMIC VALUES}

\begin{tabular}{|c|c|c|c|c|c|c|c|c|c|c|}
\hline & \multicolumn{3}{|c|}{$\begin{array}{l}\text { Gross } \\
\text { National } \\
\text { Product } \\
\text { (Bi11ions } \\
1978 \$ \text { ) }\end{array}$} & \multicolumn{3}{|c|}{$\begin{array}{c}\text { Industrial } \\
\text { Value } \\
\text { Added } \\
\text { (Bi11ions } \\
1978 \$ \text { ) }\end{array}$} & \multicolumn{3}{|c|}{$\begin{array}{l}\text { Real } \\
\text { (per capita) } \\
\text { Disposable } \\
\text { Income } \\
\text { (Thousands } \\
1978 \$ \text { ) }\end{array}$} & \multirow{2}{*}{$\begin{array}{l}\text { Popula- } \\
\text { tion } \\
\text { (Annual } \\
\text { Percent } \\
\text { Growth) } \\
\text { AIL }\end{array}$} \\
\hline & $\underline{\mathrm{HIGH}}$ & $\underline{\text { MID }}$ & LOW & HIGH & MID & LOW & $\mathrm{HIGH}$ & MID & LOW & \\
\hline 1985 & 2761 & 2715 & 2623 & 1093 & 1060 & 1022 & 8.1 & 8.0 & 7.8 & .87 \\
\hline 1990 & 3191 & 3159 & 2960 & 1320 & 1309 & 1191 & 9.0 & 9.1 & 8.6 & .90 \\
\hline
\end{tabular}

Other key assumptions for all the projection series are:

- Continued control of domestic crude oil prices and the entitlements program according to the Energy Policy and Conservation Act (EPCA);

- Continued regulation of the price, transportation tariffs and distribution priorities of natural gas sold to interstate pipeline companies according to Federal Energy Regulation Commission guidelines;

o Current Duter. Continental Shelf leasing schedules from the Department of Interior through 1981 and 4 sales annually of $\$ 300,000$ acres each thereafter. 
Mode1 Modification Assumptions

In the process of adapting the coal supply analysis for use in this study, it was necessary to introduce the concept of ownership in the model. Prior to this study, the concept of ownership had not been dealt with in the model. Therefore, much basic analysis and data gathering had to be undertaken and a complicated methodology developed to modify the model. This methodology, which was explained in detail above, was developed in conjunction with the Office of Coal Analysis at. the Department of Energy: There were a number of decision rules and assumptions which had to be developed and applied at each.. step of the methodology. Some of these assumptions and decision rules are based upon substantial analysis, while others are based primarily upon expert opinion and intuition from analysts. Some of these decision rulns and assumpliuns may be controversial, therefore, it is important to identify all of these. The assumptions arë summarized below. For a more detailed analysis, the reader is referenced to Appendix 2 , the Coal Supply Mode1 Modifications.

- The information contained in the 1.977 Keystone Industry Coal Manual is assumed to be accurate with regards to. coal production from mines and the ownership of operating coal companies by oil companies.

- $T L$ is assumed that needed or committed coal reserves are a function of annual production, expected life of the mines, and recovery factors. A discussion of these specific factors assumed is provided in the appendix on the modification methodology.

- It is assumed that the oil companies surveyed by the Federal Trade Commission and their reported demonstrated reserves are representative of the universe of demonstrated reserves owned by oil companies. 
- The oil companies have no coal reserves nor production in states other than those included in the model.

- The demonstrated coal reserves owned by oil companies were allocated to states based on information on location of production in Keystone and from information on lease ownership.

- In some cases it was necessary to assume that the demonstrated coal reserves with regards to sulfur/BTU categories, reflected the geological distribution that currently exists for each state.

- State committed reserves and production were categorized into sulfur/BTU groups using information from Keystone on the geological characteristics of coal seams unless direct information was given for each mine.

- Al1 current production by oil companies was classified as contract mine production.

Caveats and Limitations

Because of the nature of this study, there are a number of caveats which should be taken into account when utilizing the results of this study. First, it should be remembered that this study looks at one particular aspect namely, equilibrium price and quantity in the coal market. This is only one aspect of the horizontal divestiture impact: This study has tried to include some interpretation of the other costs involved. However, it should be remembered that this is not a total cost/benefit study on the issue of horizontal divestiture: The comparative static approach is a powerful one but ignores the process of adjustment from the old equilibrium to the new one. It also neglects thc time element associated with that adjustment process. The transaction cost of selling off resources as shown in a case approach to the divestiture issue would no doubt be significant. These costs must be included in a ful1scale cost/benefit evaluation. 
For that reason, the results of this study alone cannot be used as a recommendation for or against horizontal divestiture. The results of this study need to be used in conjunction with some estimates for each scenario of the costs of divesting and the costs of limited future investment in the industry.

Throughout this study we have been forced to make many decision rules and base analyses on less than perfect information than would be optimal. Under ideal conditions, each of the decision iules and methodologies would be based on detailed information as to the exact nature of any bias that may be introduced by them. Or, sensitivity analyses would be performed on every controversial or varying assumption in the study. Time and resources did not allow for either one of these options to be completely fulfilled. Decision rules and methodologies were based on the best available information at the time. If any rcsult appedrs to be particularly sensitive to any one of the decision rules they should be weighed rareful1y.

Our overall approach to forming decision rules has been to use the best data and judgment availahle and to insure that the decisions were consistent with our intuition. Using this guiding philosophy, it was hoped that the aggregate results for broad areas would be roughly consistent with other studies. While data for individual. states or individual coal types may be at variance. with other published estimates, our decision rules have resulted in what appcar to be reasunable results on a broad bas is.

In those cases where the decision rule was considered to be a potential major problem, analyses were conducted to determine 
the impact of choosing the decision rule. One example of this type of analysis concerns the allocation of reserves among states: The FTC reported reserves on the basis of USGS basins. This is basically a regional level of aggregation where several states are included in one basin. In order to use this information in the coal mode1, we needed the information on a state-by-state basis. We had planned to assign these regional reserves to states on the basis of production and lease information. This appeared to be the best method available given limited time and resources. There is some concern on DOE's part, and rightly so, that there was a chance that we were excluding states which have oilowned coal reserves because they don't have any production. It was agreed that this was possible and a small side analysis was launched to determine whether this was a large bias being introduced into the input cata.

'In gencral, because of the way in which the data was ultimately used in the coal model, this problem is not a large one. As long as the reserve information was roughly consistent on a regional basis, the major problem would be one state's reserves being assigned to another state. If one were interested in precisely defining each state's future production, this would be a more serious problem, however, the focus of the study was originally designed to be on a national level. At the request of DOE, we . looked into the problem further.

We investigated whether oil-owned new mines or oil-owned current mines with expansion plans existed in significant numbers in states we were not covering. The first step was to look at the 
Coal Mine Development and Expansion Survey published by Keystone. That survey 1 isted 21 states ( 23 regions) where new capacity was forecast to occur between 1976 and 1985. According to our data, based upon the above decision rule, 14 states (18 regions) were forecast to have oil company reserves available for development. Therefore, on a state basis, there were 7 states which we did not show oil reserves for which were to have new production during that period.

However, when one looks at these states, it appears not to be a problem. First, these states are very small coal producers, such as Maryland, Kansas, Tennessee, etc. The Keystone data show that, for these seven states, seventeen mines are projected to be opened. This is out of a total of 315 new mines in a11 21 states. Finally, on further inspection, none of these 17 mines are oilowned operations.

Therefore, in this particular example, our decision rule appeared to be fairly arbitrary, but nonetheless, was demonstrated to be proper for the way in which we were applying it. It must be emphasized that if these data are used in another study or in another fashion from the one in which we did, it may be inappropriate. However, for all but the most detailed state and coal type problems, it is our opinion that the data adequately represents ownership breakouts. One of our original objectives was to approximate the ownership breakout on as micro a level as possible. This has been achieved and this result is supported by the fact that, on a national level, our data appear to be roughly consistent with most other studies which have attempted to identify 
o.il ownership of coal. In the area of production, no one to our knowledge has used the methodology, we have used to identify ownership of specific categories of coal by oil companies according to operating mines and committed reserves. Again, we feel that the decision rules applied are reasonable and based on the lest information available.

Confidence in the Study and Its Results

In summarizing this chapter, we feel that the general approach used is a sound one and the best one available to answer the questions posed by DOE. We feel there are problems in the data, but that it is the best available. The modification process we have used may be somewhat controversial in some of its decision rules and judgments applied. However, it was based on the best information available and produced reasonable results.

While the results of this study appear to be valid, we do not group a1l aspects of the results into the same level of confidence category. It is important to try and estimate the level of confidence that a senior decision-maker could reasonably apply to the results.

The result which seems most likely to be correct in this study is the direction of impact. We are relatively confident that the directions of impact between the baselines with no intervention and the scenarios with some form of divestiture are correct. These directional shifts are supported by a large 
amount of economic theory, empiricism, and structured intuition.

Second, we trust the relative impact. That is, we trust the relative differences between prices and quantities between the baseline and other scenarios or between the other scenarios and themselves. We believe these are appropriate and adequate estimates, given the models which were used and the data available. However, one should place somewhut less confidence in them than in the pure directional change.

Finally, we would place the least confidence in the absolute forecast values, although they have value as working hypotheses. In this study we have been interested primarily in orders of magnitude, relative impacts, and broad directional changes. We have attempted to apply the best data and models possible to come up with a realistic forecast of the situation in the coal market with and without horizontal divestiture. However, because of the data and methndnlogy and limitcd time available, we feel that the absolute prices and quantities that we have derived should be scrutinized closely and used only as a working hypothesis. In general, the fnrerast prices and quantities under divcstiture or any of our scenarios should only be evaluated in relation to the baseline forecasts.

We have reported the results here in as much detail as possible, i.e., we have reported the direction, the magnitude of the change, and the point estimates. However, we have also attempted to estimate the confidence level of each one of these. 
CHAPTER $1-3$

THEORETICAL ISSUES IN DIVESTITURE ANALYSIS

Classical economic theory has little to say on the question of how divestiture will affect the conduct and performance of firms in a particular industry. The theory assumes that the behaviox of firms or industries is determined by conditions that transcend the motives that different types of firms might wish to pursue. An alternative group of theories of the firm, which may be referred to as discretionary or managerial theories, does provide some insights into the question of the impacts of divestiture. However, these alternative theories are based upon assumptions of firm goal pursuit which are sometimes difficult to substantiate empirically.. Therefore, one needs to make alternative assumptions about firm goal pursuit in order to evaluate different scenarios of possible responses to divestiture by firms in both the oil and coal industries. Assumptions also. need to be made about the business motivation and discretionary behavior of successor firms to divestiture.

We assume for the first scenario that oil companies have the necessary discretion to choose policies that.could differ significantly from those of successor companies. Oil companies may alșo possess different technological resources from successor companies and may be able to provide the means for transferring through direct investment into coal mining technology the expertise that they have acquired in their oil operations. Thus, there may exist some "synergy" between the technological, administrative and commercial functions of the oil and coal 
companies. In addition, oil companies, being in general very large, and operating under a financial posture that relies heavily on extensive cash holdings, may have access to larger and/or cheaper supplies of capital than successor companies might have. These assumptions imply that the behavior and performance of successor companies and divested coal companies would be different than in a non-divestiture situation. However, to rely upon synergistic potential and the loss of synergy as an unintended impact of divestiture requires one to forego the classic "tenet" of profit maximization.

Alternative theories of the firm, e.g., growth or sales maximization, suggest that diversification into an industry earning lower rates of return than might be earned in alternative investments at the present time, might bc in the best inlerest of the oil company stockholders. If we believe that the large oil companics, as firms, ale administrative organizations containing an association of commercial, managerial, and technological resources, then the analysis does not. fit. well in the regular neo-classical framework. This vicw of the firm is more in tune wilh managerialist or behaviorist outlooks.

Economic theory argues that a growth maximizing firm will grow faster for a given operating profit ratc and will display a lower reported profit rate than a firm maximizing stockholder welfare. Oil companies have made many acquisitions of firms with mediocre performance records. This acquisition behavior of oil firms is not inconsistent with an assumption of growth maximization. Under this assumption, oil companies might acquire 
coal companies whose reported profit rates were lower than the reported profit rates of other firms in other sectors of the economy.

Total divestiture would have the effect, assuming that the successor firm is not managerially motivated to the same degree that the oil company is, of raising the rate of return of the coal company formerly owned by the oil company. This would cause an increase in the price of coal and a reduction in the quantity available. The "synergy" and growth maximization assumptions are tested in the Coal Supply Model and PIES System by assuming that, before divestiture takes place, coal companies owned by oil interests have a rate of return of $3 \%$. After divestiture, that rate of return increases to $8 \%$ which is the rate of return for those coal companies not owned by oil interests. $1 /$ Capital and labor costs are also increased by $10 \%$ for oil-owned coal firms.

An alternative assumption or a factor working in the opposite direction would be any tendency of oil companies to reduce the competitiveness of the pricing process in the coal industry. This would be reflected in a higher rate of operating profit leading in turn to higher target returns and a general upward. shift in the industry supply curve. It would also have the secondary effect of causing faster depletion. This would be

1/ This process is described in more detail in Chapter 5 and the Technical Appendicies of Volume I"I. The 3\% figure represents a $5 \%$ perturbation in rate of return. The basic rate of return.changes reflect an arbitrary plus or minus 5 percentage point charge. 
represented in the Coal Supply Model and PIES Systems by assuming a pre-divestiture rate of return for coal companies owned by oil interests of $13 \%$ and a post-divestiture rate of return of $8 \%$ coincident with coal companies which are not owned by oil companies.

If the appropriate legislative scenario to be analyzed is one of "restraint" rather than total divestiture, then the monopolization theory has the effect of sustaining or erecting barriers to entry and thus entrenching the monopoly position-both for oil and non-oil-owned coal companies. We measure this impact by assuming a baseline of $3 \%$ rate of return for oil-owned coal companies and $8 \%$ for non-oil-owned coal companies and perturb these rates of return upward to $5 \%$ and $10 \%$ for $0 i 1$ and non-oil-owned coal companies, respectively.

Section 2 of this volume contains two parts which set out in a more rigorous manner the relationship between economic theories of the firm and the problem of horizontal divestiture. Included is a detailed examination of optimal depletion rates, given the oligopolistic nature of the coal industry. This discussion in Section 2, separated from the rest of this report, relies heavily upon economic theory which, because of its complexity, has becn subjected to little empirical analysis. It is not the intent of this report to provoke controversy on the theoretical issues involved in the problem of divestiture. There are several methods of analyzing the problem and, in Section 2 of this report we suggest ones which we believe make intuitive sense and are at 
least reasconable approximations of reality. These methods are believed to be consistent with established economic theory. However, whether one accepts the arguments made in Section 2 or not, the model results presented in the rest of Section 1 of this report effectively establish ranges and bounds on the impacts of horizontal divestiture. We now turn our attention to the estimation of the effects of horizontal divestiture on coal consumption. 
CHAPTER $1-4$

\section{SCENARIO DEVELOPMENT AND}

IMPACT ESTIMATION

The previous chapters of this report have described the problem, methodology developed, and underlying economic theory. This chapter presents the process used to represent divestiture in a scenario-oriented framework relating to legislative proposals. As mentioned in Chapter 1-1, there are four basic divestlture pollcy concepts which require analysis. These four areas are: divestiture - total; divestiture - major; restraint - total; and, restraint - major.

Several difficulties were encountered in attempting to implement all of the above alternative legislative concepts in the modeling environmont. These difficulties are discussed here for the benefit of DOE analysts who may do future work in characterizing scenarios within this modeling framework.

First, the original project specifications called for the analysis of divestiture in the period 1980 to 1985 . Once the project was begun, this was determined to be impossible. This franework would have required runs of the National Coal Model and the PIES model for two different time periods, 1980 and 1985. After the project had begun, we discovered that the 1980 version of both models had been retired by DOE. Much time and effort was spent in seeking a solution to this problcm. There are some methods for arriving at a 1980 interim set of figures and runs. These methods, however, were costed out and it was 
decided that they were simply impractical for the resources available.

Therefore, in the present report, we. study the restraint scenario on the assumption that the appropriate legislation has, in fact, been effective since 1975. We then calculate the effects hypothesized for the year 1985. This alteration is not considered to be a serious problem since we are assessing relative impacts. Therefore, while absolute realism is sacrificed, the direction and relative impacts of the results are still sound in our judgment.

The second area of consideration was the modeling of acquisition behavior in the forecast period. The question was one of how to integrate the concept of further acquisition of non-oil coal assets by oil companies. It is important to mention that we are not discussing the production owned by oil companies increasing due to planned new mine openings. The model handles that part. The problem relates to production which is due to come on board, which is currently non-oil, being acquired by oil companies.

We believe that, within the relevant time frame, the relative shares of oil and non-oil coal assets as defined in the model will change very little in the 75-85 period. The reasons for this are many. First, the simulation of acquisition in great detail is quite possible within the model; in fact, this is part of the problem. In order to simulate the acquisition, one needs to make detailed assumptions about the state in which 
the acquisition will occur, the type of coal, and the mine type. Percentage changes, on a unilateral basis, would not be much appropriate since the East and the liest will have different distributions of any potential oil acquisition behavior. Therefore, for all of these reasons, the process of simulating this acquisition behavior may introduce more bias than the gain from realism. This is especially true since we believe that the amount involved is negligible.

A simple straight-lining of the past acquisition behavior would also be inappropriate. This is because there was a large acquisition wave before the early 1970's. In past years there has been virtually no acquisition behavior. To project a trend over the past 5 to 10 years or, to consider just the last few years, would give entirely misleading results with respect to acquisition behavior. There has been a structural shift ill lle acquisition behavior of oil firms which is difficult to model without introducing more bias into the results.

There are severa1 reasons why there appcarg to be a recent 1011 in acquisition behavior and why we expect there to be only negligible acquisition behavior in the near future. First, most uf the medium- and large-sized coal companies have already been acquired by someone. Since each acquisition requires high transaction costs and increased visibility for the oil companics, there would appear to be 1ittle incentive to acquire large numbers of small coal companies. The oil companies in the past. havc appeared to show a preference for larger coal operations. A11 of the coal companies which would be left for acquisition 
are much smaller than the ones which were acquired in the past by oil companies. Almost all of the firms left represent less than one percent of the reserve base.

Perhaps the most significant disincentive for oil companies to acquire more coal companies, is the general uncertainty surrounding government intervention in the market. This takes the most direct form in terms of several different legislative proposals forcing horizontal divestiture or prohibition of future acquisitions. It comes in an indirect form through the myriad of proposed rules and regulations which affect the oil companies and coal companies.

The antitrust agencies such as FTC and Justice are particularly vigilant with regard to any interfuel competitive arrangement and are bound to scrutinize it in detail. Any large-scale acquisition of coal assets by oil companies would be extremely difficult to get approved by the antitrust community.

Finally, the method of using the relative shares in the model, suggests that the ultimate impact on a relative basis would be small. Therefore, even if some small amount of acquisition behavior occurred, it would have negligible impact on the results as we are using them. For all of the above reasons, it was jointly agreed by the Technical Project officer and Synergy, that it would be of 1 imited value to try and simulate any forecasted acquisition bchavior. However, the methodology for developing another set of data bases, reflecting a different relative distribution of oil vs non-oil coal assets in 1985, is straightforward 
and can be accomplished at a later date if it is decided that this is appropriate. One reason why one might want to build a high acquisition data base is that a range of sensitivity to the acquisition behavior would be established. Based on our limited resources and the expectation that the sensitivity would be negligible, the costs would outweigh the perceived benefits of such an activity.

Une of the more sophisticated probloms dealt with was tho depletion problem. The National Coal Model and the PTES model treat the rate of return almost purely as a cost factor which is negatively associated with the supply curve. This is appropriate and makes intuitive sense; however, one step beyond that is the problem and its impact upon the 1985 output. In Section 2 , a depletion model is set out which demonstrates that a decrease in the rate of discount may reduce 1985 output while. increasing the output of later years. An ideal model, based on a hierarchy of discounter present values for diffcrent mines and discount rates, would accommodate both effects. Therefore, while somewhat outside the scope of this study, we felt it necessary to evaluate the extent to which the depletion problem causcd a hias.

A separate model was developed and simulated to determine the impact of depletion effect. for the reasons given earlier, we have calculated that for the present report, the depletion effect can be regarded as secondary. Therefore, the direct effects of manipulating the rate of return in the coal model in its present form appears to be roughly correct. Also, it is not apparent as 
to which way the national interest 1 ies with regard to coal production "now" or "later."

In the future, it may be desirable to develop the use of PIES and the National Coal Model so that they can properly address the optimal depletion problems. The question of socially optimal depletion rates is an important one with regard to national energy policy. If, as is frequently alleged, oil companies are inclined to deplete more slowly than other companies, this is a hypothesis which could be tested using the techniques developed here in the PIES model.

The fourth difficulty encountered was in modeling the major versus non-major oil firm question. Again, this is one of those situations where it is quite possible to divide the majors and non-majors and simulate the impact in the model. However, there is a question of how to define a major. This is not a trïial problem since several studies have defined a major oil company in many different ways. The 1 ist of oil companies which is developed can then be used to separate production, committed reserves, and demonstrated reserves on an oil-owned, non-oilowned basis.

Analyses can be done, as shown in the next chapter, without actually creating another set of data bases. Creating another set of data bases is what is required to break out the majors trom the non-majuis. Again, while this is pnasible, it is costly and is not clear what information to use as a basis for doing this. Therefore, on a limited research budget, it is 
questionable whether the additional effort on this particular subject is warranted. We feel that adequate analysis can be made based on deductions from the data we have collected and - other analyses done. These deductions can then be related back to the runs involving all oil firms to arrive at conclusions.

The Perturbations of the Variables

The first section of this chapter described the basic scenarios, or legislative proposals, to be evaluated using the model and other analytical tools. For those proposals to be evaluated within the model, the changes of the variables relating to the scenarios must be hypothesized. These changcs, which are integrated in each model run, are based on the economic theory and empirical studies and models which we have developed in this study.

Because of the structure of the coal model and tho nature of the problem, we have narrowed down our choice of variables to perturb. We have focused on three economic variables. The first and, we believe, the most important is the rate of return. The others are the wage rate and capital requirements. We are also interested in productivity changes although this can be indirectly analyzed through the change in wage rate. The model has the capability to analyze changes in these varinhles eitliur up or down, for oil or non-oil, and for deep or surface. There are also other variables available for change. The number of permutations and combinations of variable changes which are available is large. With very little imagination, one can specify 30 to 40 different scenarios. 
Because of the capability of the system to analyze many different scenarios, it was necessary to limit the number of runs. These scenarios and variable changes were jointly determined by the DOE Technical Project Officer and Synergy. Before specifying the variable changes, a comment on the baseline scenario is necessary.

The baseline scenario is defined explicitly as that scenario which would result if there were no government intervention in the market and if conditions continued as in the past. It is also based on the PIES mid-level, TRENDLONG assumptions. Within our analytical framework and the structure of the models, this implies that any differential characteristics between oilowned coal assets and non-oil-owned coal assets would continue to exist in the absence of legislation.

On the other hand, a total divestiture legislation would imply that, conceptually. at least, all coal assets were now the same. Therefore, there would be no differential characteristics ascribed to oil-owned versus non-oil-owned since all would be non-oil-owned. In terms of the runs, this implies that the baseline would have differential variables while the total divestiture would have the same variables.

\section{Verification Run of the Mode1}

This study involved: the use of existing models in an experimental fashion; a large amount of data collection and verification; new program development; and, the development and application of 
several decision rules. There was some risk that the end result, a PIES run based upon this methodology, would be unusable. Further, the hypothesis that we could use the PIES run, could not be tested until very late in the study, thereby increasing the risk involved.

In order to test whether significant aberrations had been created by our methodology, several verification checks were creatcd before the run was done. The basic verifiration prucess involved running, the complete set of models from the input coal data bases through to the PIES Wonder Cookie report. This run was to be made using the after-ownership versions of the models and data bases but with no variable changes. This run was then to be compared to a run done before ownership using the same PIES assumptions. Therefore, once a run had been made all the way through, we had two sets of luns, une representing the situation before ownership breakout and one representing the situation after ownership breakout. These two runs ideally would have been exactly the same. In fact, because of the new methodology introduced, we knew there wolld be small differences between the two results.

In conjunction with personnel from the Office of Coal Analysis at DOE, we developed a set of checks to be made when comparing the two runs.. These chccks were designed to insure that there were no major problems which needed to be corrected before the models could he used. Five individual codl type/region sets of 
figures were reviewed and compared for the two sets of runs. Our decision rule to determine if we had serious difficulty was to look at the percentage difference between prices and quantities for those five cells of the coal type/region matrix. These five cells represented ten percent of the available 50 cells in that matrix. They were chosen because they were deemed to be the cells which would show any problems which had developed. The feeling of the personnel in the Office of Coal Analysis was that if these five cells were within our tolerance range, there would be a relatively high level of confidence which could be placed in the rest of the results. Tables I-4 through I-6 show the results of this comparison and verification test.

Table I-4 presents, for each of the five cells, the 1985 forecast of production before and after ownership and the percentage change. The results were reassuring in that they al1 fell within the 20 percent decision rule (although CW/C4 is very close) and they show differential directions. The fact that some went up and some went down has the overall effect of balancing out any problems. Therefore, while individual cells showed a fair range of difference, the sum of the pairs was moderated to a relatively small negative 6 percent difference.

Table I-5 shows that, in the aggregate, the results are even more favorable. The East shows a very small increase in production while the West shows a 7 percent decrease. Overa11, for the U.S. as a whole however, the total difference is on $1 y$ 2 percent. 
TABLE I -4

COMPARISON OF PRODUCTION FOR SELECTED COAL TYPE/

REGION PAIRS BETWEEN PIES RUNS

BEFORE AND AFTER OWNERSHIP DISAGGREGATION

\begin{tabular}{|c|c|c|c|c|c|c|}
\hline & & & & $\begin{array}{l}1985 \mathrm{P} \\
\text { (MM Sh. }\end{array}$ & $\begin{array}{l}\text { oduction } \\
\text { ons/Year) }\end{array}$ & $\begin{array}{c}\text { Percentage } \\
\text { Change }\end{array}$ \\
\hline Coal Types & Code & Regions & Code & $\begin{array}{c}\text { Before } \\
\text { Ownership }\end{array}$ & $\begin{array}{c}\text { After } \\
\text { Ownership }\end{array}$ & $\frac{\overline{A O-B O}}{\mathrm{BO}}$ \\
\hline $\begin{array}{l}\text { High sulfur } \\
\text { Bituminous }\end{array}$ & $\mathrm{CH}$ & $\begin{array}{l}\text { Northern } \\
\text { Appalachia }\end{array}$ & $C-1$ & 74.82 & 84.46 & $+12.9 \%$ \\
\hline Premium & CM & $\begin{array}{l}\text { Central } \\
\text { Appalachia }\end{array}$ & $C-2$ & 156.64 & 138.51 & -11.6 \\
\hline $\begin{array}{l}\text { High Sulfur } \\
\text { Mid- } \\
\text { Bituminous }\end{array}$ & $\mathrm{CW}$ & Midwest & C -4 & 165.14 & 132.34 & -19.9 \\
\hline $\begin{array}{l}\text { Low-Sulfur } \\
\text { Sub } \\
\text { Bituminous }\end{array}$ & $\mathrm{CX}$ & $\begin{array}{l}\text { N.W. Great } \\
\text { Plains }\end{array}$ & $C-8$ & 124.14 & 131.26 & +5.7 \\
\hline $\begin{array}{l}\text { Medium } \\
\text { Sulfur } \\
\text { Lignite }\end{array}$ & $\mathrm{CU}$ & Gulf & $C-6$ & 51.90 & 51.90 & $-0-$ \\
\hline $\begin{array}{l}\text { SUM OF } \\
\text { PAIRS }\end{array}$ & & & & 572.64 & 538.47 & -6.0 \\
\hline
\end{tabular}

Source: PIES Wonder Cookie Reports 
TABLE I -5

COMPARISON OF OVERALL COAL PRODUCTION

FOR PIES RUNS BEFORE AND AFTER OWNERSHIP DISAGGREGATION

\begin{tabular}{|l|c|c|c|}
\hline & 1985 PRODUCTION & (MM SH. TONS/YEAR) \\
\hline & BEFORE OINERSHIP & AFTER OWNERSHIP & PERCENTAGE CHANGE \\
\hline \multirow{2}{*}{ EAST } & 678.5 & 684.4 & $+1 \%$ \\
WEST & 355.4 & 329.5 & $-7 \%$ \\
U.S. & 1034.0 & & $-2 \%$ \\
TOTAL & & $1,014.0$ & \\
& & & \\
\hline
\end{tabular}

Source: PIES Wonder Cookie Reports 
We also looked at several different coal prices to compare tine two runs on the price side. The results of this exercise are shown in Table I-6. Overal1, coal prices appear to change on the order of 11-i2 percent. Again, this is well within the 20 percent tolerance limit which had been set. In the case of prices, however, the direction was always upward. This result is consistent with the overall decline in production which would imply higher prices.

On the basis of these verification checks and results, we decided that the basic methodology was working correctly and that the two runs were close enough to indicate that confidence. could be placed in the results.

All of the scenarios discussed hereafter are based upon the after-ownership disaggregation data base and PIES runs. The . after-ownership version is used to establish the baseline and is used for all alternative scenarios. It is important to remember that it is consistent and correct to apply this approach on a relative basis to the new set of models. However, direct comparisons between runs here and PIES runs done for any other purpose within DOE cannot be made directly. There must be an adjustment made for the difference in the two versions of the coal model employed. The method of doing this would be to simply adjust the results by the amount of the difference between the original PIES run and the new PIES run from any results presented here. 
TABLE I -6

COMPARISON OF COAL PRICES

BEFORE AND AFTER OWNERSHIP DISAGGREGATION

\begin{tabular}{|c|c|c|c|c|c|c|c|}
\hline \multirow[t]{2}{*}{ SECTOR } & FUEL & \multicolumn{2}{|c|}{$\begin{array}{l}1985 \\
\text { PRICE } \\
\text { BO }\end{array}$} & \multicolumn{2}{|c|}{$\begin{array}{l}1985 \\
\text { PRICE } \\
\quad \text { AO }\end{array}$} & \multicolumn{2}{|c|}{$\frac{\text { PERCENTAGE CHANGE }}{\left(\frac{\mathrm{AO}-\mathrm{BO})}{\mathrm{BO}}\right)}$} \\
\hline & & PHYS. & BTU & PHYS. & BTU & PHYS. & BTU \\
\hline COMMERCIAL & COAL & $\$ 34.74$ & $\$ 1.54$ & $\$ 38.89$ & $\$ 1.73$ & $+11.9 \%$ & $+12.3 \%$ \\
\hline INDUSTRIAL & COAL & 33.53 & 1.49 & 37.86 & 1.68 & $+12.9 \%$ & $+12.8 \%$ \\
\hline INDUSTRIAL & $\begin{array}{l}\text { MET } \\
\text { COAL }\end{array}$ & 46.56 & 1.72 & 51.54 & 1.91 & $+10.6 \%$ & $+11.0 \%$ \\
\hline
\end{tabular}

SOURCE: PIES Wonder Cookie Reports 
CHAPTER $1-5$

RESULTS

This chapter describes and interprets the results which stem from the analytical. framework developed in previous chapters. In most cases, the PIES runs are summarized and tables have been extracted which are relevant to the conclusions. However, for those interested in the total PIES runs, a full set of bound computer printouts relating to each run of each model and submodel was delivered to the Technical Project officer. Thcsc bound printouts include, in addition to the PIES output tables, original input data sets, supply curves for 192 NCM region coal type pairs merged for oil and non-oil, and supply curves for 50 PIES region/coal type pairs.

Four basic types of scenarios are considered in this chapter. There are two types of baseline cases, reflecting divergent theoretical and behavioral assumptions. There is a Total Divesliture scenario and a Restraint scenario. Further, ranges have been established for the variable perturbations and incorporated into runs. The two baselines and the Total Divestiture results are reported at this time. The PIES runs for the Restraint scenario and range estimates will be run by DOE in the near fut.ure. When those are completed, a short addendum to this report will be produced describing those results.

\section{Results for the Adjusted PIES Baseline Rurs}

The previous chapter described the methodology and rationale behind the adjusted baselines. The adjusted baselines are 
representative of the forecasted 1985 situation which would occur if past relationships continue. It is assumed that no government intervention in the form of horizontal divestiture legislation will be brought about. Therefore, these runs represent the baseline forecasts against which other alternative scenarios are evaluated.

As mentioned in earlier chapters, there are two baselines because of an unresolved conflict regarding the nature of the relationship between ownership and rate of return as defined. in the model. Baseline 1 is one which assumes some conbination of characteristics of synergism and growth maximization behavior on the part of oil firms with coal assets. The implication of this is that, in the model, oil firms' rate of return on coal assets will be lower than non-oil-owned coal assets. The results for Baseline 1 are shown for $0 i 1$, $R O R=3 \%$, and non-oil, ROR $-8 \%$. The $8 \%$ figure is considered to be a normal rate of return in the coal market.

The second bascline case, Baseline 2 assumes that oil companies are monopolists, and therefore they will pursue a policy which leads to higher prices and lower quantities. This is manifested in the model by a higher rate of return for oil-owned assets relative to non-oil-owned assets. The results shown for Baseline 2 are for oil, $R O R=13 \%$ and non-oil, $R O R=8 \%$. The first results below are from the Baseline 1 scenario.

The relevant summary reports from the PIES Wonder Cookie report have been extracted and are presented here. Tahles I-7 and I-8 are the PIES Executive Data Summary lables in physical 
units and trillions of BTU's, respectively. Table $I-7$ is the PIES Coal Regional Production Summary (by mine type). Tables I-10 and I-1I are the PIES Demand Regional Retail Price Summaries in dollars per units and millions of BTU; respectively.

Table. I-7 shows that for Baseline 1, a total 1985 supply of coal of approximately $1,029.7$ million short tons is forecast. Referring to Table I-8, this domestic supply figure is roughly equivalent to 22.7 quadrillion BTU's. The total supply of energy in 1985, according to PIES, is estimated to be approximately 94.3 quadrillion BTU's.

'lable I-9 contains the coal regional production summary by mine type. In describing these alternative scenarios later, we will be concerned primarily with total East, total West, and the total U.S. figures. Therefore, while the individual mine type and region figures are of interest, we are primarily focusing our analysis on the overall totals. From Table I-9, the 1985 forecast value for total Eastern production is 685.9 million short tons per year. For the West, this figure is 343.8 million short tons per year. This gives a total U.S. production figure in 1985 of $1,029.7 \mathrm{mil1i}$ on short tons of annual mine production. This figure represents a substantial increase over 1975 production of 639.9 million short tons.

Table I-10 shows that the residential and commercial prices for coal in 1985 are expected to be $\$ 37.53$ per ton - with an industrial price of $\$ 36.49 .^{1 /}$ Commercial and industrial prices

1/ In the middle of making runs during this project, DOE changed their prices to reflect 1978 in the newest PIES runs. However, our initial runs were done with 1975 dollars. Therefore, we have kept prices in 175 terms with a deflator factor from DOE, $\$ 44.22 / 1.17819=\$ 37.53$. Also, the new oil import price of $\$ 15.52$ is equivalent to al1 old runs showing a $\$ 13.00$.import price. 
TABLE I-7

PAGE 9BS MID-RBSEE/THENDLONG SCENAKIO WITH NATURAL GAS REGULATION

\section{OIL IAPOFY PRICE: 15.32}

RUN DATEI

EXECUTIVE DATA SUAMAKY

UITED STATES TOTAL GKOSS SUPPLY/CONSUMPTION OF ENERGY RESOURCES ENEKGY SOURCES III STANDARD PHYSICAL UNITS PEH YEAR

\begin{tabular}{|c|c|c|c|c|c|c|c|}
\hline SECTUR & $\begin{array}{c}\text { COAL } \\
\text { (MHST) }\end{array}$ & $\begin{array}{c}\text { OIL } \\
\text { (MHB) }\end{array}$ & $\begin{array}{c}\text { GAS } \\
\text { (BCF) }\end{array}$ & $\begin{array}{l}\text { NUCLEAR } \\
\text { (MMAKWM) }\end{array}$ & $\begin{array}{l}\text { HYYHEO,SOLAR, } \\
\text { GEOTHERMAL } \\
\text { (MMKKKH) }\end{array}$ & $\begin{array}{l}\text { SOLAR/GEO } \\
\text { FOSSIL SUBST } \\
\text { (TBTU) }\end{array}$ & $\begin{array}{c}\text { TOISLELEC, } \\
\text { - OISIRIBUTED } \\
\text { (KMAKNH) }\end{array}$ \\
\hline $\begin{array}{l}\text { DOMESIIE SUPPLY } \\
\text { (COAL,GLS, ELEC,) } \\
\text { (CRIDE) } \\
\text { (CO-PROOUCTS/ASSOC. GAS) } \\
\text { (SYNTHETICS) } \\
\text { (SHALE) } \\
\text { (OIRECT SOLAR/GEO) }\end{array}$ & $\begin{array}{c}1029.72 \\
1029.12\end{array}$ & $\begin{array}{r}3735.43 \\
3262.15 \\
056.13 \\
17.15\end{array}$ & $\begin{array}{r}16726.60 \\
13505.32 \\
3221.32\end{array}$ & $\begin{array}{l}566.49 \\
566.49\end{array}$ & $\begin{array}{l}410.02 \\
395.68\end{array}$ & 119.86 & $\begin{array}{l}3029.60 \\
3029.60\end{array}$ \\
\hline $\begin{array}{l}\text { IMPORTSI } \\
\text { (CRUDE) } \\
\text { (PRODUCTS) } \\
\text { (LNG) } \\
\text { (EANADIAHAMEXICAN) } \\
\text { (EOAL). }\end{array}$ & 70.000 & $\begin{array}{r}0022.27 \\
2832.76 \\
1169.51\end{array}$ & $\begin{array}{r}8852.60 \\
.906 .60 \\
906.00\end{array}$ & & $\cdots$ & & \\
\hline TOTAL SUPPLY & 955.72 & 7757.69 & 28579,25 & 566.49 & 010.02 & 119.86 & 3029.60 \\
\hline GAINS $(+) / \operatorname{LOSSES}(-)$ & . & 204.57 & & $46.38=$ & $35.70-$ & & 253.060. \\
\hline $\begin{array}{l}\text { CONSUMPTIONS } \\
\text { RESIDENTIAL } \\
\text { COMMERCIAL } \\
\text { INOUSTKIAL } \\
\text { TRANSPURTATION } \\
\text { ELECTRICAL GENERATION } \\
\text { SYNTHETICS }\end{array}$ & $\begin{array}{r}1.03 \\
19.55 \\
196.81 \\
10.02 \\
13.64 \\
13.66\end{array}$ & $\begin{array}{r}709.19 \\
595.75 \\
2035.28 \\
3900.80 \\
550.51 \\
169.11\end{array}$ & $\begin{array}{l}5261.75 \\
1845.58 \\
4856.66 \\
398.26 \\
2062.11 \\
872.16=\end{array}$ & & $\begin{array}{l}0.46 \\
5.09 \\
0.80\end{array}$ & $\begin{array}{l}93.39 \\
20.49 \\
56.06\end{array}$ & $\begin{array}{r}836.73 \\
692.09 \\
1221.75 \\
9.05 \\
2750.56\end{array}$ \\
\hline - TOTAL DOMESTIC CONSUMPTIDN & 956.72 & 7962.60 & 18552.20 & . & 14.35 & 119.86 & .00 \\
\hline
\end{tabular}

NOTE: OIL IMPOATS IN MMB/CD 11.02

GAS CUNSJMPTION IN THE IRANSPORTATION SECTOR INCLUDES NATURAL GAS TRANSPDRTATION LOSSES.

JNOUSTRIAL CONSIJMPYION INCLUDES REFINERY FUEL CONSUMPTION.

SUPPLYIOERAND IMHALANCES MAY BE DUE TO ERROHS WITKIN YME EOUILIBRATION CONYERGENCE TOLERANCE, 


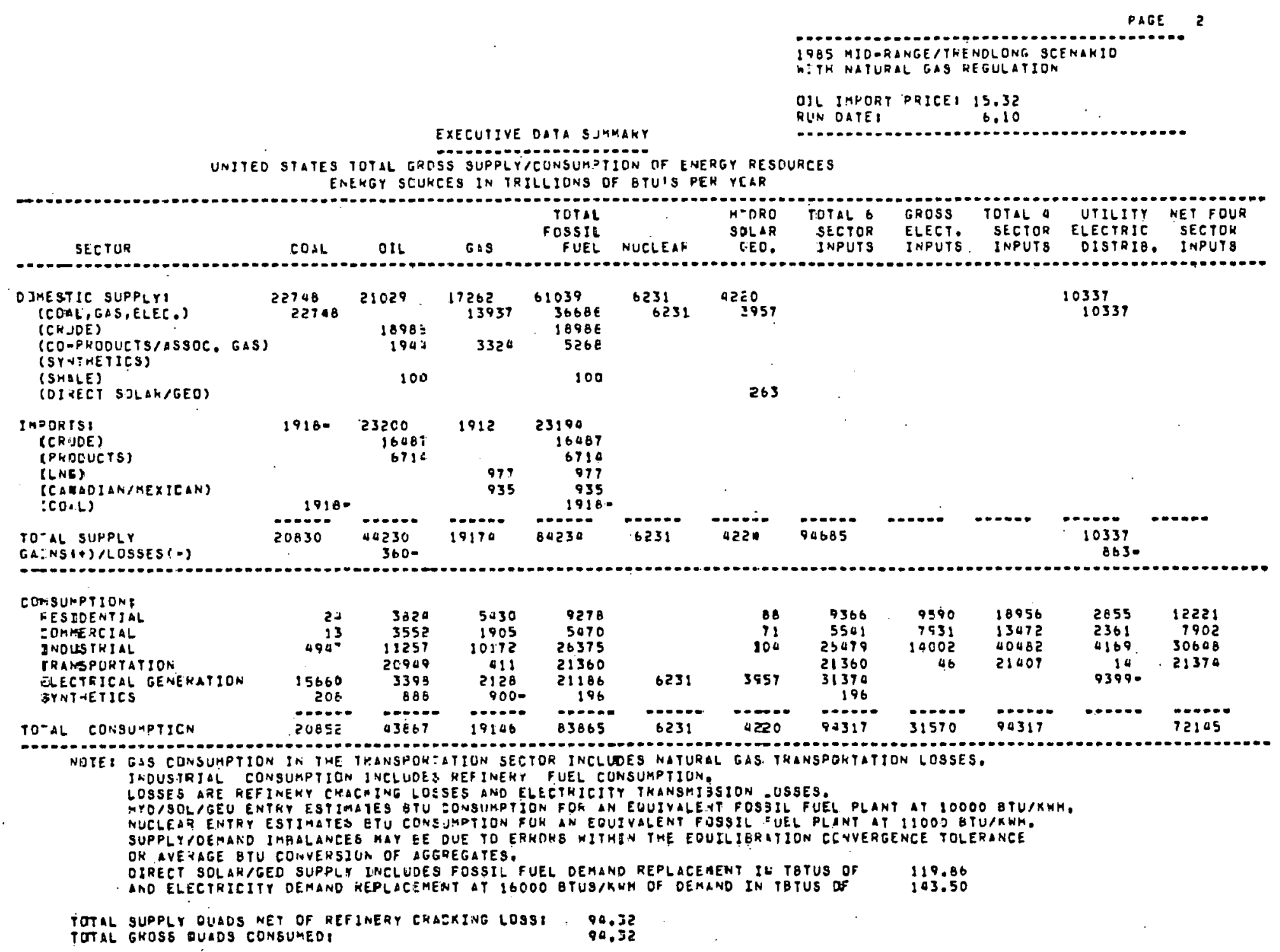


$19 B 5$ MIOPRANGE/TRENDLONA SCENARIO
ITH NATURAL GAS REGULATION

OIL IMPORT PRIEEI 15.32

RUN OATEI

6.10

COAL KEGIUNAL PRODUETION SUMAARY IN MILLION SHORT TONS PER YEAR (BY MINE TYPE)

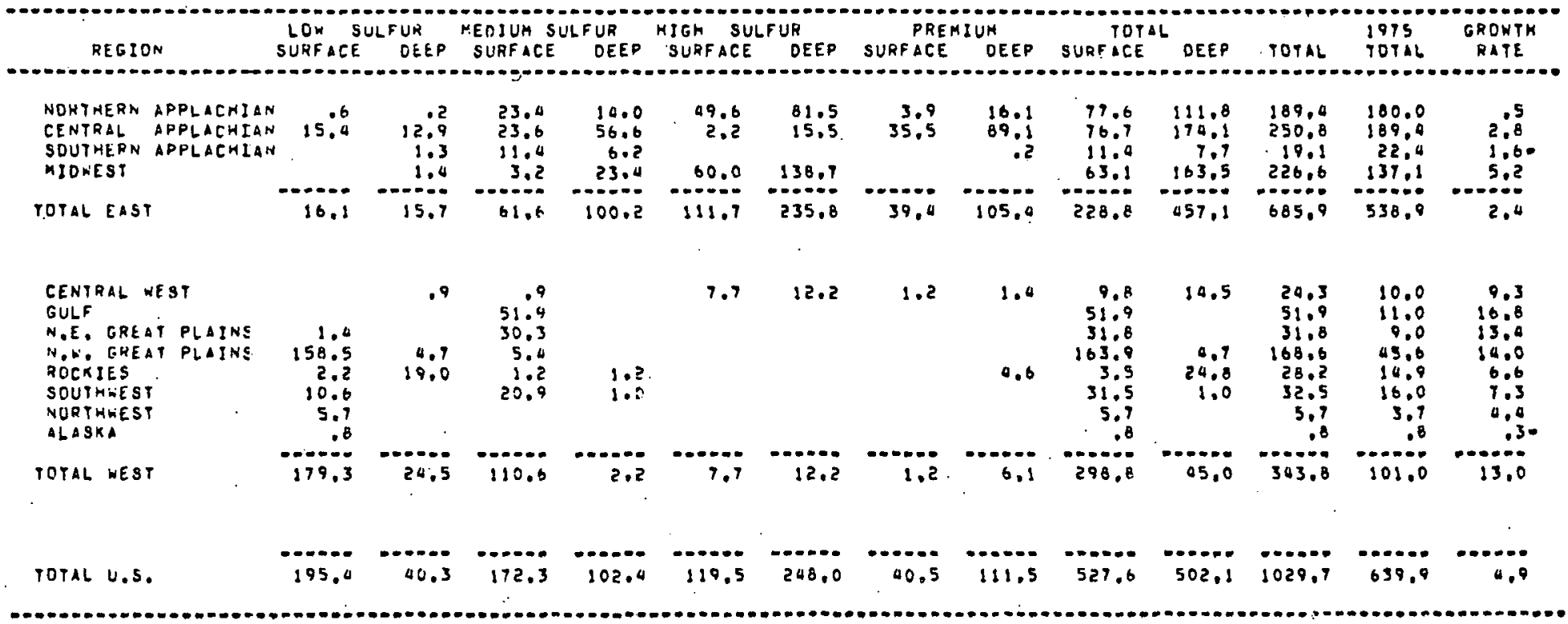


TABLE $I-1 \theta$

PAGE 2!

1985 MIDFALNGE/TRENOLONG SCENARIO
WITH NATURAL GAS REGULATION

\begin{tabular}{l} 
OIL IMPORT PRICES 15,32 \\
RUN OATE: \\
\hline O.10
\end{tabular}

DEMANO REGION RETAIL PRICE SUMMAKY IN 997 B SI STANDARD PHYSICAL UNIT

\begin{tabular}{|c|c|c|c|c|c|c|c|c|c|c|c|}
\hline SECTOR(FIJLL) & NWIENG, & NY/NJ & MID-ATL & $S,-A T L$ & HIOWESI & S. -WEST & CENTRAL & N-CNTKL & WEST & N. WEST & TOIAL \\
\hline $\begin{array}{l}\text { RESIOENTIAL } \\
\text { (ELECT, } \\
\text { IDIST, } \\
\text { ILG! } \\
\text { ICOAL) } \\
\text { ING: }\end{array}$ & $\begin{array}{l}45.79 \\
22.69 \\
15.62 \\
48.82 \\
9.67\end{array}$ & $\begin{array}{l}50.36 \\
23.17 \\
16.08 \\
06.13 \\
4.26\end{array}$ & $\begin{array}{r}07.96 \\
24.26 \\
17.33 \\
40.01 \\
3.69\end{array}$ & $\begin{array}{l}38.23 \\
20.68 \\
17.33 \\
46.60 \\
3.25\end{array}$ & $\begin{array}{r}41.06 \\
22.50 \\
15.99 \\
43.73 \\
3.26\end{array}$ & $\begin{array}{r}40.81 \\
23.99 \\
15.73 \\
39.21 \\
3.98\end{array}$ & $\begin{array}{r}13.91 \\
21.54 \\
35.69 \\
91.41 \\
2.16\end{array}$ & $\begin{array}{r}33.20 \\
22.61 \\
16.32 \\
34.76 \\
2.33\end{array}$ & $\begin{array}{r}43.40 \\
22.40 \\
15.80 \\
42.57 \\
3.46\end{array}$ & $\begin{array}{r}19.93 \\
22.40 \\
15.80 \\
39.76 \\
3.76\end{array}$ & $\begin{array}{r}40.91 \\
22.92 \\
16.21 \\
09.22 \\
3.18\end{array}$ \\
\hline 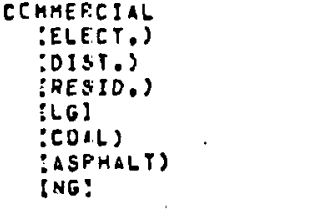 & $\begin{array}{l}45.42 \\
21.27 \\
19.19 \\
13.10 \\
48.82 \\
19.19 \\
3.98\end{array}$ & $\begin{array}{l}60.07 \\
21.68 \\
18.80 \\
13.10 \\
46.13 \\
19.19 \\
3.64\end{array}$ & $\begin{array}{l}95.99 \\
21.95 \\
20.73 \\
13.10 \\
49.01 \\
19.19 \\
3.20\end{array}$ & $\begin{array}{l}38.68 \\
21,97 \\
18,41 \\
13,10 \\
46,60 \\
19,58 \\
2,12\end{array}$ & $\begin{array}{l}41.57 \\
21.04 \\
19.64 \\
13.98 \\
43.93 \\
19.27 \\
2.86\end{array}$ & $\begin{array}{l}39.13 \\
21.28 \\
19.50 \\
13.10 \\
39.21 \\
19.83 \\
9.59\end{array}$ & $\begin{array}{l}43.00 \\
20.50 \\
19.56 \\
13.88 \\
61.01 \\
18.92 \\
3.59\end{array}$ & $\begin{array}{l}30.33 \\
21.25 \\
19: 04 \\
13.93 \\
34.76 \\
19.21 \\
3.23\end{array}$ & $\begin{array}{r}40.16 \\
20.76 \\
18.35 \\
13.10 \\
42.57 \\
18.92 \\
2.92\end{array}$ & $\begin{array}{l}19.85 \\
20.76 \\
17.90 \\
13.10 \\
39.76 \\
18.02 \\
3.15\end{array}$ & $\begin{array}{l}91.00 \\
21.35 \\
18.95 \\
13.50 \\
29.22 \\
19.00 \\
3.04\end{array}$ \\
\hline $\begin{array}{l}\text { RAN MATERIAL: } \\
: \text { GI } \\
\vdots O I L) \\
\text { :NGI }\end{array}$ & $\begin{array}{r}13.89 \\
19.19 \\
3.37\end{array}$ & $\begin{array}{r}18.87 \\
19.19 \\
2.92\end{array}$ & $\begin{array}{r}: 8.68 \\
: 9.19 \\
2.77\end{array}$ & $\begin{array}{r}18,73 \\
19,08 \\
2,26\end{array}$ & $\begin{array}{r}18.81 \\
19.27 \\
2.52\end{array}$ & $\begin{array}{r}13.69 \\
13.23 \\
3.28\end{array}$ & $\begin{array}{r}18.07 \\
18.92 \\
3.23\end{array}$ & $\begin{array}{r}18.58 \\
19.21 \\
2.73\end{array}$ & $\begin{array}{r}18.07 \\
18.42 \\
2.52\end{array}$ & $\begin{array}{r}18.07 \\
18.02 \\
2.04\end{array}$ & $\begin{array}{r}18.53 \\
18.98 \\
2.03\end{array}$ \\
\hline 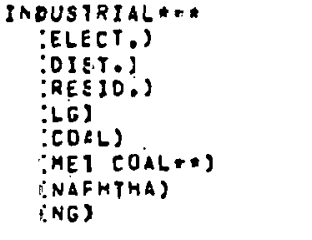 & $\begin{array}{l}37.14 \\
21.25 \\
10.55 \\
14.67 \\
46.82 \\
90.73 \\
10.89 \\
3.39\end{array}$ & $\begin{array}{l}32.39 \\
21.57 \\
19.49 \\
15.09 \\
16.13 \\
73.94 \\
18.87 \\
2.92\end{array}$ & $\begin{array}{l}38.00 \\
22.52 \\
20.22 \\
15.62 \\
04.01 \\
91.21 \\
18.86 \\
2.79\end{array}$ & $\begin{array}{l}32.61 \\
22.46 \\
18.19 \\
15.39 \\
06.60 \\
90.59 \\
18.73 \\
2.31\end{array}$ & $\begin{array}{l}32.65 \\
21.02 \\
19.69 \\
15.31 \\
43.75 \\
92.37 \\
18.81 \\
2.52\end{array}$ & $\begin{array}{l}32.95 \\
21.17 \\
1.9 .78 \\
21.05 \\
31.21 \\
95.13 \\
19.49 \\
3.28\end{array}$ & $\begin{array}{l}36.59 \\
30.05 \\
19.37 \\
15.07 \\
61.41 \\
50.61 \\
18.47 \\
3.23\end{array}$ & $\begin{array}{l}25.23 \\
25.97 \\
18.90 \\
15.36 \\
39.76 \\
97.51 \\
18.58 \\
2.73\end{array}$ & $\begin{array}{r}39.19 \\
20.76 \\
18.33 \\
10.81 \\
92.57 \\
107.68 \\
18.07 \\
2.52\end{array}$ & $\begin{array}{r}13.18 \\
20.76 \\
18.68 \\
14.81 \\
39.96 \\
210.90 \\
18.07 \\
2.09\end{array}$ & $\begin{array}{l}32.16 \\
21.40 \\
18.93 \\
15.21 \\
42.98 \\
92.77 \\
88.62 \\
2.02\end{array}$ \\
\hline $\begin{array}{l}\text { TRLNSFORTAYION. } \\
\text { IELECT,J } \\
\text { IOIST.S } \\
\text { IRESIO.S } \\
\text { ILES } \\
\text { IGASOLINES } \\
\text { IJET FUELS }\end{array}$ & $\begin{array}{l}42.76 \\
27.93 \\
18.55 \\
13.10 \\
3: .71 \\
22.98\end{array}$ & $\begin{array}{l}28.72 \\
28.25 \\
19.44 \\
13.10 \\
32.88 \\
23.57\end{array}$ & $\begin{array}{l}02.70 \\
29.20 \\
20.22 \\
13.10 \\
31.59 \\
25.05\end{array}$ & $\begin{array}{l}35.81 \\
.29 .14 \\
18.19 \\
13.10 \\
31.15 \\
25.29\end{array}$ & $\begin{array}{l}36.89 \\
27.80 \\
19.69 \\
13.59 \\
31.09 \\
22.59\end{array}$ & $\begin{array}{l}3.9 .60 \\
29.85 \\
13.78 \\
13.10 \\
3.93 \\
2.9 .20\end{array}$ & $\begin{array}{l}60.64 \\
27.13 \\
19.37 \\
13.08 \\
16.58 \\
21.91\end{array}$ & $\begin{array}{l}29.62 \\
28.16 \\
18.70 \\
13.93 \\
30.79 \\
23.22\end{array}$ & $\begin{array}{l}38.99 \\
27.44 \\
28.33 \\
13.10 \\
31.54 \\
22.80\end{array}$ & $\begin{array}{l}16.94 \\
27.04 \\
18.68 \\
13.10 \\
31.61 \\
22.84\end{array}$ & $\begin{array}{l}45.38 \\
28.11 \\
18.94 \\
13.29 \\
31.28 \\
23.51\end{array}$ \\
\hline
\end{tabular}


TABLE $I-11$

HAGE 22

J985 MIDTKONGE/TKEAOLONG SCENAKIO

WITH NATURAL GAS HEGULATION

OIL IMPOHT PAICE: 15.32
RUN OATE:
6.10

DEMANO REgION AVEKAGE RETAIL PRICE SUMMARY IN I978 S/MILLION BTUS

\begin{tabular}{|c|c|c|c|c|c|c|c|c|c|c|c|}
\hline SECTORIFUEL: & $N=-E N G$. & NYINJ & MID.ATL & $\begin{array}{c}\text { OEMA } \\
S . \triangle A T L\end{array}$ & $\begin{array}{l}\text { DREGIO } \\
\text { MIOWEST }\end{array}$ & 5. WEST & CENTRAL & N.CNTRL & NESY & N, - WEST & TOTAL \\
\hline $\begin{array}{l}\text { RESIOENTIAL } \\
\text { (ELECT,.) } \\
\text { (OIST.j } \\
\text { (LG) } \\
\text { (COAL) } \\
\text { (NG) }\end{array}$ & $\begin{array}{r}5.12 \\
13.91 \\
3.90 \\
3.90 \\
2.17 \\
4.53\end{array}$ & $\begin{array}{r}5.67 \\
15.93 \\
3.98 \\
0.01 \\
2.05 \\
4.13\end{array}$ & $\begin{array}{r}6.17 \\
19.06 \\
0.16 \\
0.32 \\
1.96 \\
3.57\end{array}$ & $\begin{array}{r}7.94 \\
11.21 \\
4.29 \\
9.32 \\
2.09 \\
3.15\end{array}$ & $\begin{array}{r}4.58 \\
12.21 \\
3.80 \\
3.99 \\
3.94 \\
3.10\end{array}$ & $\begin{array}{r}5.22 \\
11.96 \\
3.91 \\
3.92 \\
1.74 \\
2.40\end{array}$ & $\begin{array}{r}4.41 \\
12.89 \\
3.70 \\
3.91 \\
3.84 \\
2.09\end{array}$ & $\begin{array}{l}4.11 \\
9.79 \\
3.88 \\
4.07 \\
1.50 \\
2.26\end{array}$ & $\begin{array}{r}5.59 \\
12.72 \\
3.85 \\
3.94 \\
1.89 \\
3.35\end{array}$ & $\begin{array}{l}9.83 \\
5.80 \\
3.85 \\
3.80 \\
1.77 \\
3.65\end{array}$ & $\begin{array}{l}5.02 \\
11.84 \\
3.93 \\
4.00 \\
1.97 \\
3.00\end{array}$ \\
\hline $\begin{array}{l}\text { COMMEREIAL } \\
\text { (ELECT:S } \\
\text { (OISI:') } \\
\text { (RESID.) } \\
\text { (LE) } \\
\text { (CDAL) } \\
\text { (ASPMALT) } \\
\text { (NG) }\end{array}$ & $\begin{array}{r}4.80 \\
13.31 \\
3.65 \\
2.89 \\
3.27 \\
2.17 \\
3.20 \\
3.05\end{array}$ & $\begin{array}{r}6.48 \\
17.72 \\
3.72 \\
2.99 \\
3.27 \\
2.05 \\
3.20 \\
3.52\end{array}$ & $\begin{array}{r}6.50 \\
13.97 \\
3.77 \\
3.30 \\
3.27 \\
1.96 \\
3.20 \\
3.10\end{array}$ & $\begin{array}{r}6.71 \\
13.34 \\
3.77 \\
2.93 \\
3.27 \\
2.07 \\
3.18 \\
2.63\end{array}$ & $\begin{array}{r}5.18 \\
12.18 \\
3.61 \\
3.12 \\
3.49 \\
1.94 \\
3.21 \\
2.77\end{array}$ & $\begin{array}{r}6.07 \\
11.35 \\
3.65 \\
3.00 \\
3.27 \\
1.79 \\
3.19 \\
2.51\end{array}$ & $\begin{array}{r}6.10 \\
12.60 \\
3.52 \\
3.11 \\
3.46 \\
1.86 \\
3.15 \\
3.08\end{array}$ & $\begin{array}{l}5.29 \\
8.89 \\
3.65 \\
3.03 \\
3.47 \\
1.54 \\
3.20 \\
3.13\end{array}$ & $\begin{array}{r}6.87 \\
11.97 \\
3.56 \\
2.92 \\
3.29 \\
1.89 \\
3.09 \\
2.63\end{array}$ & $\begin{array}{l}4.22 \\
5.82 \\
3.56 \\
2.85 \\
3.27 \\
1.07 \\
3.07 \\
3.05\end{array}$ & $\begin{array}{r}5.88 \\
12.13 \\
3.67 \\
3.01 \\
3.38 \\
1.98 \\
3.17 \\
2.95\end{array}$ \\
\hline $\begin{array}{l}\text { RAW MATERIAL, } \\
\text { (LG) } \\
\text { (OIL) } \\
\text { (NG) }\end{array}$ & $\begin{array}{l}3.43 \\
3.60 \\
3.20 \\
3.28\end{array}$ & $\begin{array}{l}3.35 \\
3.60 \\
3.20 \\
2.83\end{array}$ & $\begin{array}{l}3.18 \\
3.59 \\
3.20 \\
2.68\end{array}$ & $\begin{array}{l}2.92 \\
.3 .57 \\
3.18 \\
2.19\end{array}$ & $\begin{array}{l}3.25 \\
3.59 \\
3.21 \\
2.40\end{array}$ & $\begin{array}{l}3.27 \\
3.52 \\
3.19 \\
2.21\end{array}$ & $\begin{array}{l}3.29 \\
3.52 \\
3.15 \\
3.13\end{array}$ & $\begin{array}{l}3.20 \\
3.96 \\
3.20 \\
2.65\end{array}$ & $\begin{array}{l}3.08 \\
3.40 \\
3.09 \\
2.44\end{array}$ & $\begin{array}{l}2.92 \\
3.94 \\
3.07 \\
2.37\end{array}$ & $\begin{array}{l}3.22 \\
3.53 \\
3.16 \\
2.36\end{array}$ \\
\hline 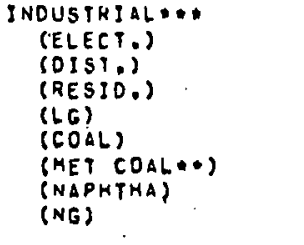 & $\begin{array}{r}4.89 \\
11.06 \\
3.65 \\
2.95 \\
3.66 \\
2.19 \\
3.58 \\
3.60 \\
3.28\end{array}$ & $\begin{array}{l}0.79 \\
0.49 \\
3.70 \\
3.09 \\
3.94 \\
2.05 \\
3.08 \\
3.60 \\
2.83\end{array}$ & $\begin{array}{r}0.51 \\
11.14 \\
3.87 \\
3.22 \\
3.95 \\
1.96 \\
3.38 \\
3.59 \\
2.68\end{array}$ & $\begin{array}{l}5.16 \\
9.56 \\
3.86 \\
2.89 \\
3.96 \\
2.07 \\
3.50 \\
3.57 \\
2.20\end{array}$ & $\begin{array}{l}9.26 \\
9.57 \\
3.61 \\
3.10 \\
3.82 \\
1.90 \\
3.42 \\
3.59 \\
2.09\end{array}$ & $\begin{array}{l}3.03 \\
9.66 \\
3.63 \\
2.99 \\
3.70 \\
1.70 \\
3.52 \\
3.52 \\
2.21\end{array}$ & $\begin{array}{r}9.90 \\
10.72 \\
3.51 \\
3.08 \\
3.76 \\
1.04 \\
3.36 \\
3.52 \\
3.13\end{array}$ & $\begin{array}{l}3.91 \\
7.39 \\
3.69 \\
2.97 \\
3.85 \\
1.50 \\
3.61 \\
3.56 \\
2.65\end{array}$ & $\begin{array}{r}3.92 \\
10.02 \\
3.56 \\
2.92 \\
3.69 \\
1.89 \\
3.99 \\
3.44 \\
2.44\end{array}$ & $\begin{array}{l}3.28 \\
3.86 \\
3.56 \\
2.97 \\
3.69 \\
1.79 \\
9.118 \\
3.04 \\
2.37\end{array}$ & $\begin{array}{l}4.02 \\
9.43 \\
3.07 \\
3.01 \\
3.79 \\
1.01 \\
3.09 \\
3.55 \\
2.34\end{array}$ \\
\hline $\begin{array}{l}\text { PRANSPORTATION } \\
\text { (ELECT,S } \\
\text { (OIST.) } \\
\text { (RESIO.) } \\
\text { (LG) } \\
\text { (GASOLINE) } \\
\text { (JET FUEL) }\end{array}$ & $\begin{array}{r}5.93 \\
12.53 \\
4.80 \\
2.95 \\
3.27 \\
6.04 \\
4.12\end{array}$ & $\begin{array}{r}5.70 \\
19.28 \\
4.05 \\
3.09 \\
3.27 \\
0.27 \\
4.23\end{array}$ & $\begin{array}{r}5.66 \\
12.51 \\
5.01 \\
3.22 \\
3.27 \\
6.02 \\
4.49\end{array}$ & $\begin{array}{r}5.62 \\
10.49 \\
5.00 \\
2.89 \\
3.24 \\
5.94 \\
4.54\end{array}$ & $\begin{array}{r}5.67 \\
10.81 \\
4.76 \\
3.10 \\
3.09 \\
5.96 \\
4.05\end{array}$ & $\begin{array}{r}5.22 \\
10.73 \\
4.78 \\
2.99 \\
3.27 \\
5.72 \\
9.16\end{array}$ & $\begin{array}{r}5.52 \\
11.91 \\
4.66 \\
3.08 \\
3.06 \\
5.83 \\
3.93\end{array}$ & $\begin{array}{l}5.09 \\
8.68 \\
0.83 \\
2.99 \\
3.49 \\
5.87 \\
0.17\end{array}$ & $\begin{array}{r}5.39 \\
11.93 \\
4.91 \\
2.92 \\
3.27 \\
6.01 \\
0.10\end{array}$ & $\begin{array}{l}5.42 \\
4.96 \\
4.71 \\
2.97 \\
3.27 \\
6.02 \\
9.10\end{array}$ & $\begin{array}{r}5.55 \\
13.30 \\
0.83 \\
3.01 \\
3.31 \\
5.86 \\
9.22\end{array}$ \\
\hline AYERAGE PRICE & 5.18 & 5.67 & 5,32 & 5,83 & 4,81 & 3,86 & 5.04 & 0.48 & 5,13 & 0.42 & 0.90 \\
\hline
\end{tabular}

* LIOUIR GAS IN THE RAW MATERIAL SECTOR INCLUDES LIOUID GAS FEEOSTOCK.

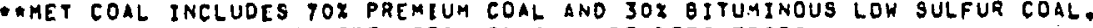

"* INOUSTRIALL SEC:OR HERE DOEg NOT IACLUDE REFINETIES. 
for coal are forecast to be $\$ 1.67$ per million BTU's and $\$ 1.62$, respectively, as shown in Table $I-11$.

The next set of tables refer to the Baseline 2 scenario, or the Baseline scenario based upon monopoly assumptions. Tables $I-12$ and $I-13$ are the executive summary tables in physical units and trillions of BTU's; respectively. Table I-11 shows that for Baseline 2, a total 1985 supply of coal of approximately $1,002.7 \mathrm{million}$ short tons is forecast. The accompanying table, Table $\mathrm{I}-12$, shows that the equivalent of this figurc in BTU'3 is approximately 22.3 quadrillion BTU's. The total supply of energy in 1985, according to PIES for. Baseline 2 , is estimated to be approximately 94.0 quadrillion BTU's .

Table I-14 gives the regional coal production summary by mine type. Again, we are primarily interested in the East, the West, and total U.S. values. The 1985 forecast value for total Eastern production is 672.4 million short tons per year. Western production is shown to be $330.3 \mathrm{million}$ short tons per year. These sum to a total U.S. production figure of $1,002.7$ million short tons of annual mine production.

Table I-15 gives the residential and commercial prices for coal in 1985. The residential price is forecast to be $\$ 40.10$ per ton whilc the industrial price is forccasted to be $\$ 39.03$. The following table, Table I-16, gives the analagous prices on a BTU basis. These prices are $\$ 1.78$ per million BTU's for the commercial sector and $\$ 1.73$ per million BTU's for the industrial sector. 


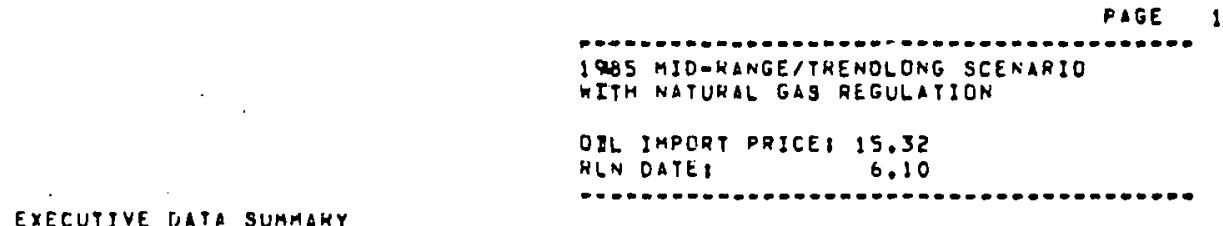

EXECUTIVE DATA SUMAGH

IJNITED STATES TUTAL GKOSS SUPPLY/COHSUHPTION OF ENERGY RESOUREES ENEKËY SUURCES IN STANDARO PHYSICAL UNITS PER YEAR

\begin{tabular}{|c|c|c|c|c|c|c|c|}
\hline SECTOR & $\begin{array}{l}\text { COAL } \\
\text { (MMST) }\end{array}$ & $\begin{array}{c}\text { OIL } \\
\text { (MMB) }\end{array}$ & $\begin{array}{l}\text { GAS } \\
\text { (UCF) }\end{array}$ & $\begin{array}{l}\text { NUCLEAR } \\
\text { (MMAKW'A) }\end{array}$ & $\begin{array}{l}\text { HYOFO, SOLAR, } \\
\text { GEOTHERMAL } \\
\text { (MMMKWH) }\end{array}$ & $\begin{array}{l}\text { SOLAR/GEO } \\
\text { FDSSIL SUAST } \\
\text { TIETUS }\end{array}$ & $\begin{array}{l}\text { TOTAL ELEC. } \\
\text { OISTKIBUTEED } \\
\text { (AKAKWHS). }\end{array}$ \\
\hline $\begin{array}{l}\text { POMESTIC SUPPLY: } \\
\text { (COAL,GAS,ELEC.) } \\
\text { (CRUDE) } \\
\text { (COAPRODUCTS/ASSUC, GAS) } \\
\text { (SYNTHETICS) } \\
\text { (SHALE) } \\
\text { (OIRECT SOLAK/GEO) }\end{array}$ & $\begin{array}{l}1002.71 \\
1002.71\end{array}$ & $\begin{array}{r}3735.53 \\
3262.15 \\
453.22 \\
27.15\end{array}$ & $\begin{array}{r}16730.95 \\
13509.62 \\
3221.32\end{array}$ & $\begin{array}{l}566.49 \\
566.47\end{array}$ & $\begin{array}{l}410.02 \\
395.61\end{array}$ & 119.86 & $\begin{array}{r}3000.94 \\
\quad 3000.90\end{array}$ \\
\hline $\begin{array}{l}\text { (MPORTS: } \\
\text { (CRUDE) } \\
\text { (PRDDUCTS) } \\
\text { (LNG) } \\
\text { (CANADIAN/MEXICAN) } \\
\text { (COAL) }\end{array}$ & 74.000 & $\begin{array}{l}4043.42 \\
2852.61 \\
1170.81 \\
\vdots\end{array}$ & $\begin{array}{l}1850.80 \\
908.81 \\
906.00\end{array}$ & $\cdot$ & & & . \\
\hline TOTAL SUPPLY & 928.71 & 7776.90 & 18585.75 & 566.49 & 410.02 & 119.86 & 3000.90 \\
\hline iAINS $(+) / \operatorname{LOSSES}(-)$ & & 203.64 & & $06.38=$ & $35.70-$ & & $250.63=$ \\
\hline $\begin{array}{l}\text { :ONSUAPTION: } \\
\text { RESIOENIIAL } \\
\text { COMAERTIAL } \\
\text { INOUSTRIAL } \\
\text { TRANSPORIATION } \\
\text { ELECTRICAL, GENEGATION. } \\
\text { SYNTHETICS }\end{array}$ & $\begin{array}{r}1.04 \\
196.56 \\
19.29 \\
118.02 \\
13.66\end{array}$ & $\begin{array}{r}709.40 \\
596.50 \\
2038.46 \\
3900.94 \\
504.07 \\
1 \neq 9.11\end{array}$ & $\begin{array}{l}5269.19 \\
5853.89 \\
9865.91 \\
398.14 \\
2043.43 \\
872.16 .\end{array}$ & & $\begin{array}{l}4.46 \\
5.09 \\
4.80\end{array}$ & $\begin{array}{l}43.39 \\
20.41 \\
56.06\end{array}$ & $\begin{array}{r}828.13 \\
684.23 \\
1211.93 \\
9.05 \\
2728.30 .\end{array}$ \\
\hline POTAL DUMESTIE COMSUMPTION & $: 029.71$ & 7982.93 & 18558.30 & & 10.35 & 119.86 & .00 \\
\hline
\end{tabular}

NOTE, OIL IMPURTS IN MMB/CO 11.06

GAS CONSGMPTION IN THE TKANSPONTATION SECTOR INCLUDES NATURAL GAS TRINSPORTATION LOSSES. INDUSTRIAL CUYSIMPTION INCLIJCES REFINEK FUEL CONSUAPTION.

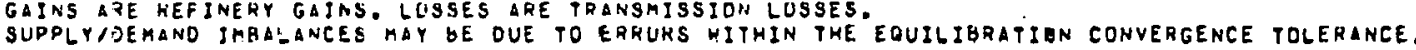


EEECUTIVE DATA SUMAAKY

OIL IAPORT PRIEE, 15.32 RUN DATES 6.10

UNITEE STATES ICTAL GRESS SUPPLYICENSUMPTIUN OF ENEFGY RESJUFCES ENERGY SOURCES IN TRILLIUNS O= HTU'S PEA YEAZ

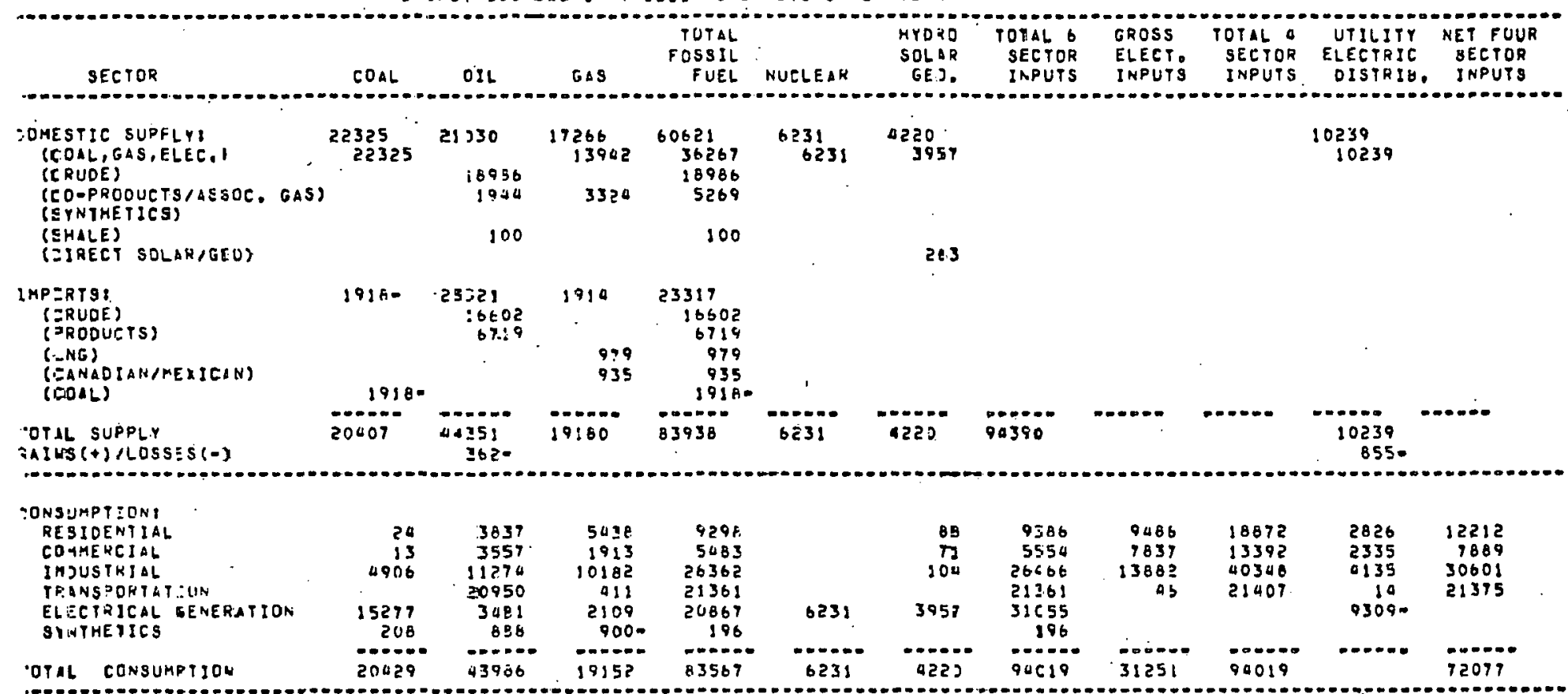

NOTE: GAS COISLMPTION IN THE THATSDURTGTION SECTON INCLUDES NATUKAL GAS TABNSPOFTATION LOSSES.

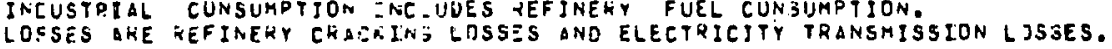

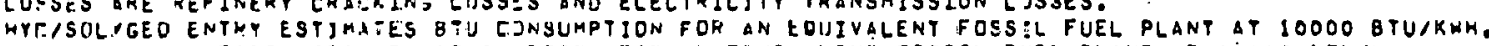
WUCLEAT ENTRY ESTIMATES LTU CONSUAPTIUN FOR AN EOUIVALENT FOSSIL FIJEL PLANT AT 11000 BTU/KWH.

OK AVEFIGE BTU CONVEKBILH OR AGGKEGATES.

AND ELEETHIEITY DEHANE HEPL.CEMEN I AT 16000 BTUS/KWH OF DEMAND IN -BTYS OF

43.50

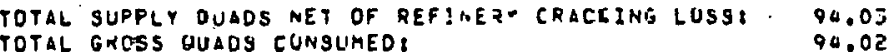




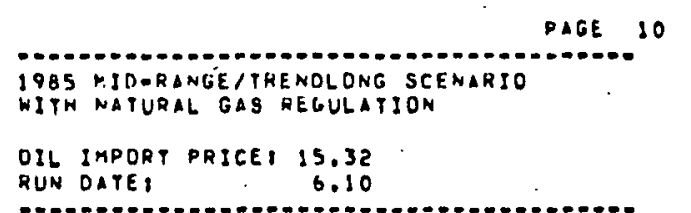

COAL REGIUNAL PRUDUCTION SUMMARY IN MILLLON GMORT TONS PER YEAR (BY MINE TYPE)

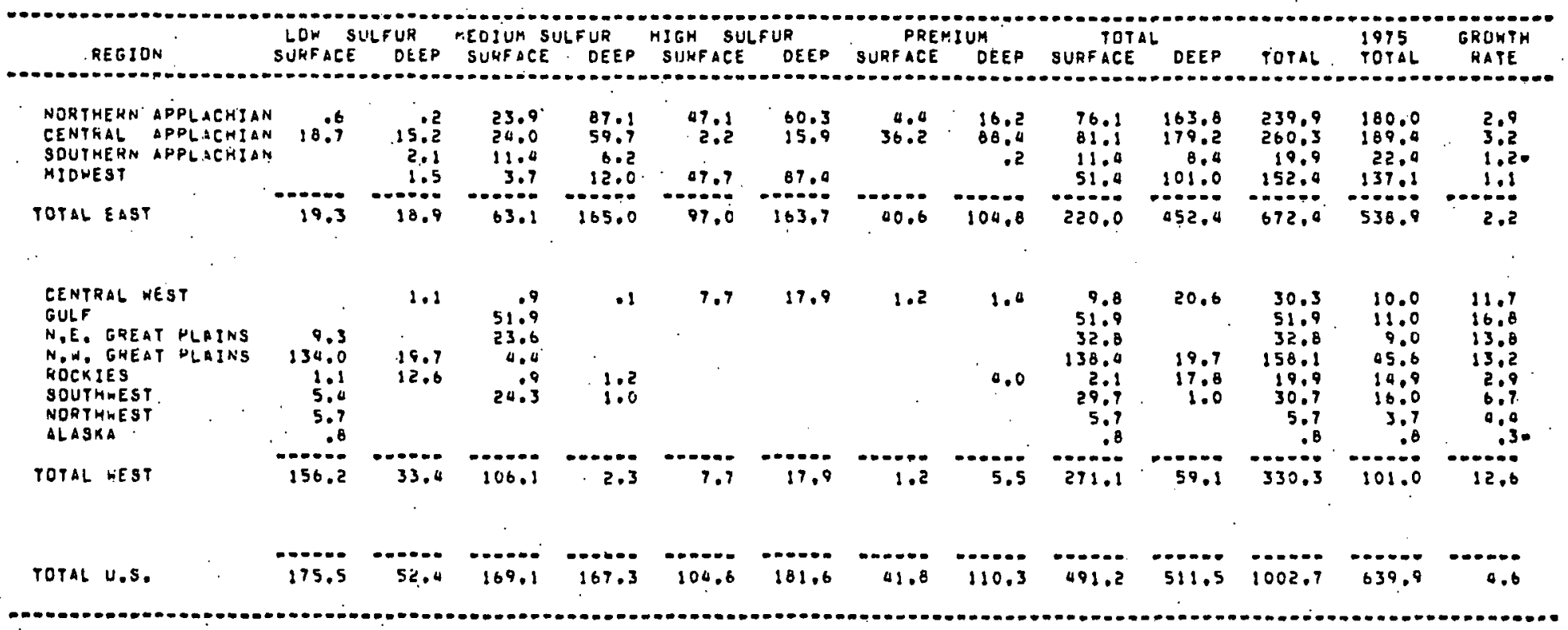


TABLE I -15

PAGE 5 I

1985 HID-RANGE/TAENOLONG SCENAFIO

HITH NATURAL GAS REGULATION

\begin{tabular}{l} 
OIL IMPORT PRICEI 15,32 \\
RUN DATE: \\
\hline O
\end{tabular}

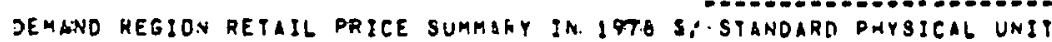

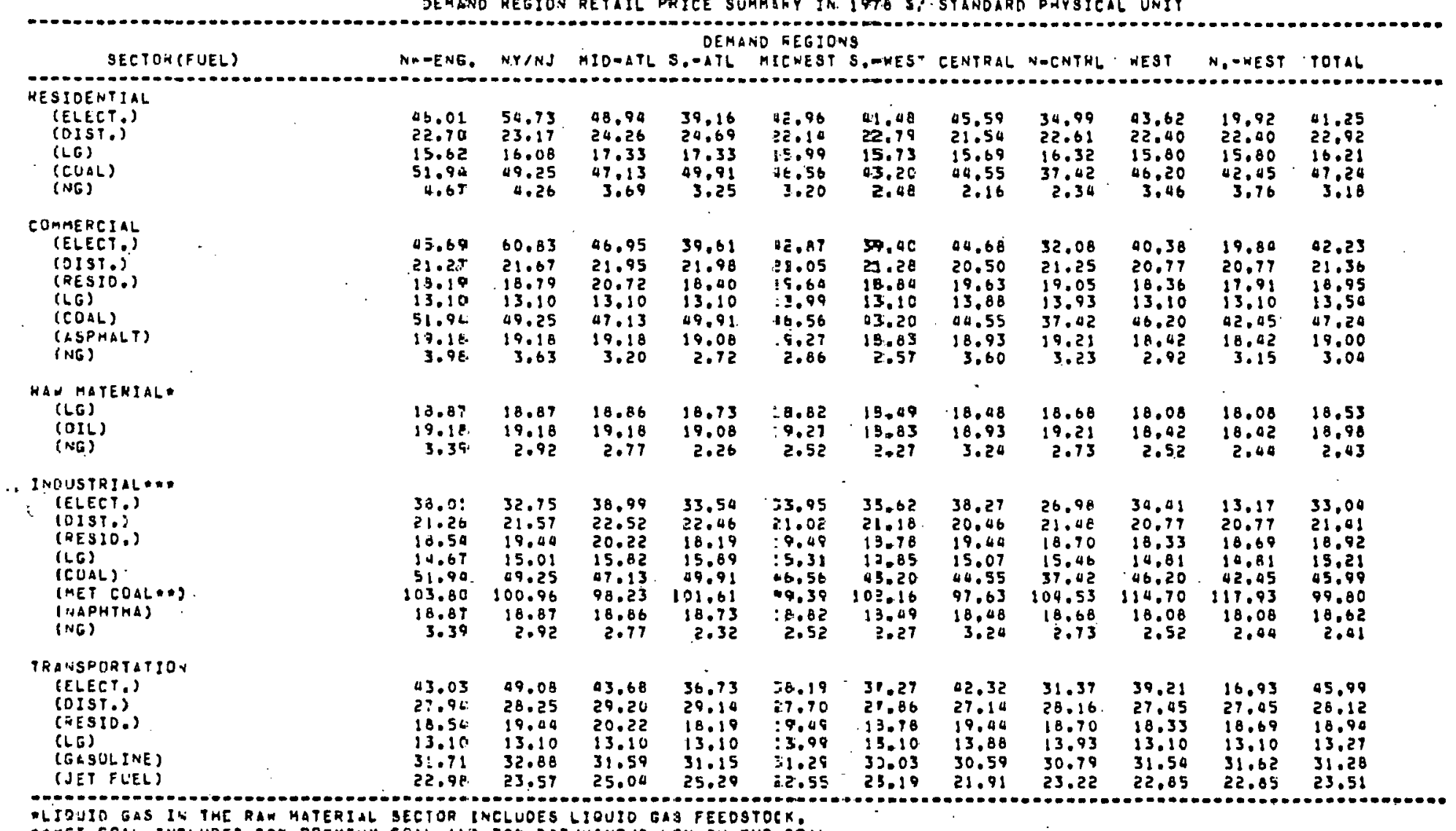

- LTUIO GAS IL THE RAW HATERIAL BECTOR INELUOES LIOUIO GAS FEEOSTOCK.

MINDUSTRIAL. SECTOR MERE DUES NDT INCL JOE REFINERIES. 
PAGE 22

1985 MID-RANGE/TRENOLONG SCENARIO

WITM NATURAL GAS REGULATION

OIL IMPORT PRICE! 15,32

RUN DATE: 6.10

OEMAND REGION AVERAGE RETAIL PKICE SUMMARY IN I9TA SIMILLION ETUS

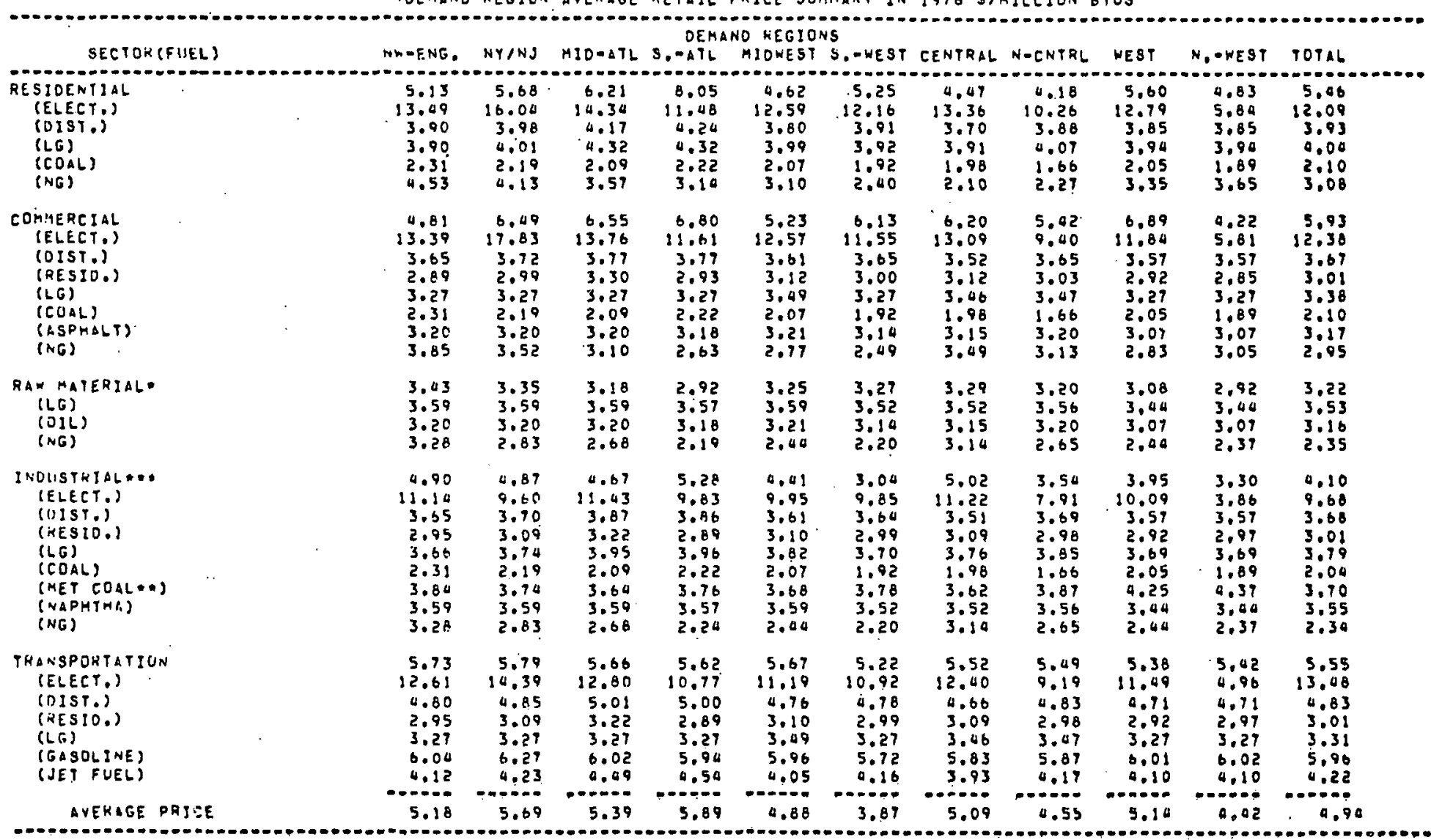

- LIRUID GAS IN THE RAN MATERIAL SECTOR INCLUDES LIOUID GAS FEEDSTOCX.

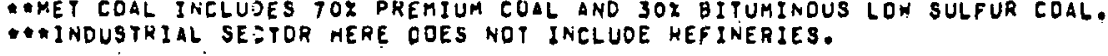


The Total Divestiture Run

We are interested in comparing to the baseline runs presented above, a run representing the situation with total divestiture. Total divestiture is represented as an equalization of rates of return in the model since differences in relevant ownership characteristics would no longer exist. Further, we have added a slight ( $10 \%$ each) increase in capital and labor costs to simulate the increased costs to firms and a less than optimal based organization. Tables I-17 through I-2I present the PIES tables which are comparable to the ones presented for the PIES run representing the baseline cases.

Table I-17 shows that, for the total divestiture run, a tota1 1985 supply of coal of approximately $1,014.7$ million short tons is forecast. Referring to Table I-18, this domestic supply figure is roughly equivalent to 22.5 quadrillion BTU's. The total divestiture run shows a total supply of approximately 94.1 yuadrillion BTU's.

The coa1 regional production summary, Table I-19, shows production by mine type. The 1985 forecast value for total Eastern production is 680.1 million short tons. For the West, this figure is 334.5 million short tons of annual mine production. This gives a total U.S. production figure in 1985 of $1,014.7$ million short tons.

Table I-20 shows that the residential and commercial prices for coal in 1985 are expected to be $\$ 39.62$ per ton, with an industrial price of $\$ 38.56$. Table I-21 shows the same figures in BTU's. Commercial and industrial prices for coal are forecast 


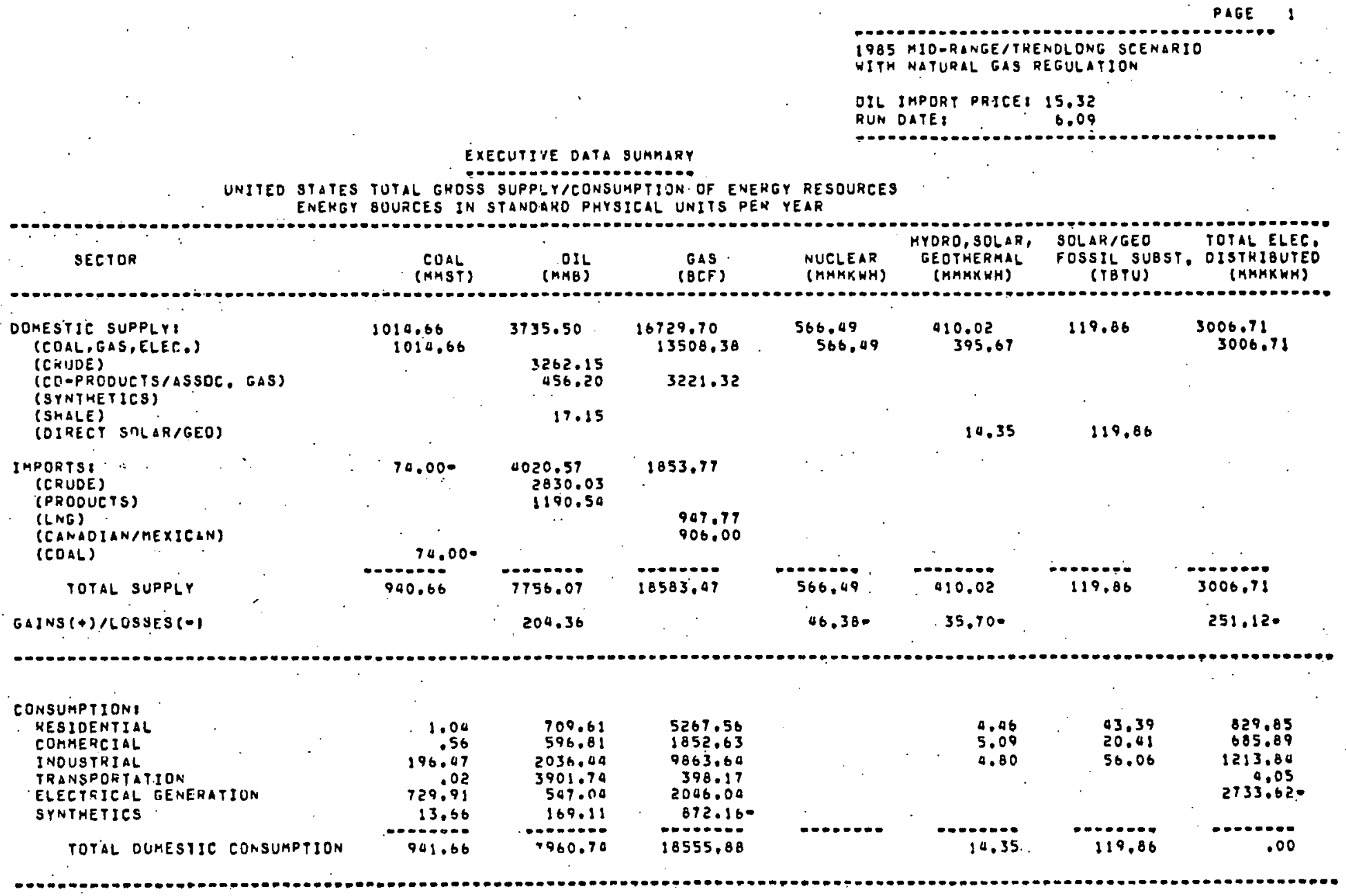

NOTE: OIL IMPORTS IN MAZ/CO 11.02

GAS CDNSUMPTION IN THE TKANSPORTATION GECTOR INCLLDES NATURAL GAS TRANSPORTATION LOSSES.

INTUSTRIAL CONSUMPTION INCLUDES REFINERY FUEL CONSUMPTION.

GUPPL TODEAND IMBALANCES MAY BE OUE TO ERRORS MITHIN THE EQUILIBRATION CONYERGENCE TOLERANCE. 
PAGE 2

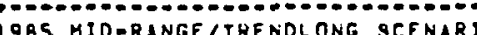
WITK NATURAL GAS REGULATION

EXECUTIVE DATA SUKMARY

OIL IKPORT PRICE, 15.32 RUN DATEI PRICET T., 6.00

UNITEO STATES TOTAL GROSS SUPPLYTCONSUMPTION DF ENEREY RESOURCES ENERGY SOURCES IN TRILLIOHS OF BTU AS PER YEAR

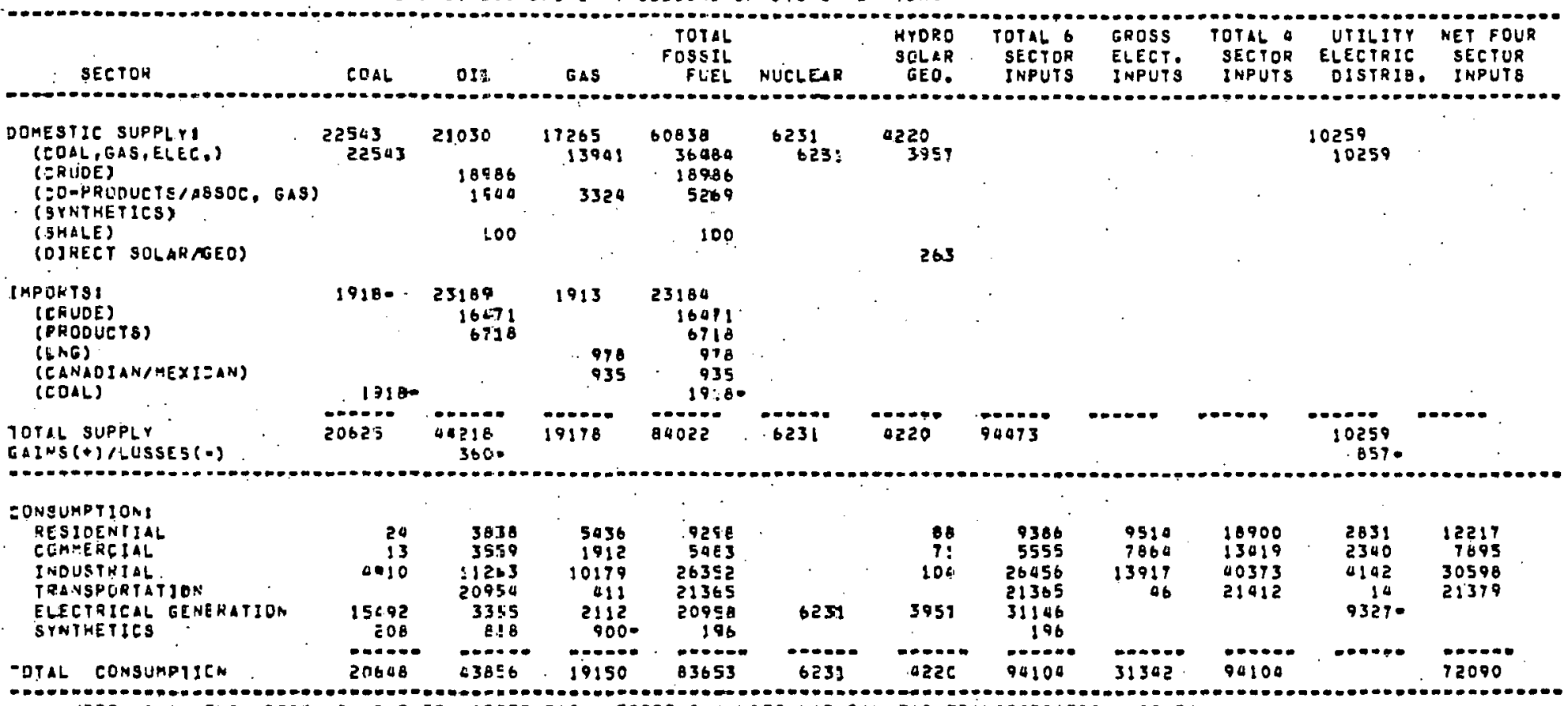

NOTE: GAS CENBUMPTIUN IN THE TRINSPERTATION BECTOR INCLUDES NATJRAL GOS FRAMSPDRTAYION LOSSES.

LOSSES ARE REFINERY CHIEKING LOSSES AND ELECTRICITY TRANS AISSION LDSSE.

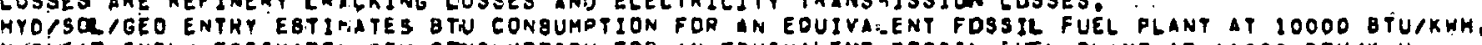
NUELFAR ENTKY ESTIMATEE BTY CONSUMPTION FOR AN EZUIVALENT FOSS I IUEL PLANT AT IIDOO BTURKWH.

OH IVEZAGE GTU CONVERSION OF AEGREGATE

DIRECI SOLARIGEO SUP PL INCLUCES FOSSIL FUEL DEMINO REPLATEMENT IN T8TUS OF 119.86

TOTAL SUPP.Y OUADS NET OF HEFINERY CRACKING LOSS:

TOTAL GROSS JUADS CONSUMEDI 
TABLE I- 19

1985 MIO-RangejiKEnOLONG SCENARjo

1985 MIDPRANGE/TKENDLONG SCEMAI
WITH NATURAL GAS REGULATION

OIL IMPORT PKICEI 15.32
RUN OATE:
6.09

RUN OATE:

COAL REGIUNAL PRODUCTION SUMMARY IN MILLION SHORT TONS PER YEAR (BY MINE TYPE)

\begin{tabular}{|c|c|c|c|c|c|c|c|c|c|c|c|c|c|}
\hline REGION & $\begin{array}{l}\text { LOW } \\
\text { SURFACI }\end{array}$ & OEEP & $\begin{array}{l}\text { MEDIUM S } \\
\text { SURFACE }\end{array}$ & $\begin{array}{l}\text { ULF UR } \\
\text { DEEP }\end{array}$ & $\begin{array}{l}\text { KIGH SU } \\
\text { SURFACE }\end{array}$ & WUR & $\begin{array}{r}\text { PRE } \\
\text { SURFACE }\end{array}$ & $\begin{array}{l}\text { IIUK } \\
\text { DEEP }\end{array}$ & $\begin{array}{l}\text { TOT } \\
\text { SURFACE }\end{array}$ & DEEP & TOTAL & $\begin{array}{l}1975 \\
\text { TOTAL }\end{array}$ & $\begin{array}{l}\text { GROHTK } \\
\text { RATE }\end{array}$ \\
\hline $\begin{array}{l}\text { NORTHERN APPLACHIAN } \\
\text { CENIRAL APPLACHIAN } \\
\text { SDUTHERN APPLACHIAN } \\
\text { MIOWEST. }\end{array}$ & 18.9 & $\begin{aligned} 15: 2 \\
2: 3 \\
2: 1 \\
1.4\end{aligned}$ & $\begin{array}{l}23.1 \\
24.0 \\
11.4 \\
3.3\end{array}$ & $\begin{aligned} 82.0 \\
58.6 \\
6.2 \\
12.8\end{aligned}$ & $\begin{array}{r}50.5 \\
2.2 \\
06.3\end{array}$ & $\begin{array}{r}57.5 \\
15.6 \\
102.6\end{array}$ & $\begin{array}{r}4.4 \\
35.5\end{array}$ & $\begin{array}{r}16.2 \\
89.1 \\
.2\end{array}$ & $\begin{array}{l}78.7 \\
80.9 \\
11.4 \\
49.5\end{array}$ & $\begin{array}{r}156,3 \\
178,6 \\
8,9 \\
116,9\end{array}$ & $\begin{array}{l}235.0 \\
259.0 \\
19.9 \\
166.4\end{array}$ & $\begin{array}{l}180.0 \\
189.4 \\
22.4 \\
237.1\end{array}$ & $\begin{array}{l}2,7 \\
3,2 \\
1,2 . \\
2,0\end{array}$ \\
\hline TOTAL EAST & 19.3 & 18.9 & 61.8 & 159.9 & 99.0 & 175.8 & 39.9. & 105.5 & 220.0 & 460.1 & 680.1 & 538,9 & 2.4 \\
\hline $\begin{array}{l}\text { CENTRAL WEBT } \\
\text { GULF } \\
\text { N.E. GREAT PLAINS } \\
\text { NHW GREAT PLAINS } \\
\text { ROCRIES } \\
\text { SOUTHWEST } \\
\text { NOHTMNEST } \\
\text { ALASKA }\end{array}$ & $\begin{array}{r}1.1 \\
100.8 \\
1.7 \\
5.4 \\
5.7 \\
.8\end{array}$ & $\begin{array}{l}96.5 \\
13.4\end{array}$ & $\begin{array}{r}51.9 \\
32.1 \\
5.0 \\
22.9\end{array}$ & $\begin{array}{l}1.2 \\
1: 0\end{array}$ & 7.7 & 15.6 & 1.2 & 1.4 & $\begin{array}{r}9.8 \\
51.9 \\
33.1 \\
106.2 \\
2.6 \\
28.1 \\
5.7 \\
.8\end{array}$ & $\begin{array}{r}18.3 \\
18.6 \\
1,0\end{array}$ & $\begin{array}{r}28.0 \\
51.9 \\
33.1 \\
160.6 \\
21.3 \\
29.1 \\
5.9 \\
.8\end{array}$ & $\begin{array}{r}10.0 \\
11.0 \\
9.0 \\
05.6 \\
10.9 \\
16.0 \\
3.9 \\
.8\end{array}$ & $\begin{array}{l}10.8 \\
16.8 \\
13.9 \\
13.7 \\
3.6 \\
6.2 \\
0.0 \\
.30\end{array}$ \\
\hline TOTAL WEST & 155.0 & 33.0 & 113.9 & 2.3 & 7.7 & 15.6 & 1,2 & 5.5 & 278.2 & 56,3 & 330.5 & 101.0 & 12,8 \\
\hline roTAb U.s. & 174.7 & 51.9 & 175.7 & 162.1 & 106.8 & 191.4 & 41,1 & 111.0 & 498.2 & 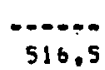 & 1019,7 & 639.9 & $a, 7$ \\
\hline
\end{tabular}


TABLE I -20

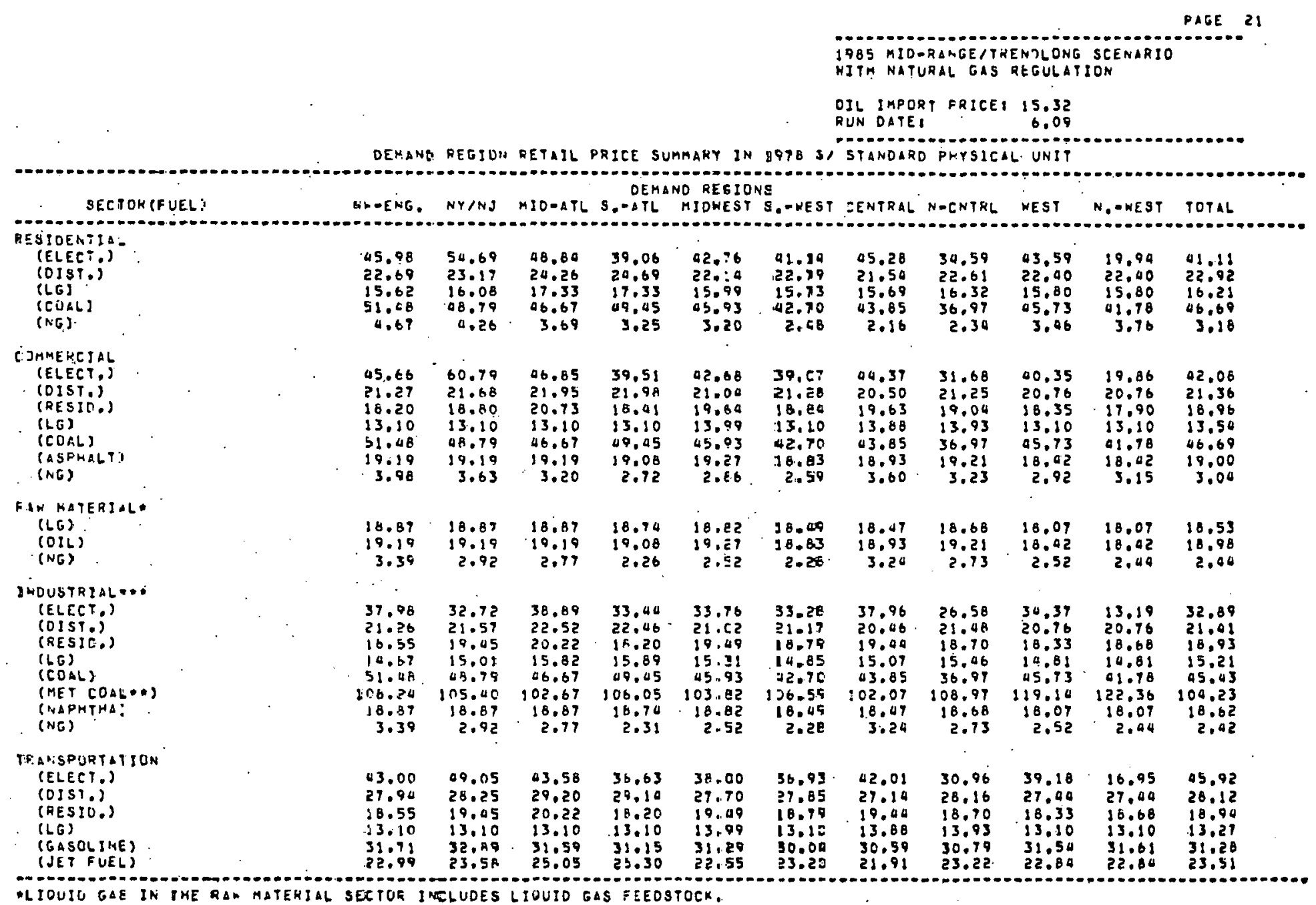

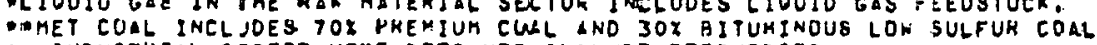

... INDUSTKIAL SECTOR HERE DOES NOT INELUDE REFINERIES. 
PAGE 22

1985 MID-RANGE TTRENDLONG SCENARIO

WITH NATURAL GAS REGULATION

OIL IMPORT PRICEI 15,32
RUN OATE:
R.09

DEMAND KEGIUN AVERAGE RETAIL PHICE SUMAARY IN 1918 SIMILLION RTUS

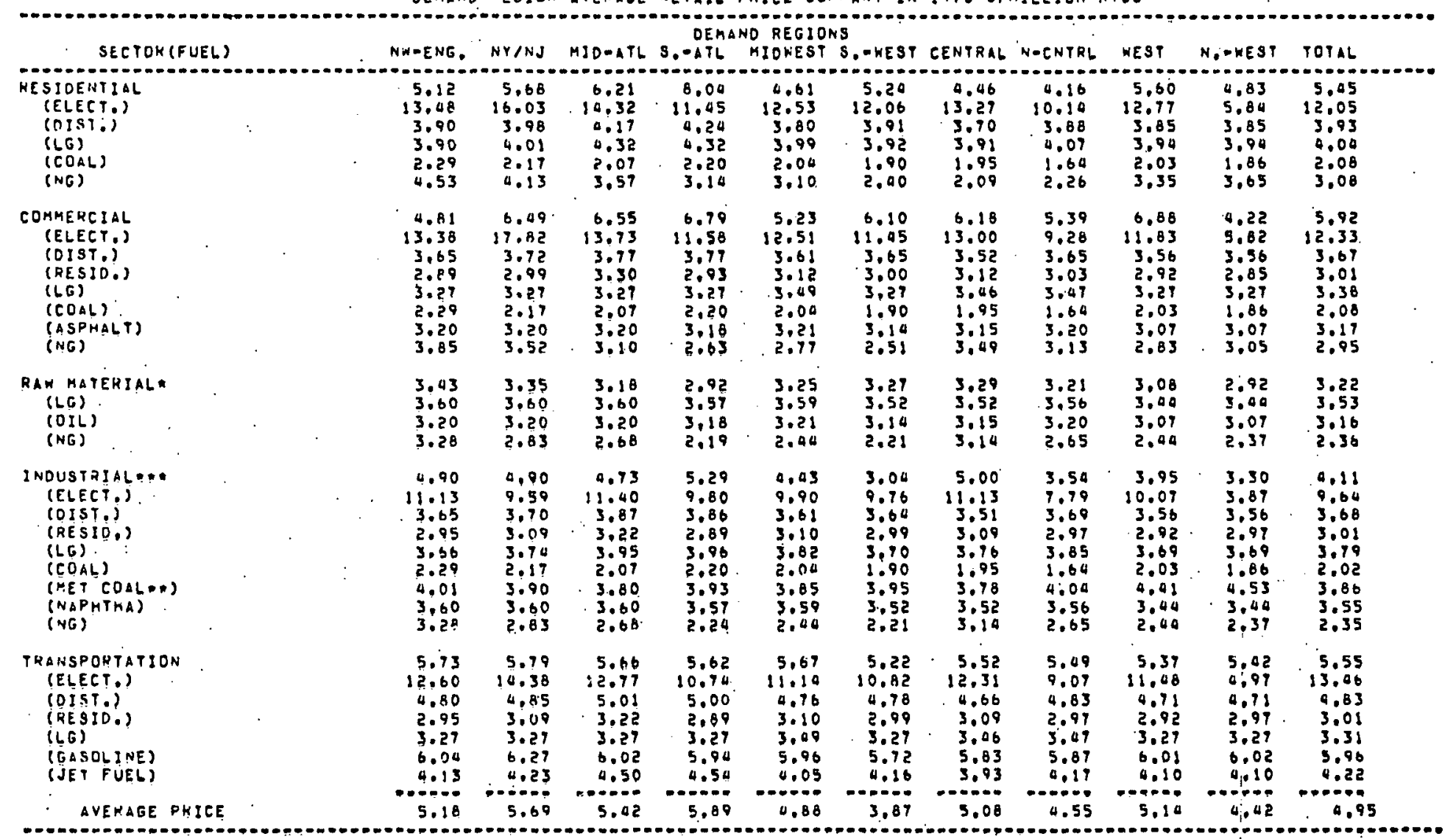

- LIUUID GAS IN THF RAW MATERILL SECTOR JNELUDES LIOUIO GAS FEEOSTOCK.

- MET CDAL INCLUOER TOX PREMIUN CUAL AND 3OX BITUMINOUS LOK SULFUR COAL,

MINOUSTRIAL SECTLP HERE DOES NOT INCLUDE FEFINERIES. 
to be $\$ 1.77$ per million BTU's and $\$ 1.71$ per million BTU's, respective1y.

The Restraint Scenario

The PIES runs reflecting the Restraint scenario are not available as of this report. However, the ones which are forthcoming are set up to allow for an increase of the mid-range Baseline 1 rates of return by 2 percentage points each. The rationale is that the establishment of rcstraint by law will effectively erert barriers to entry in the coal industry which specifically bax the most likely potential entrants (oil firms). The direct impact of this, as interpreted in the model, would be the increase in ROR for both oil and non-oil. Both ownership classes of existing firms gain and are able to raise ROR without attracting entrants. We expect this run to show that, relative to Baseline 1 , restraint will cause less quantity and higher prices in 1985.

\section{Comparison of Sconarios}

Table I-22 presents the various runs and their assumptions. As mentioned before, because of other priorities, DOE cannot run the requisity PIES runs for a11 of these runs at this time. We do have PIES results for some of the more basic runs, however. The rest will be presented in our addendum. 
TABLE I -22

SUIAMARY OF RUN ASSUMPTIONS

\begin{tabular}{|c|c|c|c|c|}
\hline \multirow[b]{2}{*}{ Scenario } & \multirow[b]{2}{*}{$\begin{array}{l}\text { ROR } \\
\text { Oi } 1 \\
\frac{\circ}{6} \\
\end{array}$} & \multirow[b]{2}{*}{$\begin{array}{c}\text { ROR } \\
\text { Nonoi } 1 \\
\frac{\%}{6} \\
\end{array}$} & \multicolumn{2}{|l|}{$\div \Delta$} \\
\hline & & & $\begin{array}{c}\text { Oil Capital } \\
\text { Costs }\end{array}$ & $\begin{array}{l}\text { Oil } \\
\text { Wages }\end{array}$ \\
\hline Baseline 1 & & & & \\
\hline Lower & 1 & 8 & -- & -- \\
\hline Mid & 3 & 8 & -- & - \\
\hline Upper & 8 & 8 & $\cdots$ & -- \\
\hline Baseline 2 & & & & . \\
\hline Lower & 8 & 8 & -- & - - \\
\hline Mid & 10 & 8 & -- & - \\
\hline Upper & 13 & 8 & -- & - \\
\hline Total Dive & & & & \\
\hline Lower & 8 & 8 & +5 & +5 \\
\hline Mid & 8 & 8 & +10 & +10 \\
\hline Upper & 8 & 8 & +20 & +20 \\
\hline Restraint & & & & \\
\hline Lower & 3 & 8 & -- & -- \\
\hline Mid & 5 & 10 & - & $\cdots$ \\
\hline Upper & 8 & 13 & -- & -- \\
\hline
\end{tabular}


We compare three runs here. We compare Baseline 1 to Total Divestiture and Baseline 2 to Total Divestiture. For Baseline 1 and Total Divestiture the midrange cases are presented while for Baseline 2, the upper case is presented. The results of these runs are summarized in Table I-23. .

As Table I-23 clearly indicates, the results are deperdent upon one's assumption about the baseline. If Baseline 1 is. believed, i.e., synergism and growth maximization are possibilities, then the imposition of Total Divestiture will lower quantities of coal avaflable in 1985 and increase the price. If one believes that Baseline 2 is more realistic, i.e., monopoly power allows higher rates of return to be earned by oil companies on their coal assets, then the opposite result is obtained. Comparing Total Divestiture to Baseline 2 yields an increase in coal available and decrease in price.

The quantity differences are smali and roughly symmetric in the two compaxisons. The change in quantity under Total Divestiture is approximately $\pm 1.5 \%$. For prices, however, going from Baseline 1 to Total Divestiture yields approximately a $6 \%$ increase in the industrial price of coal. Converscly, from Baseline 2 to Total Divestiture would only yield approximately a $10 \%$ decrease in price. 


\author{
TABLE I -23
}

SUMMARY OF PRICE AND QUANTITY

FORECASTS FOR 1985 UNDER

ALTERNATIVE ASSUMPTIONS

\begin{tabular}{|c|c|c|}
\hline Scenario & 1985 Production & 1985 Ind. Price \\
\hline Baseline 1 & $1,029.7$ & $\$ 36.49$ \\
Base1ine 2 & $1,002.7$ & 39.03 \\
Total, Divestiture & $1,014.7$ & 48.56 \\
\hline
\end{tabular}


VOLUME I

Section 2 


\section{THE IMPACT OF PETROLEUM INDUSTRY \\ HORIZONTAL DIVESTITURE ON THE \\ COAL MARKET \\ VOLUME I, SECTION 2 \\ FINAI, RE PORT}

Durald L. Zimmerman

Lee $\mathrm{H}$. Dymond

Robin L, Marris

Submitted to:

Department of Energy

Division of Competition Analysis

12 th and Pennsylvania Avenue, N.W.

Washington, D.C.

Submitted by:

Synergy, Inc.

233718 th Street, N.W.

Washington, D.C. 20009
Subcontractor:

The Department of Economics University of Maryland College Park, Md. 20740

\section{May $8,19 \% 8$ \\ Revised: September 15, 1978 \\ Contract \#EC-77-C-01-8606}

The views and conclusions contained in this document are those of the authors and should not be interprcted as necessarily represcnting official policies of the U.S. Government. 


\section{TABLE OF CONTENTS \\ VOLUME I, SECTION 2 \\ THE . REPORT}

Page

\section{SECTION 2}

CHAPTER 2-1 THE ECONOMICS OF DIVESTITURE . . . : : 2-1

The Economic Implications of Legislative

Divestiture ............ . . 2-2

C.HAPTER 2-2 THE INVESTMENT AND GROWTH. BEHAVIOR OF SUCCESSOR COMPANIES COMPARED TO DIVESTED

COMPANIES ................. . . 2-17

The Theory of the Growth of the Firm Applied

to the Divestiture Problem . . . . . . 2-18

Optimal Depletion Theory . . . . . . . . 2-25

Competitive Effects . . . . . . . . . 2-33

Conclusions .. . . . . . . . . . . . . . 2-38

Bibliography . . . . . . . . . . . 2-42 
CHAPTER $2-1$

THE ECONOMICS OF DIVESTITURE

There are four main ways in which divestiture may affect the behavior or performance of the coal industry in directions that are relevant to this study. The first is through so-called "synergistic" effects, e.g., useful technology that might fail to be transferred to coal from oil if oil companies were not present in the coal industry. The second is effects of possible differences in the investment and growth policies of oil companies owning coal reserves compared to the corresponding policies of companies that might succeed them. The third is the effects on depletion rates and the fourth is through effects on the competitive behavior of the coal industry as a whole resulting from the presence or absence of oil companies. Following a general discussion, these four elements are discussed in turn.

How should the "eviction" of a certain type of company from a certain industry affect the subsequent performance of that industry? Subsequent performance can be significantly affected if, and only if, the companies that succeed the evicted companies have both the desire and the means to behave/perform differently from the evicted companies, in this case; coal-owning oil companies. A considerable portion of traditional economic theory has nothing whatsoever to say on this question, as it assumes: that the behavior or performance of firms and industries is determined mainly by conditions that transcend any motives that firms of different types might or might not possess. 
There exists, however, an alternative group of economic theories which may be referred to as "discretionary" or "managerial" theories, that do provide some answers to these questions. These theories can be combined with relevant aspects of traditional theory to provide a useful framework for the divestiture problem.

The Economic Implications of Legislative Divestiture

Divestiture prohibits a class of firms from continuing to carry on a certain type of busincss. It may requirc that all firms of the class divest themselves of their existing assets in that business, or it may only prevent future acquisitions. The first kind of action may be called divestiture proper, the second, restraint. Assuming that the type of business in question (e.g., the coal business) is profitable, and also that other classes of firms will not legally be restrained from entry, one may assume that in the case of divestiture proper some other firms--either already in the industry or from outside--will wholly or partly seek entry into the divested activity. In the case of restraint, some part of any expected future growth of the industry that would otherwise have been accounted for by restrained companies, e.g., oil-owned coal companies, will be taken up by other organizations either from within or outside the industry. In the case of either divestiture or restraint it is convenient to speak of organizations that may replace the actual or potential coal production of oil-owned coal companies as "successor" firms. The possible differences in the policies of successor companies, 
as compared with either oil companies or existing non-oil coal companies are obviously crucial elements in this inquiry.

Private industrial corporations are free to vary their policies with respect to investment and output if, and only if, circumstances are such as to endow them with economic discretion. $1 /$ Divestiture or restraint can affect policies, therefore, only if discretionary circumstances are already present or are. created by the legislation itself. Otherwise divested organizations and successor organizations must behave identically and neither divestiture nor restraint will significantly affect the coal market.

Necessary conditions for divestiture to have significant economic effects are not however sufficient conditions. It is also necessary that divested and successor firms not only have the means to behave differently from one another but also wish to do so. In addition to the economics of discretionary behavior, we are also required to consider the general theory of business motivation; in particular, as it predicts that the motives of one type of corporation, such as an oil company in the coal business, may differ or not differ from that of another type of business such as an independent coal operator. $\underline{2}$

1/ "Economic discretion" is said to exist when firms who pursue policies other than those which strictly maximize the financial returns to stockholders can at least survive and probably prosper. See 0. E. Williamson, The Economics of Discretionary Behavior, 1964.

2/ For background, see Williamson, ibid., and/or Marris, "A. Model of the Managerial Enterprise," Quarterly Journal of Economics $(1963)$. 
Let us assume that oil companies have the necessary discretion to choose and execute policies that could differ significantly from those of successor companies. They are conglomerates by virtue of their diversification into coal and other activities; their main business, oil, is conducted under conditions far from pure competition, and the coal business itself, though more competitive than the oil business, is more appropriately described as "low-1eve1 oligopoly" $3 /$ than perfect competition. Therefore, with respect to investment, technological, and output decisions, oil companies in the coal industry are by no means confined to a narrow framework; for example, they are to a considerable extent free to choose whether to devote available cash to developing their coal interests quickly, or alternatively to delay development while employing the same cash resources in non-coal activities or in portfolio investment. They may choose different depletion rates (see discussion below) from other owners or lessors of coal reserves, a type of action that is, of course, the obverse of different investment policies.

Oil companies may also possess different technological resources from other companies and might have, in this respect, the means for performance different from non-oil-owned coal companies in the coal industry. A difference in technological. orientation and know-how among oil companies could be transferred

3/ A lechnical expression for conditions in which the effective number of producers in a defined market is too large for sophisticated cooperation but small enough relative to the relevant conditions, that simple interdependent behavior will occur. 
through direct investment into coal mining technology in their coal subsidiaries; divestiture would bar this transfer and thus affect the technological development of the coal industry. The implications of this point, which is based on the idea of "synergy" between the technological, administrative and commercial functions of business corporations is further discussed below. Its significance depends on the extent to which the technology in question, if barred from transfer by the directinvestment route would not, in the event of divestiture, eventually find its way into the coal industry by alternative routes.

It has also been argued that oil companies have, in general, access to either larger and/or cheaper supplies of capital than successur companies might have. If it is true that oil companies have access to relatively cheaper supplies of capital than successor companies, non-divestiture will affect coal industry performance only if the cheaper capital results in investments in coal which would yield lower expected rates of return than would be required by successor companies. To assume that oil companies would behave in this way is a larger step than is sometimes supposed, and by no means necessarily a logical step. There is no presumption that mere possession of cheap capital is reason enough for undertaking relatively low-yielding investments when, as is evidently the case for oil companies, other investment outlets are also available. For example, if oil companies were strictly motivated to maximize the interests of their stockholders, it might be argued (particularly if 
"synergistic" effects are discounted) that if oil companies have excess cash, this should be returned to stockholders to reinvest according to their individual expectations and interests

1 ternatively, if management believes that it has access to a range of better investment opportunities (including skilled portfolio management) than do individual stockholders acting alone, ratiner than undertake low-yielding investments in coal, it might be better. for stockholders of the companies to invest in otler industries or in portfolios. Consequently, if oil companies do, and non-oil comvanies do not, in fact, strictly pursue policies which maximize stockholder welfare, divestiture would have no economic impact. There is, however, some empirical evidence that large corporations, although considerably influenced by stockholder interests, do not pursue policies that strictly maximize such interests. Any investigation of the economic impart of divestiture must, therefore, take account of alternative objectives. It is therefore necessary, in order to study thc divestiture problem, to combine appropriate elements of "traditional" economic theory with elements from the theories that have developed over the past twonty years that are especially concerned with the implications of the presence of multiple objectives in the decision-making and general behavior of large business corporations.

4/. See, for example, W.J. Baumol, Business Behavior Values and Growth, 1959; R. Marris, op. cit.; Williamson, op. cit.; R. Marris, The Economic Theory of "Managerial" Capitalism, Chaps. 2 and 5, 1964; Dennis Mueller, "A Theory of Conglomerate Mergers," Quarterly Journal of Economics, 1969; Dennis Mue11er, "A LifeCycle Theory of the Firm," Journal of Industrial Economics, 1972; Dennis Mueller and Henry. Grabowski, "Managerial and StockholderWelfare Models of Firm Expenditures," Review of Economics and Statistics, 1972 . 
As regards the "traditional" elements, the appropriate aspects relate to (i) price formation and (ii) investment and growth decisions, which will now be discussed in that order.

The question of price formation is essentially the question of the determination of the supply curve; that is, the schedule of the outputs of different types of coal that will be produced on alternative assumptions concerning the prices the different grades will command. In economic theory concerned with less than competitive conditions, firms do not "take" prices but rather "make" them, so no supply curve strictly exists. But in the case of "low-level oligopoly," it is possible to obtain a reasonable approximation to a realistic characterization of the general situation by assuming that once the price level has been (oligopolistically) determined, firms will behave as if they were "price takers" so that a supply curve may be specified. A complex supply curve is built into PIES, on the assumption that as progressively higher prices are assumed, new hypothetical coal mines (with specified production-cost characteristics) will become economic to operate, and will place on the market predetermined quantities of coal of a specified grade and geographical location.

In traditional theory a person who owns or leases a natural resource will determine the time-path of output from the reserve (and hence the investment policy) on the criterion of maximizing the discounted present value of expected future net cash flow. Such a person or institution, will not pay for a leasc or for 
ownership unless maximized discounted present value exceeds the cost of acquiring the right by an amount that represents a greater return than any alternative use of investment funds. After a right has been acquired, however, if economic circumstances move adversely to make the discounted present value lower than had been anticipated, some production will continue unless the discounted present value falls to zero. The National Coal Supply Model contains a rate of return (ROK) that is to be regarded as a specific element in long-run unit costs, The supply of any grade of coal predicted to be offered for salc at a specified price is calculated on the assumption that any mine that offers a positive discounted present value on the assumed ROR will in fact be brought into or kept in operation, and that from it, a fixed output (determined by assumed capacity) will be offered for sale. ${ }^{5 /}$ The model then specifically predicts the entire supply curve of the coal indistry appropriate to the indicated rate of return. A lower rate of return will shift the supply curve downwards, a higher rate upwards. $\underline{6}$ The PIES rate of return should be regarded as a "real" rate of return such as would rule if no long-term inflation of prices and costs in the economy at large were generally anticipated: the prices predicted on the supply curve are therefore to be regarded as inflation-free prices: they predict, in effort, the movements

5/ PIES abstracts from short-term output decisions. It also docs not deal with optimal depletion paths through time, but rather predicts output for single years, such as 1985, without considering whether an increased output in $1985 \mathrm{might}$ imply higher operating costs and hence lower output at some point in the future.

6/ The baseline ROR in PIES is eight percent. At the present 
of coal prices relative to other prices on whatever assumptions are being investigated in the model at the time.

Turning now to the investment and growth decisions, we note that in recent developments of traditional theory it has become customary to assume that the sole criterion for such decisions will be the maximum welfare of the owners of the business. If

6/ (Continued) time, prices are rising almost as fast as the yield on long-term government bonds, so that it could be argued that the "real" riskless discount rate of the economy was zero. or negative. There are several reasons, however, why this type of calculation tends to overstate the nominal rate of interest that would be established if all inflationary expectations were eliminated. Firstly, it is probable that even today people do not fully transfer current inflation in to long-term investment decisions, i.e., they make such decisions on the assumption (or perhaps the hope) that at some time in the future inflation rates will decline. Secondly, the theory of investment that relies upon calculating the real rate of interest as the excess of the nominal interest rate over the expected inflation rate is incomplete because it fails to consider adequately the portfolio-holding aspect of investment decisions. Any person or organization with money to place must choose exhaus tively between holding it as cash, short-term interes.t-bearing deposits or loans, long-term loans, real property or some other direct investment. In times of brisk inflation, however, supplies of the 1 ast-mentioned group available to the typical investor (individual, institutional or corporate) are limited, if only because one of the most important elements in inflation is the rising cost of 1 abor and because, in the absence of slavery or conscription, there is no person or institution in Western society legally empowered to hoard this commodity. Other inflation hedges, such as factories, commodities or coal mines, are subject to considerable specific risks. For example, although the price of coal and of energy in general continues to rise, the particular coal mine in which one has invested may be destroyed by an explosion. Many individuals who speculated in commodities in the inflation waves of the early 170 s subsequently suffered losses, and are now apparently prepared to place their money in fixedinterest securities in the belief that, although they may earn small or even negative real returns, they are doing better in relation to thejr own forecasting capacities and risk aversions than they could by any other course of action. It is therefore difficult to estimate an appropriate real interest rate for the U.S. economy at the present time, because the foregoing considerations are unquantifiable. However, it is worth noting that during the period 1952-62, which was a period of exceptionaliy low inflation in the U.S., the average excess of the yield on longterm government bunds over the average inflation rate of consumer (Continued on next page) 
a11 corporations at all times adopt this criterion, except for the argument based on the possibility of synergistic effects, a change in ownership or control brought about by divestiture should have little effect. For the reasons already set out, an oil company should treat its coal reserves as a portfolio investment and when an oil company appraises investment projects associated with the development of production from its coal reserves, it should not therefore appraise such projerts at any rate of return lower than the best return its stockholders could obtain (or thc mallagement could obtain on the stockholders' hehalf) in allernative uses--a theorem which, we have seen, applies equally forcefully whether or not oil companies have access to cheaper sources of capital than successor firms would have.

6/. (Continued) prices was about two percent. Since bond yields were rather stable throughout the period, the risk attached to hnnd holdings was relatively low, so this figure cuuld be considered to have beell almost risk free. If it is adjusted upwards to allow for under-projection of the inflation rate, (for the reasons given above) the riskless discount rate for the U.S. economy in 1956-62 might have been put at three percent. Since PIES is in principle inflation-free, its considerably higher baseline ROR must be attributable to the implicit estimate of commercial risk in energy production. An alternative interpretation, however, is to suppose that PIES relates to an inflationary world with high borrowing rates, but that for convenience its price forecasts are expressed in relative terms, i.e., are, in effect, implicitly deflated of the inflation that is actually expected to occur. On this interpretation however, a borrowing rate of eight percent seems too low: with government-bond yields currently around seven percent, the margin for risk would seem inadequate. A11. these considerations are of considerable importance to the present inquiry, because they are relevant to the dimensions of the variations it is reasonable to expect in the rates of return that might be applied by divcsted companies vis-a-vis those of successor companies. As indicated in the text, we have decided that the theoretical and practical considerations we have adduced are sufficient to justify our treating the baseline ROR in PIES as if it were a "real" concept, and that consequently the variations possibly attributable to divestiture such as are investigated below are also to be regarded as variations of the "real" discount rate. 
The owner or leaser of a coal reserve, however, faces a series of technical problems which complicate the foregoing discussion. These revolve around the significance of the thicknesses of seams and associated underground distribution of seams according to thickness. In the case of a strip mine, once the workings have been opened it is impcssible, without encountering increasing costs, to take out coal at unlimited rates, if only for the reason that in order to get at the lower parts of the deposit, it is first necessary to remove the parts above. In a deep drift mine (where the underground seams are reached by driving a gently falling tunnel) where the drift has been constructed, it is impossible to gain access to more than a proportion of the available coal at any one time without either increasing operating costs or construction of another drift. Alternatively, where access is gained by vertical shafts, only a certain amount of coal can economically be produced from the seams opened up by a single shaft, so that more intensive exploitation requires either rising operating costs or the sinking of new shafts. In fact, there are safe limits to the numbers of shafts that llay be crowdod together, so that even this latter recourse is limited.

Martin B. Zimmerman has recently measured the cost conditions of coal production in the United States using much the same. sources of information used in creating the Coal Supply Model of 
PIES. ${ }^{7 /}$ He found that the increasing cost effect in relation to current output could be represented by an elasticity relationship in which total. costs of an output $q_{t}$ varied as $q_{t}{ }^{\infty}$ where $\propto$ is a number greater than one. Typically, for East Coast mining in the U.S., $\propto$ was estimated at about 1.3 . It follows that marginal costs vary with $q_{t}$ as $q_{t}(\propto-1)$ and if $K$ represents a constant element in costs, unit costs vary as $(\propto-1) q_{t}(\alpha-2)$ $-\mathrm{Kq}_{\mathrm{t}}{ }^{-2}$

The foregoing relationship applies to current operating costs. In addition, as a reserve is depleted, it is neccssary to work seams of decreasing thickness. Zimmerman calculated the effect of thickness variations on the level of costs at the minimum cost output and found that underground seam thick-

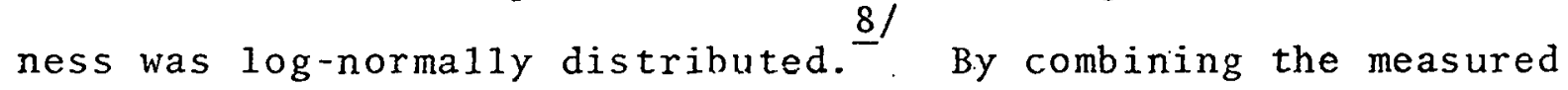
parameters of the cost function with those of the seam-distribution functiun he calculated the rates at which minimum-level unit operating costs would rise if current output rates were maintaincd for various periods of time. For example, if 1977 output rates are maintained into the future, the costs of producing low-sulphur South Appalachian coal are estimated to rise at 1.3 percent per

7/ Martin B. Zimmerman, "Modeliing Depletion in a Mineral Industry: The Case of Coal," Bell Journal of Economics, 1977 , and also by the same author, "Estimating a Policy Model of U.S. Coal Supply," MIT Energy Laboratory Working Paper, December 1977. PIES itse1f cannot bo nsed to ostimate corresponding functions because (a) it does not permit variation of output from operating mines, and. (b) it does not permit variations in depletion rates to affect 1985 supply curves.

8/. In shnrt, if the probability of tunding a seam of given thickness is measured on a regular vertical scale, while thickness itself is measured on a logarithmic horizontal scale, the resulting curve, based on the available geological information is a statist ${ }^{\circ}$ Norma1 Curve. 
annum. If output rates are increased, costs will.rise faster and vice versa. Zimmerman has estimated what is known as the cumulative cost function for coal, indicating the way that unit costs of current output vary, as well as varying with the current rate of output, according to the cumulative totai of past output.

A coal reserve holder, wishing to maximize the welfare of stockholders, would maximize the discounted present value of the future net revenues, using the highest discount rate available to stockholders on alternative uses of "their" money. In order to calculate coal supply for a given future year on the assumption that all reserve owners and mine operators were thus motivated, it is necessary to estimate the appropriate microeconomic optimal depletion paths of representative individual firms, and then to ascertain their explicit predictions for the year for which information is desired. In the present study it has been necessary to create such models in order to investigate how the predicted time paths of future supplies are affected by perturbations of variables that might be affected by divestiture. 'l'he results are presented in a later section.

Implications of "Synergy"

It has already been suggested that factors exist that create actual or potential advantages for oil firms operating in the coal industry. that would not be available to other busincs organizations and that might not be available to other business organizations and oil firms in alternative investment outlets. Such factors are referred to as synergistic effects 
when they are internal to the type of organization in question and not merely the result, for example, of the effects of reduced competition which might occur when corporations heavily involved in one branch of the energy buṣiness diversify into another branch. "Synergy" is an expression taken into economics from the biological sciences where it refers to the correlated actions of body organs, mental processes or remedial drugs: as a result of correlated action, the power of a system exceeds the sum of the powers of its part.s.

In thc cconomics of industrial organizaliun, a merger, for example, is said to have synergistic effects if the total profitearning power of the merged organization is greater (other than on account of monopolistic effects) than the sum of the previous profit-earning capacities of the constituent organizations.

In the present example, synergy refers to the possibility of technology transfer from the oil industry to the coal industry that might occur only via direct investment by large firms with long experience in the oil industry, and which might not be transferred by other means. When any corporation diversifies into another industry, it undertakes correlated actions involving management, administration, commercial practice and commercial and technological know-how or "information." It is not argued hore that oil companies curienly pussess appropriate techniques that only they have the legal right to employ in coal production.

9/ As a matter of fact, there is considerable evidence that genuinely synergistic mergers among large corporations are relatively rare. See Dennis Mueller, "Evidence on the Effects of Corporate Mergers," Journal of Banking \& Finance, 1977 , pp. $315-347$. 
Rather it is suggested that their total research and technological experience is of a character that makes them more likely to achieve future breakthroughs that might lead to major reductions in the cost of converting the energy in coal to usable energy at the home, cffice or factory. Underground gasification or liquefaction are examples of the types of possibilities suggested here. Many such ideas have been pursued, usually in times of extreme scarcity of oil supplies and have tended to be abandoned as oil became progressively cheaper. At the present time, with the high price of petroleum and a general concern for energy shortages, research on technologies of this type (in effect, technologies that treat coal like a refinery input) is more topical.

If such a potential technology is about to emerge, why cannot the actions of technology creation, technology transfer, and administrative/commercial organization be separated? The answer is that in large firms, the functions of technology management, development and planning; commercial management and planning; and finally the general administrative style are symbiotically linked. $10 /$ The "know-how" involved is a class of partly indivisible information. As such, it is not easily transferred from one place to another by market processes because, being difficult to define, it is not easily patented or appropriated. An organization possessing information of this kind can protect itself against providing benefits for free-riders only by doing the work itself.

$10 /$ See for example, T. Burns and G. Stalker, The Management of Innovation (2nd ed.) 1966. 
The transfer is effected by the accumulated experience of a team of people, a commodity which by its nature cannot easily be bought and sold.

The foregoing are the reasons for expecting the presence of synergistic effects. The argument that effects of this kind may exist is both logically powerful and supported elsewhere by empirical case studies. The difficulty in the present case is not so much the problem of asscssing whether, if relevant technology were to develop, it would be partly synergistic to oil majors, but rather whether this technology will in fact develop and what might be the plausible range of effect. Conceivably there could indeed be dramatic reductions in the cost of obtaining a calorie of usable energy from an underground coal deposit. Alternatively, owing to the inherent character of coal deposits (including the log-normal distribution of seams by thickness, referred to above), it might be that quite large changes in technology would have only relatively modest effects on either lahnr rosts or capital coets. For this reason, as will be seen below, we have preferred to approach the problem in our sensitivity analysis by setting rather narrow limits to the suggested range of plausible variation in labor costs and capital costs. If these produce significant results, it will be apparent that more dramatic changes of unknown dimensions would indeed have à culsiderable effect on the coal market. 


\section{CHAPTER $\quad 2-2$ \\ THE INVESTMENT AND GROWTH BEHAVIOR \\ OF SUCCESSOR COMPANIES \\ COMPARED TO DIVESTED COMPANIES}

As already argued, oil companies are large conglomerates possessing a considerable degree of economic discretion. The precise character of the successor companies is a matter of speculation, but it is reasonable to suppose that they would on average be less "managerial", than oil companies. (If this proposition is denied, apart from possible synergistic effects, this report need go no further, as divestiture can have no other effects.)

It is essential, therefore, in order to procede further, to consider the contribution of so-called "managerial" economic theories. 11/ These models are essentially due to William Baumol (1962), 0. E. Williamson (1964), R. Marris (1963, 1964), John Lintner (1971) and Robert Solow (1971). The 1972 models of Baumol and Williamson are not mainly concerned with investment; Lintner is mainly concerned with the relation between the growth of the firm and the behaviui of the stock market and the model of Solow is based on assumptions of monopolistic competition which, however useful in a more general context, are rather

11/ More precisely of theories of the output, pricing and gruwth of the firm which take account of a degree of autonomy of management. Typically such theories permit a degree of variation in assumed management motivation, e.g., Solow compares the effects of the criterion of stockholder-welfare maximization with those of the criterion of maximizing growth subject to a constraint. 
inappropriate to the coal industry. We therefore mainly employ the model of Marris, for the reasons given and also because it is associated with one of the authors of this report and therefore more readily adapted to the particular problem of coal.

Theories of the growth of the firm generally assume that the desires of management may be summarized under two headings, the desire to satisfy stockholders and the desire to pursue the growtl ur lhe organization. These two objectives are not necessarily complementary and may have to he traded off. Often, after a corporation has become mature, stockholders would benefit if it were wound up or at least ceased growing, but growth is usual1y pursued, nevertheless.12/. In other words, there is often a significant trade-off for management between the objectives of growth and of stockholder welfare; in the case of oil companies we must investigate the hypothesis that these companies will he more inclined to give weight. to the growth objective on average than will successor companies.

The Theory of the Growth of the Firm Applied to the Divestiture Problem

The "Marris" model can best be explained on the assumption that the growth of a firm is entirely internally financed. This assumption is not essential to the model but is useful when considering a problem where a possible surplus of internal finance is believed to be a major factor in the relcvant situation. $(197 \overline{2})$.

See Dennis Mueller "A Life Cycle Theory of the Firm" 
Marris assumes that the firm earns an exogenous operating profit from current operations which can be used either to finance the costs of growth or to distribute to stockholders. Both the current dividend and the expected growth of the firm and of its earnings are influential in determining the value of the firm on the stock market. The utility function of the manager has two arguments, stock market value and long-run growth rate of assets. A "classical" firm would choose a growth path to maximize stockmarket value. A more managerially-oriented firm would maximize the growth rate subject to a stock market minimum. This minimum stock market value is based on the fear of involuntary takeover. Its level is partly endogenous to the model but at the limit, it assumes a conservative valuation by a potential raider, i.e., a valuation presuming that the taken-over assets would be operated as a portfolio investment. The potential raider is presumed to value the firm as if he would not be able to organize any further growth of the taken-over business. In choosing the price of tender offer, a raider would maximize his minimum outcome by calculating the effects of merely continuing current operations in already established markets, and would not in this calculation take credit for any improvements that he may be able to effect in the organization. The raider is presumed to value the firm as it womld he valued by the stock market if the existing management decides to announce that planned future growth has been reduced to zero. If the existing management had previously been behaving "managerially", some reduction of the 
expected growth rate would raise the stock market value; but a reduction to zero with corresponding increased dividends would be excessive and might reduce the stock market value. The limit valuation is therefore lower than a valuation that might be put on the firm by a more optimistic raider, and is intended to reflect an outer boundary of "managerial" behavior. Marris also makes provisions (in a motivational variable, signified hy $M$, see below) for existing management to consider the likelihood that the danger of takeover is in reality more potent.

As the firm grows, it can suslain a constant level of operat-. ing profit on capital employed, provided it devotes sufficient resources to research and development. The costs of these activities represent a burden on distributable earnings. By making appropriate assumptions concerning the behavior of these costs as well as assumptions about the artual stock market valuation function, it is possible to find the optimum growth fale for a given utility function.

Marris used the following variables:

$\hat{\mathrm{p}}$. The current "operating" profit rate of the individual firm-profits reported if no resources were devoted to growth, i.e., if no money was spent on rcsearcl devleopment or on the administration or planning of growth;

d Total current dividend normalized by book value of assets;

$v$ Valuation ratio (normalized stock market. value--total issucd shares multiplied by stock market equity share price, divided by book value of assets);

$b_{1}$ Price-dividend ratio if the firm were not expected to grow, i.e., the price at which the stock market would value the shares if the expected value of future dividends were equal to the actual value of the current dividend; 
$b_{2}$ The amount by which $b_{1}$ will be increased (if, in fact, some growth is expected) for each unit of the proportionate growth ratio;

b. $b_{1} / b_{2}$ in effect a measure of the stock market's preference for current as against future dividends, taking account of pure time discount, risk-aversion and of expectations concerning the development of risk through time; (see Lintner (1964 and 1971));

$\lambda$ Coefficient of the "cost of growth"; the amount of money (normalized by book value of assets) which must be diverted from operating profits to support one point of sustainable proportional growth; in other words, a measure of the "unit cost" of growth-supporting activities such as search, research, development and planning; (Penrose, 1959; Marris, 1964, Ch. 3);

$M \quad$ Motivational indicator bounded by $M=\frac{1}{2}$ and $M=1$; in the former case the firm is maximizing the valuation ratio ("classic" or "stockholder" motivation); in the latter it is maximizing its own growth rate, $g$, subject to the constraint that the valuation ratio not fal. 1 below the limit value as defined above.

With the above variables, the basic equations of the Marris model are:

$$
\begin{aligned}
& \mathrm{d}=\hat{\mathrm{p}}-\lambda \mathrm{g}-\mathrm{g} \\
& \mathrm{v}=\mathrm{d} \cdot\left(\mathrm{b}_{1}+\mathrm{b}_{2} \mathrm{~g}\right)
\end{aligned}
$$

The first equation is an identity that follows from the assumption of internal financing and the second represents the stock market assumptions described above in the definitions of $b_{1}$ and $b_{2}$. The firm is valued first on the basis of its current dividend, $d$, and then a further amount is added to this valuation to take account of the expected growth rate, g. In Marris's model and in other similar models such as those of Lintner (1971) and Solow (1971), the firm grows in steady state. Given the appropriate growth-supporting expenditure as indicated by the 
coefficient, $\lambda$, the firm can grow at the indicated rate, $g$, while sustaining a constant operating profit rate, $\hat{p}$, whose (time-wise constant) level is treated as the exogenous result of the competitive or oligopolistic commercial conditions in its existing markets. Since the firm is growing with internal finance at a steady rate, the growth rate of dividends will be equal to the growth rale of earnings which in turn will be equal to the general growth rate, $g$.

It can be shown that in order to llaximize the valuation ratio (which would be appropriate for a firm with no "managerial" motivation), we would find the growth rate that satisfied the equation,

$$
g=\frac{1}{2}(\hat{p} /(1+\lambda)-b)
$$

To maximize growth subject to the indicated constraint (see above), the optimum growth rate is precisely twice this rate. (The first result is obtained by combining (1) and (2), solving for $v$, and differentrating $v$ with respect to $g$. The second result is obtained by solving $v$ for $g=0$ and substituting this value to find the corresponding value for g.)

Hence the general solution is,

$$
g^{*}=M \cdot\left(\hat{p} /(1+\lambda)-\text { b) } \frac{1}{2}=M=1\right.
$$

where $g^{*}$ is the utility-maximizing growth rale for a firm whose motivational indicator (measuring degree of "managerial" motivation) is $M$.

Since the reported profit rate, defined as $p^{*}=\hat{p}-\lambda g^{*}$ is endogenous, i.e., to be determined in the system, equation (4) 
can be estimated by regressing $g^{*}$ on $\mathrm{p}^{*} . \underline{13 /}$ The coefficient of the cost of growth, $\lambda$, is constant with respect to time and $g$. Several important conslusions follow:

(a) The theory predicts that if $M$ is independent of $\hat{p}$. firms are optimizing according to the model; from equation (4), growth rates will be positively correlated with operating profit rates;

(b) Estimation of (4) in several empirical tests have been made and they show that, typically, there exists a positive relationship between growth rates and reported profit rates. $14 /$

(c) If $M$ is independent of $\hat{p}$, reported profit rates will be negatively associated with the degree of "manageria1ism."15/

$$
\begin{aligned}
& \text { 13/ } g^{*}=M \cdot\left\{\frac{\hat{p}}{(\overline{1+\lambda})}-\vec{b}\right\} \text { and } \hat{p}=p^{*}+\lambda g^{*} \text {. } \\
& g^{*}=M \cdot\left\{\frac{p^{*}+\lambda g^{*}}{1+\lambda},-b\right\} \\
& \mathrm{g}^{*}=\left(\frac{\mathrm{M}}{1+-\mathrm{M} \lambda}\right) \mathrm{p}^{*}\left\{\frac{1+\lambda) \mathrm{M}}{1+\lambda-M}\right\} \mathrm{b}
\end{aligned}
$$

14/ This is confirmed in rather robust observations over a number of industries, time periods, and countries (Eatwe11, 1971, and Marris, 1971).

15/. From $\mathrm{p}^{*}=\hat{\mathrm{p}}-\lambda \mathrm{g}^{*}$, substitute equation (4)

$$
\begin{aligned}
p^{*} & =\hat{p}-\lambda\left\{M \cdot\left(\frac{\hat{p}}{(1+\lambda)}-b\right)\right\} \\
& =\hat{p} \frac{(1+\lambda)(1-M)}{1+\lambda}+\lambda M b
\end{aligned}
$$

where $b^{\simeq} 0 \cdot p^{*}=\hat{p} \cdot \frac{(1+\lambda)(1-M)}{1+\lambda}$

(Continued on nexi page) 
The Marris model predicts that, other things being equal, a firm with a more managerial motivation will grow faster for a given operating profit rate and will display a lower reported profit rate.

The reported profit rate in the model is averaged over all the firm's operations. In the case of an oil firm with coal interests, the firm would average oil, coal and other operations. There is some evidence that large corporations employ cutoff rates of return that are implicitly derived from the kinds of considerations at work in a model. The target rate of return reflects scarcity of capital within the firm, given the anticipated overall growth rate. Oil companies are worldwide conglomerates with a strong technological/managerial ethos. It could be argued that they are likely to adhere to more "managerial" utility functions than successor companies and that therefore their target rates of return will also generaliy tend to be lower. If they have cash available, they will tend to employ it internally rather than distribute it.

The Marris-Mueller mode1s relate to firms in general and do not specify the industrial direction of growth, but Marris in particular emphasizes that firms first tend to enter those (Continued)

15. If the degree of owner-control in stock=llarket holding structure is taken as a (negative) proxy for managerialism, this also is confirmed in empirical studies (Monsen, Radice), but the same studies tend to negate the positive association between managerialism and growth indicated by Equation (4). There is often positive correlation between owner control and operating profitability. In the present case (of oil divestiture from coal), it is unlikely that "management-controlled" oil companies would display systematically lower operating efficiency than ownercontrolled successor companies. 
fields where they have some managerial comparative advantage or other potential synergy. Oil companies believe they have such an advantage in the coal industry. This would be reflected in lower estimates of the coefficient, $\lambda$.

$A^{\prime}$ factor: working in the opposite direction would be any tendency (as will be further discussed below) for oil companies to reduce the competitiveness of the pricing process in the industry. This would be reflected, in the managerial model, in a higher rate of operating profit leading in turn to a higher target return, and a general upward shift of the industry supply curve.

To sum up, the theory implies that divested oil companies would wish to grow faster and accept lower reported profit rates for given operating profit rates than would successor companies.

\section{Optimal Depletion Theory}

The classic theorem for this problem is due to Harold Hotelling (1931). Firms in an industry that has a cumulative cost function anticipate that, because costs will rise as production cumulates, future price must also be expected to rise. In equilibrium the actual growth rate of the price must be equal to the anticipated rate. Thus the "price-taking". firm is faced with an expected future path of the price and must decide annual and total future production. The path must be consistent with no firm having an incentive to hold back output in any year in order to take advantage of the future increase in the value of unextracted reserves. This 
condition will be satisfied if the expected price path is such that the proportional growth rate of operating profits (net of deferred investment) per unit of output attributable to rising future prices is precisely equal to the market rate of interest. If profitability is rising proportionately faster than the rate of interest, it will pay to "hoard" the reserve; if it is rising less fast it wịll pay to dump as much as possible on the market so that the profits so earned may be reinvested more profitably at the market interest rate. The resulting theorem (known as Hotelling's theorem) is often expressed in terms of the net price $16 /$ (gross price less extraction costs including deferred investment), but is more easily understood in terms of gross price. If gross price increases by an amount dp, the associated proportional increase in profit per unit of output with given unit costs, $\underline{\text { c }}$ is $d p /(p-c)$. This must grow per unit of time, dt, at the rate of interest $r$. Hence we have,

$$
d p / d t=r \cdot(p-c)
$$

It is simple to show that the net price, say p' (defined as $\mathrm{p}-\mathrm{h}$ ) and the rate of interest have the following relationship when $c$ itself is increasing through time (as a result of cumulative output):

$$
r=q / p^{\prime} \cdot d c / d Q+d p^{\prime} / p^{\prime}: 1 / d t
$$

where $q$ signifies current output and $Q$ cumulative output.

16!'See, e.g., Herfindah1 and Kneese, Economic Theory of Natural Resources, 1974, p. 126. 
If a path meeting the above conditions is followed, the discounted present value of the reserve will be maximized. A path of this type cannot be solved without knowing the equilibrium conditions for the whole industry, including the demand curve. Via the demand curve, the price path determines the output path and hence the cost path which in turn reacts on the price path, and so on. In addition, the precise form of the cumulative cost functions must be known $17 /$

There are few examples of specific solutions to paths of this kind. An alternative, simpler approach is to assume that the industry is myopic and that each firm determines an output path on the assumption that current prices will rule indefinitely into the future. This approach is more consistent with the methodology of PIES though perhaps somewhat unrealistic in light of recent rates of increase in coal prices. However, it i.s satisfactory for illustrating qualitative effects and is also effective in assessing the quantitative impact of more important perturbations of relevant variables such as the rate of discount.

The "simple.r" problem may be described by the following equations:

$$
\begin{aligned}
& \pi t=P q_{t}-c_{t} . \\
& c_{t}=C\left(q_{t}, \sum_{0}^{t} q_{t}\right)
\end{aligned}
$$

17 Unless all its higher derivatives are zero, the coefficient dc/dQ. "will not, of course, be constant and may well be endogenous to the problem in a complex way. 


$$
\begin{aligned}
& \mathrm{D}=\sum_{0}^{\infty} \pi_{t} \mathrm{e}^{-r t}-K_{0} \\
& \mathrm{q}_{t}=F(t)
\end{aligned}
$$

where,

$$
\begin{aligned}
& q_{t}=\text { quantity produced at time } t \text {, } \\
& \begin{aligned}
\pi_{t}= & \text { net cash flow from producing and } \\
& \text { selling } q_{t} \text { at price } P \text {, }
\end{aligned} \\
& \begin{aligned}
& C_{t}= \text { total costs of producing } q_{1}, \\
& \text { including deferred inve } 3 \text { tment }
\end{aligned} \\
& \text { D = discounted present. vạlue, } \\
& r=\text { rate of discount, } \\
& K_{0}=\text { initial investment. }
\end{aligned}
$$

The problem is to find the function; $F(t)$, that maximizes, $D$, subject to (1) and (2). $K_{0}$, initial investment, may also be considered endogenous; for example, it could be a function of $q_{0}$, of $1 / t \sum_{0}^{\infty} q_{t}$ or of $q_{j}$ where $q_{j}$ is the peak value of $q_{t}$ in lhe optimum path.

The models below use the second assumption. We also employ the specific cost-function based on PIES data estimated by Ziinterman às already described above. Consequently, the complete model involves two further equations, namely

$$
\begin{aligned}
& r_{t}=a_{t}^{\alpha \cdot q_{t}^{\alpha}}\left(\sum q_{t}\right)^{\beta}-c \\
& K_{0}=k_{t: 0}^{T} q_{t}
\end{aligned}
$$

where $\alpha$ and $B$ are elasticities, $C$ is a constant element in operating costs, $\underline{a}$ is a general-cost parameter, $k$ is a 
capital/output parameter, and $\mathrm{T}$ is the economic life of the reserve; i.e., the period over which there is profitable production, (an endogenous variable - see below).

As in the Hotelling theorem, there are general theorems relating to the appropriate optimal paths for this problem, but no specific results $\frac{1 \mathcal{E} /}{-}$ By means of simulation, using parameters consistent with PIES, we investigated four types of constrained paths, namely:

$$
\text { (i) } \begin{aligned}
q_{t} & =q_{0}(1-x t) \\
\text { (ii) } q_{t} & =q_{0}-\varepsilon t \\
\text { (iii) } q_{t} & =q_{0} E^{-\delta t} \\
\text { (iv) } q_{t} & =q_{0} \text { for } t \leq T \\
q_{t} & =0 \text { for } t>T
\end{aligned}
$$

where $T$. is defined in years so that all $\pi_{t}(t \leq T)$ are positive and all $\pi_{t}(t>T)$ are strictly negative.

Experiments were made to find maximum values of $D$ by varying $q_{n}$ and $\tau$ in (i), $q_{0}$ and $\varepsilon$ in (ii), $q_{0}$ and $\delta$ in (iii), and $q_{0}$ and $T$ in ( $i v$ ).

Paths of type (iv) dominated all others. Since optimal paths in this type of model display declining output (Herfindahl and Kneese p. 119), this result must indicate that none of the paths are strictly optimal: calculation of actual optimal paths was too complex. It seems that rectangular paths (type (iv)),

18f Herfindah 1 and Kneese, op. cit. 
with a variable depletion period, T, provide good approximations for our purpose, and are especially consistent with the methodology of PIES.

Before displaying the results of the simulations, the following theoretical predictions may be enumerated:

(i) A decrease in $\tau$ will reduce $q_{0}$ and increase $T$; less coal is produced now, but economic life is extended;

(ii) A decrease in a, (the general coefficient of operating costs and defcrrcd investment) will increase $q_{0}$ and $T$, i.e., as in the case of a downward shitt of a conventional supply curve, more is produced at a given price both now and in the future;

(iii) A decrease in $k$ will have similar effects to a decrease in a.

The model was simulated with baseline values consistent with PIES, including $\tau$ at $8 \%$, and then appropriately perturbed to investigate effects on optimal paths.

The specific baseline parameter values were $a=5.162\left(10^{-2}\right)$, $\mathrm{C}=30, \mathrm{k}=1, \mathrm{P}=1, \alpha=1.3$ and $\beta=.15$ (the latter two figures being derived from Zimmerman 1977, second citation). With price normalized at unity, quantity units are arbitrary. The dimensional realism of the model may be verified by expressing $D$ for each optimum path as a percentage of the corresponding calculated figure of the discounted present value of gross sales. This is a "timeless" representation of the ratio of profits to sales, when all capital costs, including implicit amortization and interest on initial capital, as well as deferred capital costs, 
have been deducted from profit. In other words, this calculation represents the margin of "pure" profit, and should be fairly small, e.g. from 0 to $15 \%$ (as will be seen, in the baseline it was $5.9 \%$ - any mine offering a positive margin will be worked unless the return is so small as to be not worth the managerial effort). In the table below, the figure, expressed as a percentage, is termed "margin." The results are given in Table II-2 below.

From the table, the folloving is clear:

(a) The effects of strong $r$-variations are quite modest;

(b) The effects of cost-of-capital and general-cost variations are strong, e.g., a five percent variation in the coefficient produces a ten percent variation in output.

The foregoing conclusions do not exhaust the list of possible economic effects of variations in rate of discount or return. The depletion model does not deal with the effect of variations of $\tau$ on the number of actual or potential mines displaying positive discounted present value. The more general "managerial" effect as against the pure depletion effect - of more abundant capital supplies in oil-owned coal enterprises must be investigated directly in. PIES. By contrast, PIES at present cannot handie the depletion effect. But having now ascertained from simulations using data consistent with PIES that the depletion effect seems likely to be small (and in using data for South Appalachian low-sulphur coal with lagged results in favor of a strong effect; for high-sulphur çoals for all North Appalachian and Western coals the effect would be further weakened), we make no further 
TABLE I.I-2

Optimal Outputs, Economic Lives,

Discounted Present Values and Discounted

Profit Margins Derived from Depletion-Mode1

$\underline{\text { Simulations }}$

\begin{tabular}{|c|c|c|c|c|c|}
\hline \multirow{2}{*}{\multicolumn{2}{|c|}{ Baseline }} & $q_{0}^{*}$ & $T^{* *}$ & $\mathrm{DPV}^{*}$ & Margin \\
\hline & & 100 & 28 & 100 & $5.9 \%$ \\
\hline \multicolumn{6}{|c|}{ Perturbations: } \\
\hline$\underline{a}$ down & $5 \%$ & 110 & 36 & 159 & $8.1 \%$ \\
\hline$\underline{\mathrm{k}} "$ & $"$ & 111 & 35 & 167 & $8.5 \%$ \\
\hline$\underline{\mathbf{r}}$ down & 5 points & 97 & 29 & 177 & 6.3 \\
\hline$" 1 "$ & $3 \quad$ & 99 & $28 \frac{1}{2}$ & 141 & 6.4 \\
\hline " up & $"$ & 102 & 27 & 54 & 4.6 \\
\hline & & $\begin{array}{l}{ }_{*}^{*} \mathrm{~B} \text { as } \\
* *\end{array}$ & $\begin{array}{l}\text { ine } \\
\text { is. }\end{array}$ & 100 & \\
\hline
\end{tabular}


attempt to introduce a depletion effect directly into PIES.

\section{Competitive Effects}

Clearly, a major factor will be introduced if the presence of oil companies, as opposed to successor companies, reduces the competitiveness of the coal industry's pricing practices.

From the large literature of industrial organization, there has emerged a degree of consensus that the competitiveness of an industry's price structure (as measured by margins or sustainable rates of return) will depend in combination on its internal structure and behavior (oligopolistic or competitive as the case may be) and on the extent to which barriers to entry (or their absence) prevent outside firms from coming in to drive out the effects of less-than-competitive internal practices. In turn it has been usual to attempt to measure the propensity to "internal" oligopoly by the proxy of conventional concentration ratios, and the barriers to entry by direct investigation of such factors for entry and so on.

The role of combination among these two groups of factors is essential to a proper understanding of the problem. In the absence of concentration, competition may be quite intensive even in the absence of barriers to entry. Conversely, no amount of internal oligopolistic behavior can easily sustain high profits in the presence of a permanent and vigorous entry threat.

A considerable literature, stemming from the pioneering work of Joe S. Bain (1956), has attempted to measure the strength of these factors, and to relate them to observed profitability rates; in U.S. industry. For the present purpose, however, it 
is also necessary to take account of the theory of the growth of the firm. We have seen that this theory predicts that the reported profit rates of individual firms will tend to be positively associated with their growth rates. This proposition essentially relates to the population of individual firms as a whole, and has been tested on large, multi-industry samples. Nevertheless, there will tend to be common factors operating within individual industrias on the coefficients of the yruwll. model with respect to individual firms. In short, some industries wi11 grow faster than others. Some part of the inter-industry variances of reported profit rates must be due to inter-industry variances of the factors affecting firm growth rates.. It is necessary, therefore to eliminate this factor from econometric models designed to explain inter-industry profit rates. Otherwise, models will be misspecified and there is danger uf the introduction of a bias into the estimates of the effect on industry profil rates of concentration ratios or barriers to entry. This is confirmed by studies which show that introduction of the industry growth rate as an explanatory variable does, in fact, change both the estimated values of the relevant coefficients as well as reduce their statistical significance.

The most comprehensive study was that of K. D. George. This takes into account the theoretical considerations that concentration and barriers to entry will most likely "work" in combination, but not independently, plus the effects of interindustry growth rate variations. Using four-firm concentration

19/ K. D. George (1968). 
ratios for 28 U.S. manufacturing industries and Mann's classification of industries with respect to direct barriers (based originally on Bain) he obtained the following equation:

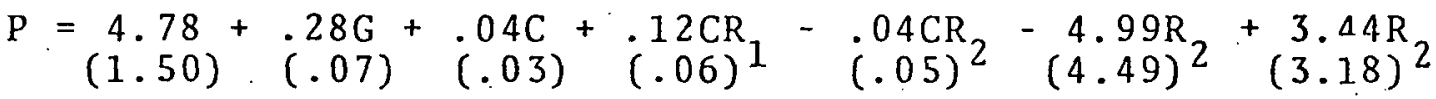

$$
\begin{aligned}
& \mathrm{R}^{2}=.79
\end{aligned}
$$

The key conclusion of this equation is that neither barriers to entry nor concentration acting alone has a s.tatistically significant effect on the profit rate of an industry with a given average growth rate. By contrast, the combination variable, $\mathrm{CR}_{1}$ has a substantial effect. In an industry with "Very High" barriers to entry, every ten percentage points of positive variation in the four-firm concentration ratio caused a 1.2 percent increase in the industry profit rate.

Many writers have addressed the question of entry barriers and general competitiveness in the coal industry. Leonard and Schmookler have each, in different editions of The Structure of American Industry, addressed the question of the competitiveness of the coal industry. Leonard cites the existence of 6000 sellers in 1946, none of which controlled $3 \%$ of total industry output, plus the fact that the industry has no price leader as evidence of competitiveness within the industry. In addition, he also cites the absence of patent restrictions and the inability to differentiate products as further evidence of the existence of competition. 20.

$20 /$ Norman H. Leonard, "The Rituminous Coal Industry," in The Structure of American Industry, ed. by Walter Adams (New York: The Macmilian Co., 1950), pp. 34-35. 
Jacob Schmookler, in a revised edition of The Structure of American Industry, draws a different conclusion. $\underline{21}$ on the selling. side he notes the existence of product differences, negatively sloped individual demand curves, selling expenses, locational advantages, price discrimination practices, and individual consumer preferences - all of which lead to imperfectly competitive markets.

Reed Moyer's Competition in the Midwestern Coal Industry demonstrates that the midwestern coal market can be accurately labcled as an "olignpoly with a competitive fringe." He shows that freight rate barriers effectively isolate the Midwestern

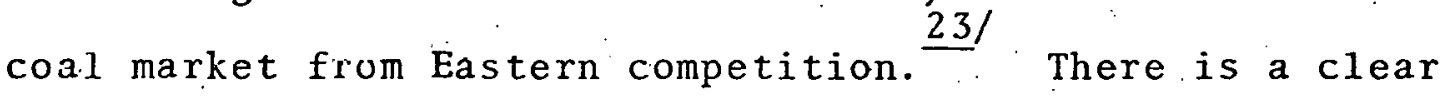
trend Luward concentration and numerous barriers to entry. The most desirable reserves are controlled by the largest producers and much of the coal supply is committed to utility companics through long-term contracts. Many smaller firms cannot secure these contracts due to 1 ack of reserves. In addition, freight rate structures have been altered so that large shippers can receive quantity discounts that may be difficult for smaller companies to secure. $24 /$ Mnyer aleo demonstrates that in the presence of concentration and barriers to entry, prices have

21./ Jacob Schmookier, "The Bituminous Coal Industry," in The Struclure of American Industry, ed. by Walter Adams, Revised ed. (New York: The Macmillan Company, 1954), p. 79.

22/ Reed Moyer, Competition in the Midwestern Coal Industry. (Cambridge: Harvard University Press, 1964).

23/ Ibid., p. 21 .

24/ Ibid., p. 138 . 
been more stable and profits higher in the Midwestern coal industry than in the East. $25 /$

Though competition may still be intense in some regions, conditions in the Midwestern industry, which Moyer has shown to. be much more oligopolistic in nature, show that broad statements concerning the coal industry and its competitiveness must be regarded with suspicion.

With the climb in the world price of energy since 1970, and the ensuing rise in the profitability of the coal industry, a degree of new entry was to be expected in which oil companies played a vigorous role. There are two reasons, however, why. we cannot presume that oil companies reduce the competitiveness of the industry. First, concentration did not increase. Second, oil companies did not alter technical or other conditions, such as the height of entry barriers.

At issue is whether the technology of oil companies might, in the future, bring into the coal industry an increase in entry barriers by reducing operating costs while requiring a relatively larger initial investment. This argument is two-edged because if it is desirable that such technology be developed, the effect on entry barriers is a social necessity. Furthermore, there is a question as to whether the presumption by entry-deterrent theory that the presence of large firms increases barriers to entry (and, by implication, the entry of large conglomerates into an industry would reduce competition) is logically sound or empiri- ' cally justified. Large comglomerates possess precisely the

25/. Thid, p. 171 
financial strength that is needed to overcome financial entry barriers. Hence, the entry of oil companies could have increased coal industry competitiveness. Finally, although we have been supposing that successor companies will differ significantly from oil companies in managerial motivation, it is not at all apparent that such companies would have markedly different competitive effects on the coal industry than oil companies.

For the above reasons, a good case can be made for attributing no "monopolistic" or "anti-monopolistic" effect to divestiture. However, there may be individuals who are unable to accept this conclusion on the basis of the above arguments. The fear of long-term,reductions in competitiveness is a major political factor engendering demands for divestiture legislation. For the benefit of those who believe that divestiture shall cause pro-competitive effects we thérefore undertake some appropriate perturhatinns.

\section{Conclusions}

The important conclusions of this chapter with respect to the economic effects of divestiture may be summarized as follows:

(a) The possible effects revolve around possible differenres in behavior and/or performance hetween firms which would be prevented from staying in or in the future entering the coal industry (namely, oil firms) and hypothetical "successor" firms, the latter meaning either firms who would replace the output of divested firms or firms who would replace the contribution to future output of oil firms who would otherwise have been permitted future entry. 
(b) Such differences in behavior or performance cannot occur unless circumstances permit coal operators a significant degree of economic discretion and unless oil firms who are coal operators wish to exercise such discretion to implement different policies from the policies that could be pursued by successor companies.

(c) In its traditional form the neo-classical theory of the firm, in both its competitive and its imperfectly competitive versions, hasn't much to contribute to the question, because both versions assume conditions that deny discretion and also axiomatically assume that whoever or whatever controls a business must adopt the unique criterion of profit maximization through time. The coal subsidiary of an oil company should pursue this criterion in the same way as any successor company irrespective of significant differences in the costs of capital, management orientation, etc., of the parent company.

(d) With adaptations, however, the neo-classical theory can in fact make useful contributions to the divestiture problem, in particular the idea that the market value of stockholders' equity can be a major argument of firms' objective functions may be accepted. It is recognized that what is relevant is the difference if any between attitudes to stockholder welfare of the management of oil companies on the one hand and the corresponding attitudes among successor companies on the other. 
(e) The possibility that important new techniques might be introduced into the coal industry through the medium of direct investment by oil companies in their coal subsidiaries-techniques which would be lost to both the coal industry and to society in the event of divestiture-depends on the possible appearance of "synergistic" effects, indivisible packages of administrative, commercial and technological inputs which heing more powerful in combination than in aggregation, cannot be transferred by regular market processes; the conclusion is that the pussibility of such effects between the oil and coal industries must be taken seriously; although it is not easy to estimate their likely quantitative importance .

(f) "Managerial" or "discretionary" theories of the firm, al though originally developed lo deal with firms in economic circumstances rather different from those of the coal industry (although rather similar to those of oil conglomerates), may be adaptable to deal with those aspects of the basic questions at issuc.

(g) Coal being a depletable natural resuurce, the economic theory of optimal depletion, originally developed in a neo-classical framework, may be joined to the combination of neo-classical with managerial theory discussed above, to investigate the quantitative significance of the claim that divestiturc might lead to more rapid depletion 
of coal reserves; however, a simulation of optimal paths, based on data consistent with PIES, has suggested that the effects of divestiture on the coal industry's overal1 depletion rate in 1985 will in fact be likely to be small.

(h) In the present state of empirical understanding of the theory of the firm in relation to large corporations, it is impossible to offer rigid quantitative predictions in answer to the questions originally purposed. It is necessary, therefore, to employ sensitivity analysis co determine the plausible range of quantitative effects; the PIFS model, together with a specially developed simulation model concerned.with the depletion problem, are perturbed by amounts within a plausible range in order to determine the validity and quantitative significance of each effect. 


\section{BIBLIOGRAPHY}

1. Arrow, Kenneth. "The Firm in General Equilibrium Theory." The Corporate Economy. Edited by R. Marris and A. Wood. Cambridge: Harvard University Press, 1971.

2. "The Agenda of Organizations." The corponate Society. Edited by R. Marris. New York: Wiley, 1974.

3. and Hahn, Frank. General Competitive Analysis. San Francisco: Holden-Day, 1971 .

4. Aumann, Robert J., ed. Advanses in Game Theory: Princeton: Princeton University Press, 1964.

5. Bain, Joe S. Barriers to New Competition. Cambridge: Harvard University Press, 1956.

6. Industrial Organisation. New York: John Wiley \& Sons, 1968.

7. Baumol, W.J. Business Behavior Values and Growth. New York: The Macmillan Co.. 1959.

8. "On the Behavioral Theory of the Firm." The Corporate Economy. Edited by R. Marris and A. Wood. Cambridge: Harvard University Press, $19 \% 1$.

9. Boulding, Kenneth E. "Implications for General Economics of Mnre kealistic Theorica of the Firin." Anerican biconomic Review. (May, 1952), 35-45.

10. Bower, Joseph L. "Planning Within the Firm." American Economic Review (May, 1970), 186-194.

11. Burns, T. and Stalker, G. The Management of Innovation. 2 nd ed. London: Tavistock Publications, 1966.

12. Coase, R.M. "The Nature of the Firm." Economica (November 1937), $386=405$.

13. Cyert, R. and Cohen, R. Theory of the Firm. Englewood cliffs, N.J.: Prentice-Hall, 1965.

14. and March, J. A Behavioral Theory of the Firm. Englewood. Cliffs, N.J.: Prentice-Hall, 1963. 
15. Eatwell, John. "Growth, Profitability and Size." The Corporate Economy. Appendix A. Edited by R. Marris and A. Wood. Cambridge: Harvard University Press, 1971.

16. Gale, B. "Market Share and Rate of Return." Review of Economics and Statistics, 54 (November, 1972), 412-423.

17. Gaskins, Darius. "Dynamic Limit Pricing: Optimal Pricing Under Threat of Entry." Journal of Economic Theory (September, 1971), 306-22.

18. George, K. "Concentration, Barriers to Entry, and Rates of Return." Review of Economics and Statistics, 50 (May, 1968), 272-275.

19. Hall, M. and Weiss, L. "Firm Size and Profitability." Review of Economics and Statistics; 49 (August, 1967), 319-331.

20. Harsanyi, J. "A General Theory of Rational Behavior in Game situations." Econometrica. (1966).

21. Rational Behavior and Bargaining Equilibrium in Games and Social Situations. Cambridge: Cambridge University Press, 1977.

22. Heflebower, Richard. "Observations on Decentralization in Large Enterprises." Journal of Industrial Economics (November, 1960), 7-22.

23. Herfindahl, Orris C. and Kneese, Allen V. Economic Theory of Natural Resources. Columbus, Ohio: Merrill, 1974.

24. Leonard, Norman $\mathrm{H}$. "The Bituminous Coal Industry:" The Structure of American Industry. Edited by Walter Adams. New York: The Macmillan Co.. 1950.

25. Lintner, John." "Optimal Dividends and Corporate Growth Under Uncertainty:" Quarterly Journal of Economics (February, 1964)

26. "Optimum or Maximum Corporate Growth Under Uncertainty." The Corporate Economy. Edited by R. Marris and A. Wood. Cambridge: Harvard University Press, 1971.

27. Luce, Robert D. and Raiffa, Howard. Games and Decisions, New York: Wiley, 1957. 
28. Mann, M. "Seller Concentration, Barriers to Entry, and Rates of Return in 30 Industries, 1950-1960. Review of Econnmics and Statistics, 48 (August, 1966), 296-307.

29. Margolis, Julius. "The Analysis of the Firm: Rationalism, Conventionalism, and Behavioxism." Journal of Business (July, 1958). 187-199.

30. Marris, R.L, "A llodel of the Managerial Enterprise." Quarterly Journal of Economics (1963).

31. - The Economic Theory of "Managerial" Capitalism- New York: Basic Books, Inc., 1964.

32. "Why, Economics Needs a Theory of the Firm." Economic Journal Supplement (May, 1972), pp. 321-52.

33. - "An Introduction to Theorles of Corporate Growth." Tle Corporate Economy. Edited by R. Marris and A. Wood. Cambriage: IIarvara-University Press, 1971.

34. - "The Modern Corporation in Economic Theory:" The Corporate Economy. Editcd $\mathrm{by} K$. Marris and $\mathrm{A}$. Wood. Cambridge: Harvard University Press. 1971.

35. and yood, A., eds. The Corporate Economy. Cambriage= Harvard University press, 1971.

36. Marshall, Alfred. Principlc3 of Economics. 2nd Erition. Londor Mäcmillan Co.. 1891.

37. Menzies, Hugh D.. "Why Sun is Educating Itself out of oil." Forturie (F'ebruary. 27, 1978), 42-47.

38. Miller, R. "Marginal Concentration Ratios and Industrial profit Rates." Southern Economie Journal, 34 (October, 1967), 259-267.

39. Modigliani, Franco. "New Developments on the oligopoly Front." Jouxnal of Political Economy (June, 1958), 215-232.

4.0. Monsen, R.J. and Downes, Anthuny. "A iheory of Iarge Managerial ririns.". Journal of Political Economy (June, 1965), 221-236. 
41. Moyer, Reed. Competition in the Midwestern coal Industry-

Cambridge: Harvard University Press, 1964.

42. Muellex, Dennis. "A Theory of Conglomerate Mergers." Quarterly Journal of Economics, (1969).

43.

"A Life-Cycle Theory of the Firm." Journal of Industrial Economics (1972).

44. - "Evidence on the Effects of Corporate Mergers." Journal of Banking and Finance (1977).

45. and Grabowski, Henry. "Managerial and StockholderWelfare Models of Firm Expenditures." Review of Economics and Statistics (1972).

46. Ornstein, S. "Concentration and profits." The Impact of Larqe Firms on the U.S. Economy. Edited by. Weston and Ornstein.. Lexington Books, 1973.

47. Penrose, Edith. The Theory of the Growth of the Firm. Oxford: Blackwell, 1959 .

48. Robinson, E.A.G. The structure of Competitive Industry- Cambridge: Cambridge University Press, 1958.

49. Schmookler, Jacob. "The Bituminous Coal Industry." The Structure of American Industry.: Revised edition. Edited by Walter Adams. New York: The Macmillan Co.. 1954.

50. Shubik, Martin, ed. Essays in Mathematical Economics in Honor of Oskar Morqenstern. Princeton, N.J.: Princegen University Press, 1967.

51. 1 strategy and Market structure = Competition oligopoly and the Theory of Games. New York: Wiley. 1959.

52. Simon, Herbert. "New Developments in the Theory of the Firm." American Economic Review (1962).

53. Solow, Robert. "Some Impiications of Alternative Criteria for the Firm." The Corporate Economy- Edited by R. Marris and A. Wood. Cambridge: Harvard University Press, 1971.

54. Stigler, G. Capital and Rates of Return in Manufacturing Industries. Princeton: Princeton University Press, 1963. 
55. Sylos-tabini, Paolo. oliqopoly and Technical proqress. Rel Edition. Cambridge: Iarvard University Press, 1969.

56. Uttal, Bxo. "Exxon has its Eye on More than Oil." Foxtune (April, 1977), 166-168.

57. Weiss, Leonard W. "The Concentration - Profits Relationship and Antitrust." Industrial concentration: The New Learning. Edited by H. Goldschmid, H. Mann, and J. Weston. Boston: Little, Brown \& Co., 1974.

58. Williamson, Oliver E. Corporate Control and Business Behavior: Englewood Cliffs, N.J.: Prentice-Hall, 1970.

59. -

60. Zimmerman, Martin B. "Modelling Depletion in a Mineral Industry: The Case of Coal." Bell Journal of Economics (1977)

61.

"Estimating a Policy Model of U.S. Coal supply." M.I.T. Energy Laboratory Working Paper, Cambridge, Mass., December, 1977. 